INTER NATIONAL MONETARY FUND
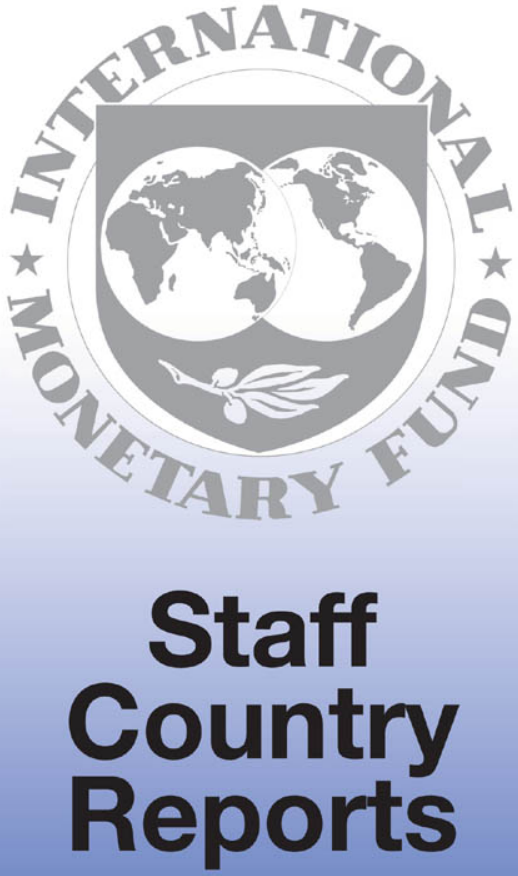
IMF Staff Country Report No. 98/122

\section{Honduras: Selected Issues}

This Selected Issues report on Honduras was prepared by a staff team of the International Monetary Fund as background documentation for the periodic consultation with this member country. As such, the views expressed in this document are those of the staff team and do not necessarily reflect the views of the Government of Honduras or the Executive Board of the IMF.

Copies of this report are available to the public from

International Monetary Fund - Publication Services

700 19th Street, N.W. - Washington, D.C. 20431

Telephone: (202) 623-7430 - Telefax: (202) 623-7201

Telex (RCA): 248331 IMF UR

Internet: publications@imf.org

Price: $\$ 15.00$ a copy

\section{International Monetary Fund \\ Washington, D.C.}


This page intentionally left blank

CInternational Monetary Fund. Not for Redistribution 


\section{INTERNATIONAL MONETARY FUND}

\section{HONDURAS}

\section{Selected Issues}

Prepared by a staff team consisting of Messrs. M. DaCosta (Head), A. Gómez-Oliver, M. Garza (all WHD), H. Juan Ramón (INS), and J. McHugh (PDR)

Approved by the Western Hemisphere Department

August 31, 1998

Contents

Page

Basic Data

4

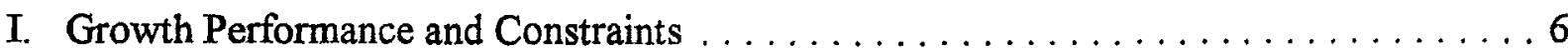

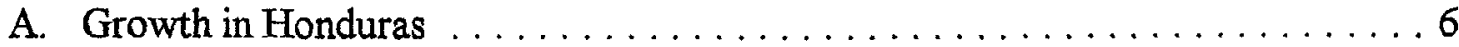

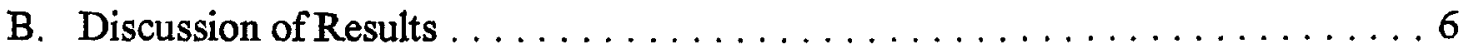

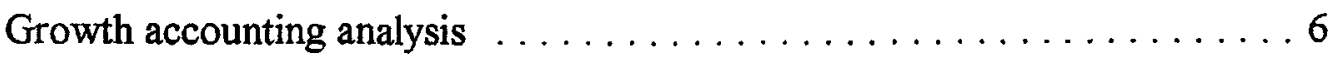

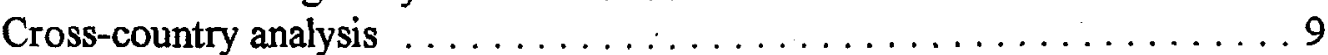

Time-series analysis of human and physical capital in Honduras $\ldots \ldots \ldots 12$

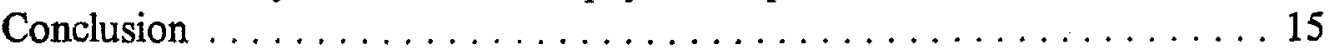

II. Key Reforms in the Public Sector during 1994-98 . . . . . . . . . . . . . . 22

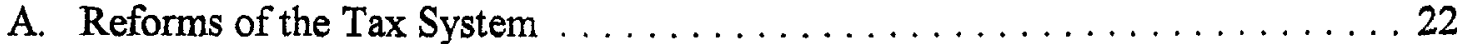

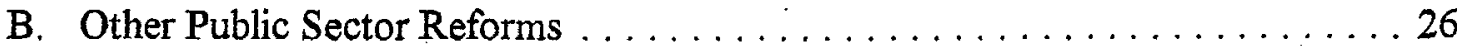

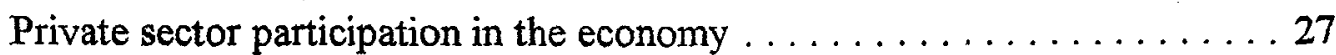

Reform of public administration ...................28

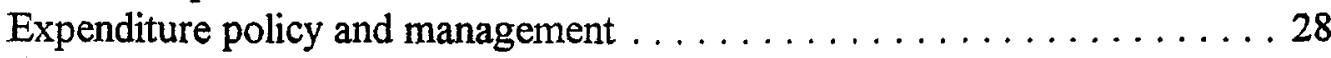

III. Recent Developments in Monetary Policy and Bank Supervision . . . . . . . . 29 29

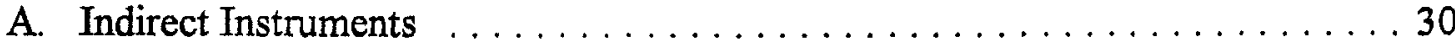

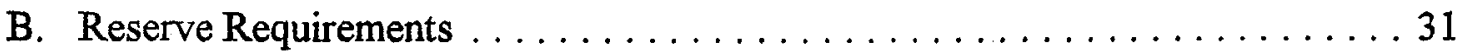

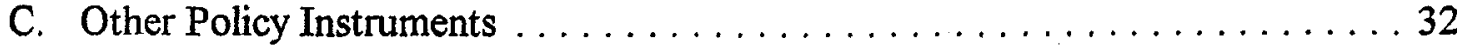
D. Banking Supervision ........................... 


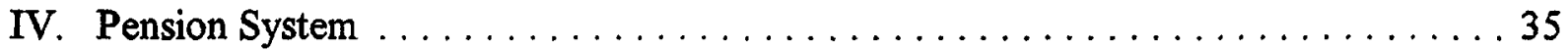

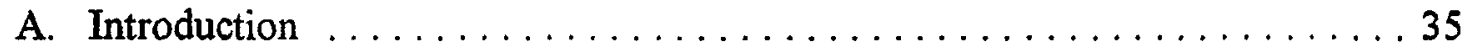

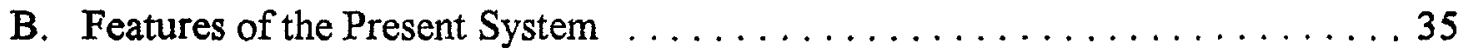

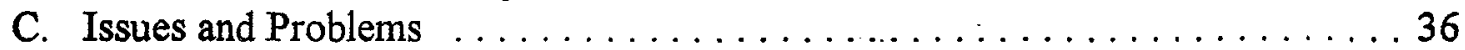

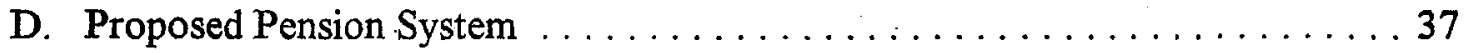

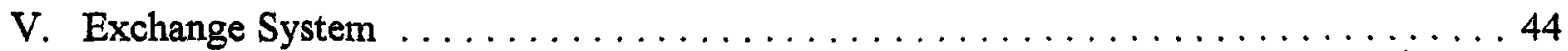

A. Antecedents to the Present Exchange System $\ldots \ldots \ldots \ldots \ldots \ldots \ldots 44$

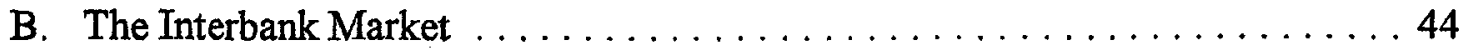

C. Features of the Present Exchange System $\ldots \ldots \ldots \ldots \ldots \ldots \ldots \ldots 45$

D. Recent Exchange Rate Developments $\ldots \ldots \ldots \ldots \ldots \ldots \ldots \ldots \ldots 46$

Text Tables

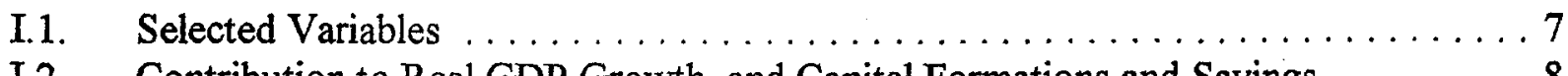

I.2. Contribution to Real GDP Growth, and Capital Formations and Savings $\ldots \ldots \ldots 8$

I.3. Country Averages of Selected Variables, $1969-95 \ldots \ldots \ldots \ldots \ldots \ldots \ldots . \ldots 10$

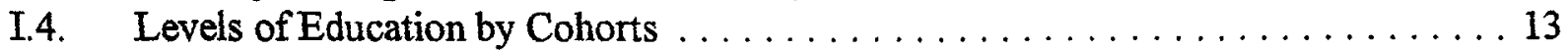

I.5. Gross Fixed Capital Formation at Constant Prices $\ldots \ldots \ldots \ldots \ldots \ldots \ldots \ldots 14$

I.6. Composition of Public Gross Fixed Capital Formation $\ldots \ldots \ldots \ldots \ldots \ldots \ldots 15$

IV.1. Main Features of the Present Pension System $\ldots \ldots \ldots \ldots \ldots \ldots \ldots \ldots 40$

IV.2. $\quad$ Contributions to the Social Security System $\ldots \ldots \ldots \ldots \ldots \ldots \ldots \ldots \ldots 2$

IV.3 Consolidated Operations of the Social Security Agencies $\ldots \ldots \ldots \ldots \ldots \ldots 42$

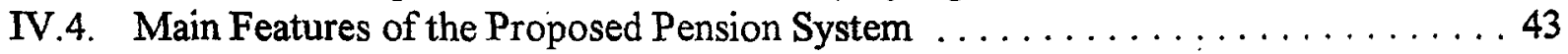

V.1. $\quad$ Foreign Exchange Operations in the Auction $\ldots \ldots \ldots \ldots \ldots \ldots \ldots \ldots \ldots 4$

V.2. Net International Reserve Coverage $\ldots \ldots \ldots \ldots \ldots \ldots \ldots \ldots \ldots$

\section{Figures}

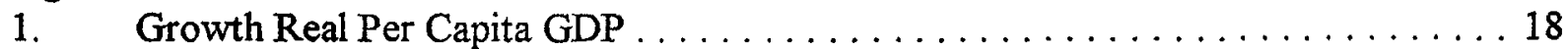

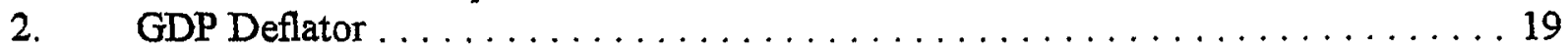

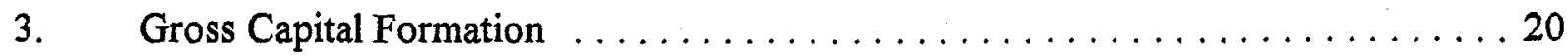

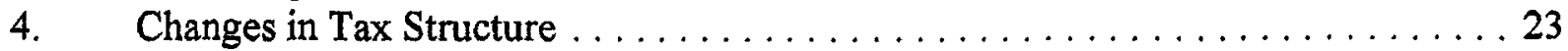

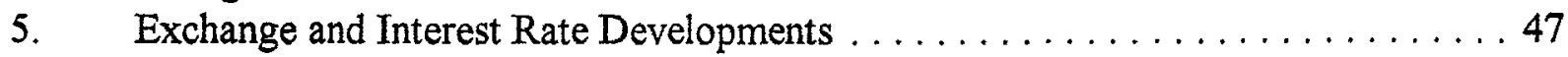

Box

Selected Changes in the Tax System, $1994-98 \ldots \ldots \ldots \ldots \ldots \ldots \ldots 25$

Statistical Appendix Tables

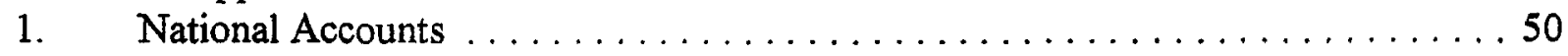

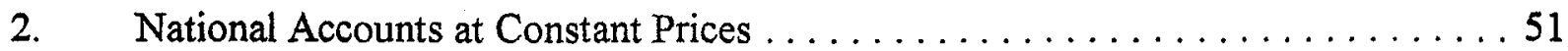

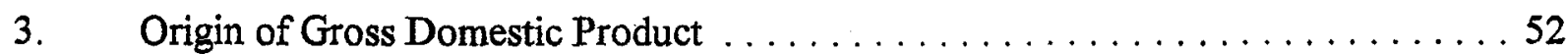

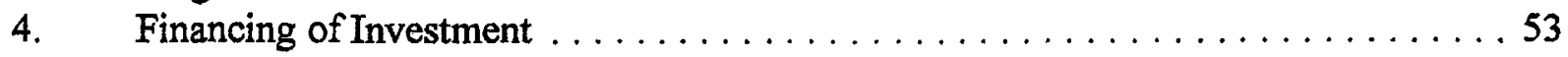


Statistical Appendix Tables (continued)

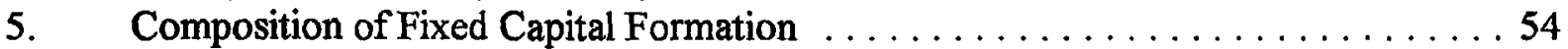

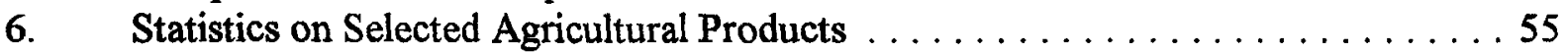

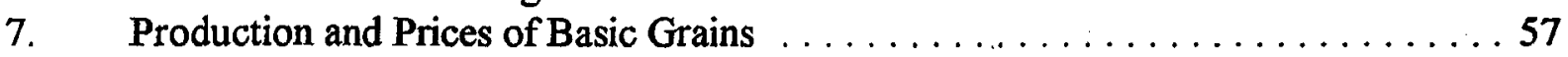

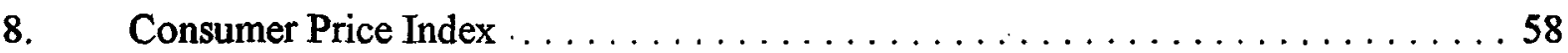

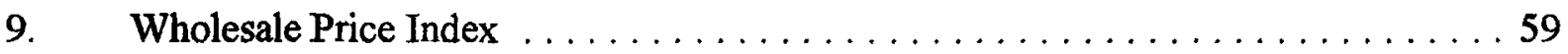

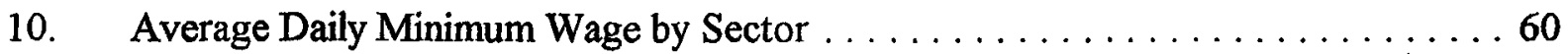

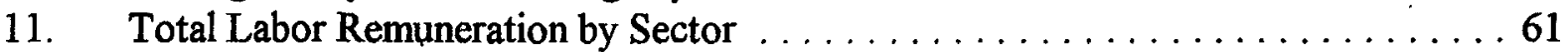

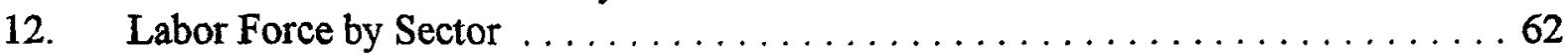

13. Consolidated Operations of the Nonfinancial Public Sector . . . . . . . . . .63

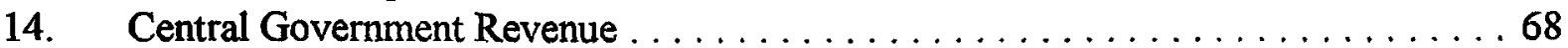

15. Operations of the Social Security Institute $\ldots \ldots \ldots \ldots \ldots \ldots$

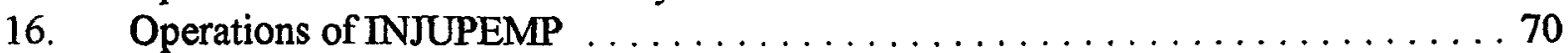

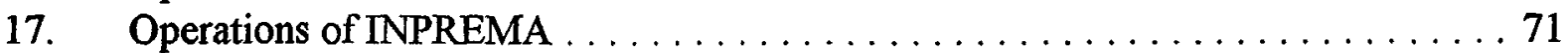

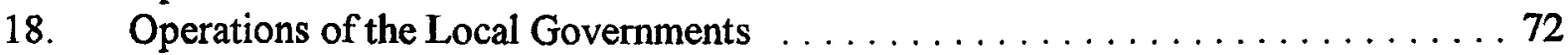

19. Operations of the Decentralized Agencies $\ldots \ldots \ldots \ldots \ldots \ldots$

20. Operations of National Enterprise of Electricity

Energy, ENEE . . . . . . . . . . . . . . . . . . . . . 74

21. Operations of the National Telecommunications

Enterprise, HONDUTEL

22. Operations of the National Autonomous Water

and Sewerage Service, SANAA . . . . . . . . . . . . . . . . 78

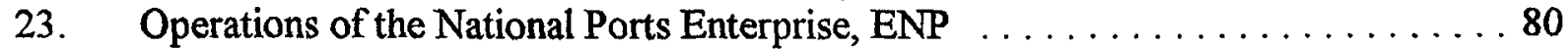

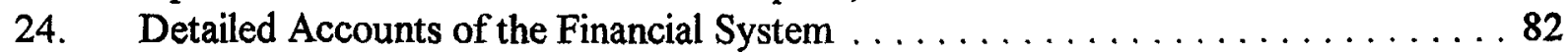

25. Destination of Banking System Credit to the Private Sector . . . . . . . 887

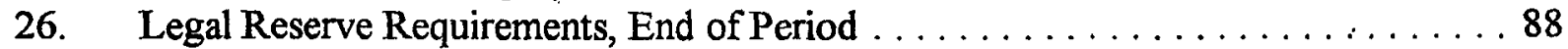

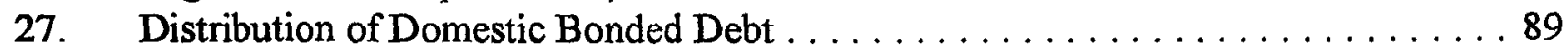

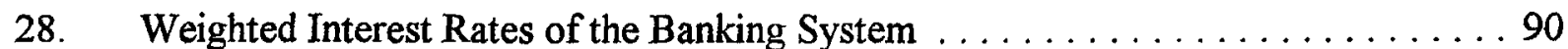

29. Balance of Payments, $1993-97 \ldots \ldots \ldots \ldots \ldots \ldots \ldots \ldots$

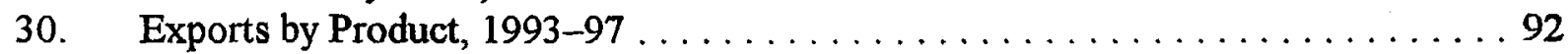

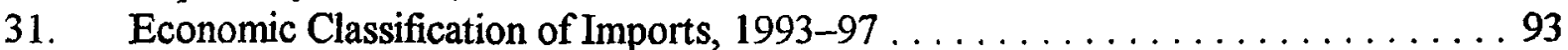

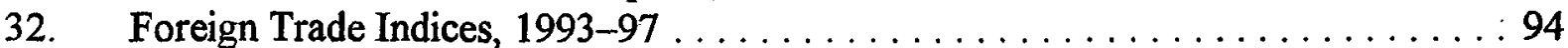

33. Distribution of Exports, f.o.b. by Destination, $1993-96 \ldots \ldots \ldots \ldots 5$

34. Distribution of Imports, c.i.f., by Origin, $1993-96 \ldots \ldots \ldots \ldots \ldots$

35. Visible Trade with the Central American Common Market, 1993-97 . . . . . . . 97

36. Medium- and Long-Term, Public and Publicly

Guaranteed External Debt and Debt Service, 1993-97 . . . . . . . . . . . 98

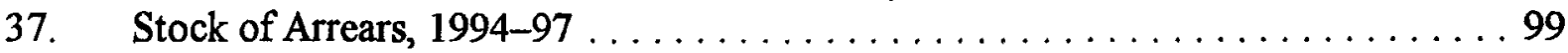

38. Nominal and Real Effective Exchange Rates, 1993-97 . . . . . . . . . . 100 


\section{Honduras: Basic Data}

\section{Social and Demographic Indicators}

$\begin{array}{lr}\text { Area (thousand sq. km) } & 113 \\ & \\ \text { Population (1997) } & 6 \\ \text { Total (million) } & 3.3 \\ \text { Annual rate of growth, 1984-97 } & 49.8 \\ \quad \text { (percent a year) } & 780 \\ \text { Density (per sq. km.) } & \\ \text { GDP per capita (US\$) } & 68 \\ & 35 \\ \text { Population characteristics (1995) } & 6 \\ \text { Life expectancy at birth (years) } & 45 \\ \text { Crude birth rate (per thousand) } & 59 \\ \text { Crude death rate (per thousand) } & \\ \text { Infant mortality (per thousand live births) } & \\ \text { Under } 5 \text { mortality rate (per thousand) } & \end{array}$

Labor force, in millions

6

3.3

49.8

80

68

35

45

59
Health

Population per physician $\quad 1,266$

Population per hospital bed $\quad 1,276$

Access to safe water

Percent of population $\quad 70$

Urban $\quad 90$

Rural $\quad 54$

Education (1993)

Enrollment rates, percent in

Primary education

Secondary education
112

33

II. Economic Indicators, 1993-97

\begin{tabular}{|c|c|c|c|c|c|}
\hline & 1993 & 1994 & 1995 & $\begin{array}{l}\text { Prel. } \\
1996\end{array}$ & $\begin{array}{r}\text { Est. } \\
1997\end{array}$ \\
\hline \multicolumn{6}{|c|}{ (In percent) } \\
\hline \multicolumn{6}{|l|}{$\begin{array}{l}\text { Annual changes in sectoral product } \\
\text { aggregates at factor cost }\end{array}$} \\
\hline GDP (in constant prices) & 6.2 & -1.5 & 4.1 & 3.7 & 4.9 \\
\hline \multicolumn{6}{|l|}{ Investmient, consumption, and savings ratio } \\
\hline Fixed capital formation/GDP ratio & 28.7 & 27.6 & 24.0 & 23.3 & 23.6 \\
\hline National savings/GDP ratio & 21.0 & 19.4 & 19.5 & 18.6 & 21.4 \\
\hline \multicolumn{6}{|c|}{ (In millions of lempiras) } \\
\hline \multicolumn{6}{|l|}{ Public sector finances } \\
\hline Noninterest revenues & 6,491 & 8,103 & 11,384 & 14,449 & 18,120 \\
\hline Noninterest expenditures & 8,276 & 7,555 & 10,412 & 13,865 & 15,828 \\
\hline Primary balance (deficit -) & $-1,785$ & 548 & 972 & 583 & 2,294 \\
\hline Overall balance (deficit -) & $-2,304$ & $-1,982$ & $-1,015$ & $-1,526$ & -933 \\
\hline \multicolumn{6}{|l|}{ Memorandum items: } \\
\hline Primary balance (percent of GDP) & -7.9 & 1.9 & 2.6 & 1.2 & 3.7 \\
\hline Overall balance (percent of GDP) & -10.2 & -6.9 & -2.7 & -3.2 & -1.5 \\
\hline \multicolumn{6}{|l|}{ Monetary accounts of the banking system } \\
\hline Liabilities to private sector & 7,752 & 10,553 & 12,741 & 16,838 & 24,138 \\
\hline Money (M-1) & 2,742 & 3,739 & 4,456 & 5,672 & 7,587 \\
\hline Quasi-money & 5,010 & 6,814 & 8,285 & 11,166 & 16,551 \\
\hline Net domestic assets & 12,447 & 16,464 & 16,853 & 18,923 & 21,138 \\
\hline Credit to the public sector & 1,023 & 803 & -110 & -690 & $-2,615$ \\
\hline Credit to the private sector & 13,815 & 7,914 & 7,420 & 12,711 & 18,690 \\
\hline \multicolumn{6}{|c|}{ (Percentage change) } \\
\hline Consumer price index (end-of-period) & 13.0 & 28.9 & 26.8 & 25.5 & 12.8 \\
\hline
\end{tabular}


Honduras: Basic Data

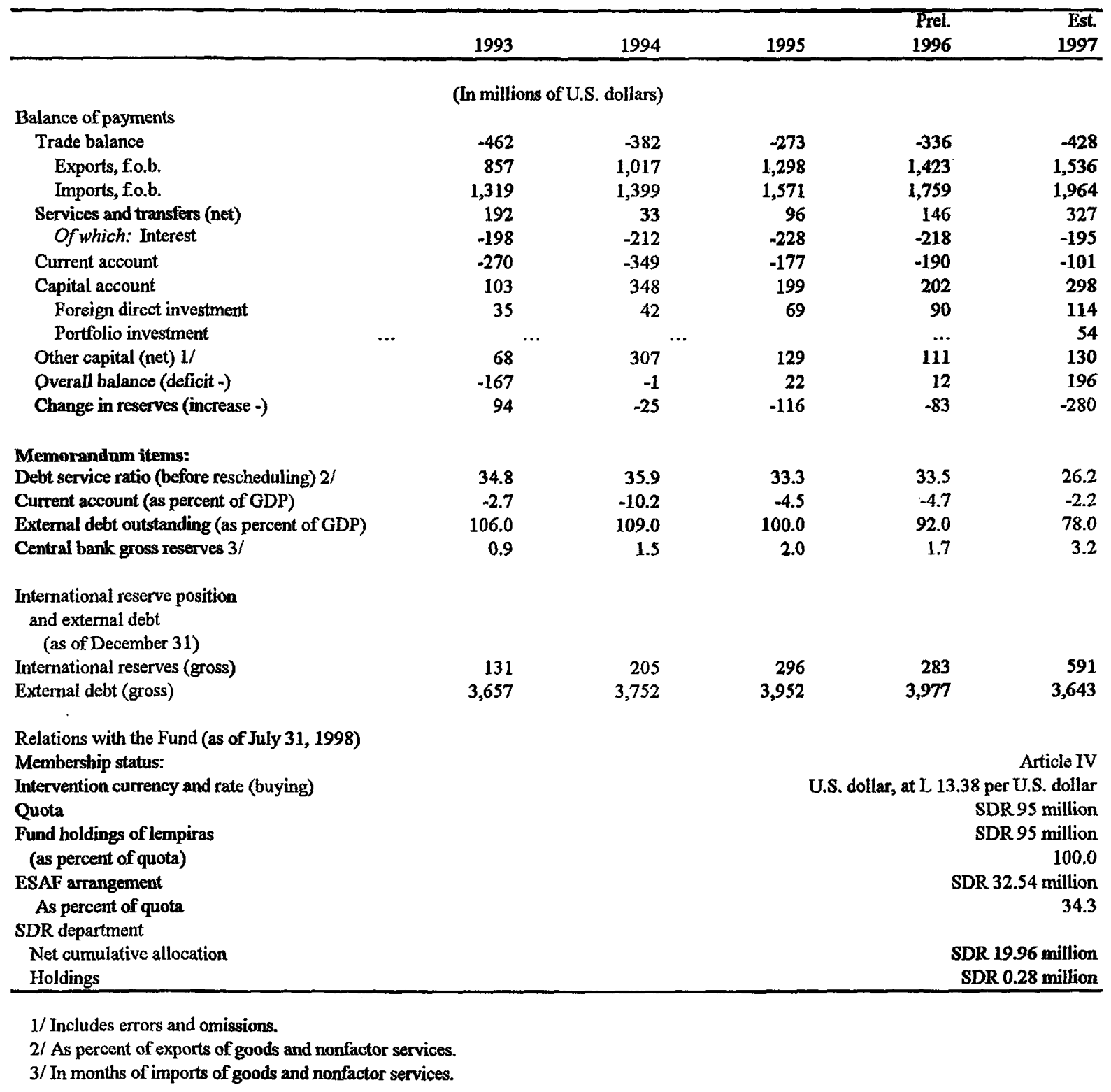




\section{GROWTH PERformanCe AND CONSTRAINTS ${ }^{1}$}

1. For more than three decades, Honduras' average annual growth in real per capita GDP has been close to zero and highly uneven, even though its total investment-to-GDP ratio has been larger than that of many high-growth-performing countries in Latin America. This chapter explores the likely causes of this weak performance. It examines the behavior of the variables relevant to sustainable growth in Honduras vis-a-vis two comparator groups: highgrowth and medium- to low-growth countries, selected from a sample of 17 Latin American countries. The first section reviews recent growth trends in Honduras, and the second section discusses the result of the analysis.

2. The findings indicate that Honduras' low growth rates in real per capita GDP reflect the influence of a combination of factors. Policy- and efficiency-related variables, exogenous shocks, and political uncertainty seem to have had less of a negative influence on growth in Honduras than they have had on the comparator groups. Instead, low growth appears to be closely related to (i) the low productivity of labor and capital, which results from relatively low levels of human capital (education, skills, and health); and (ii) the poor composition of investment and inadequate physical infrastructure.

\section{A. Growth in Honduras}

3. Since 1970, Honduras' growth performance has been consistently weak and variable despite relatively high ratios of total investment to GDP for most of the period and low inflation (see Figures 1 to 3). For the period 1970-97, the average growth rate of real per capita GDP was close to zero. Annual rates fluctuated widely (from 6 percent to -6 percent), with the greatest variability occurring during 1970-84, probably because of the various shocks to the economy, including the war with El Salvador in 1969, hurricane damage in 1974, the coffee boom of 1976, and the debt crisis in the early 1980s (Table 1).

\section{B. Discussion of Results}

\section{Growth accounting analysis}

4. The average contribution of inputs to growth in real GDP for the period 1985-97, calculated from the Solow growth accounting equation (Attachment), are shown in Table 2. The average contribution of labor to growth of 1.4 percent is explained by the average rate of growth of the labor force ( 3.3 percent) and the share of labor income in GDP (42 percent). The share of labor income in GDP is smaller than in most of the comparator countries mainly because of low labor productivity, ${ }^{2}$ which is associated with low levels of human capital.

${ }^{1}$ Prepared by V. Hugo Juan-Ramon.

${ }^{2}$ The rate of growth of the labor force is larger in Honduras than in the other countries. 
Table 1. Honduras: Selected Variables

\begin{tabular}{|c|c|c|c|c|c|c|}
\hline & \multicolumn{2}{|c|}{$1970-84$} & \multicolumn{2}{|c|}{$1985-97$} & \multicolumn{2}{|c|}{$1970-97$} \\
\hline & Average & $\overline{\text { Std. Dev. }}$ & Average & $\overline{\text { Std. Dev. }}$ & Average & $\overline{\text { Std. Dev. }}$ \\
\hline \multicolumn{7}{|c|}{ (Average annual percentage change) } \\
\hline Real GDP (at 1978 prices) & 4.0 & 4.2 & 3.5 & 2.3 & 3.8 & 3.4 \\
\hline Real GDP per capita (at 1978 prices) & 0.6 & 4.1 & 0.2 & $2: 3$ & 0.4 & 3.3 \\
\hline Population & 3.3 & 0.0 & 3.3 & 0.0 & 3.3 & 0.0 \\
\hline GDP deflator & 7.1 & 4.1 & 15.0 & 9.6 & 10.8 & 8.1 \\
\hline Consumer price index & 7.7 & 4.3 & 15.1 & 10.8 & 11.1 & 8.7 \\
\hline External terms of trade, goods & 2.0 & 14.6 & 1.5 & 12.1 & 1.8 & 13.3 \\
\hline Real effective exchange rate $1 / 2 /$ & 7.1 & 1.8 & -3.6 & 12.8 & -0.7 & 11.9 \\
\hline \multicolumn{7}{|c|}{ (Average annual percentage of GDP) } \\
\hline External current account & -7.7 & 2.9 & -4.5 & 2.4 & -6.1 & 3.2 \\
\hline Foreign direct investment & 0.1 & 0.3 & 1.2 & 0.3 & 0.6 & 0.6 \\
\hline \multicolumn{7}{|c|}{ (Average of annual stocks, in US\$ millions) } \\
\hline International reserves & 105.0 & 61.7 & 162.2 & 146.5 & 131.5 & 111.2 \\
\hline \multicolumn{7}{|c|}{ (Index, 1990 = 100) } \\
\hline Real effective exchange rate & 143.8 & 19.3 & 116.9 & 39.5 & 125.3 & 36.2 \\
\hline
\end{tabular}

Sources: Central Bank of Honduras; and IMF documents.

1/Data available for the period 1979-97.

$2 /$ Negative numbers indicate a real depreciation of the lempira. 
Table 2. Honduras: Contribution to Real GDP Growth, Capital Formation, and Savings

(Average annual percentage change)

Real GDP

Contribution of $1 /$

Labor $2 /$

Capital 3/

Residual
3.8

1.5

1.4

1.9

1.9

0.4

0.2

(Average annual percentage of GDP)

Gross capital formation at constant prices

Gross capital formation at constant prices

Public

Private

Gross domestic savings at current prices

Public

Private

External Savings
19.4

20.2

7.7

12.5

20.6

7.9

12.7

16.3

19.9

3.1

13.2

Sources: Central Bank of Honduras, IMF documents, and Fund Staff estimates.

1/ The contributions of inputs to real GDP growth are calculated using the Solow's growth accounting equation, which can be expressed as follows: $\Delta y / y=\omega_{\mathrm{L}}(\Delta \mathrm{L} / \mathrm{L})+\mathrm{F}_{\mathrm{K}}(\Delta \mathrm{K} / \mathrm{y})$, where $y$ denotes real GDP; $L$ and $K$ are stocks of labor and capital, respectively; $\omega_{L}$ is the share of labor income in GDP; and $F_{\mathrm{K}}$ is the marginal productivity of capital.

2/ Based on an average share of labor income in total GDP of 44 percent for the period 1970-97 and of 42 percent for the period 1985-97; and on an average annual growth of the labor force of 3.3 percent for both periods.

3 / Based on average real rate of return on new investment of 10 percent; and average real gross capital formation as percent of real GDP of 19.4 percent for the period 1970-97 and 18.8 percent for the period 1985-97. 
5. The average contribution of capital to growth in real GDP (1.9 percent) is explained by the average ratio of gross capital formation at constant prices to real GDP (18.8 percent), (see Table 2) and by the assumed average real rate of return on new investment (marginal productivity of capital) of 10 percent. The rate of technological progress (the residual in the Solow equation) is low, 0.2 percent. Alternatively, if one considers that a plausible rate of technological progress for Honduras lies between 1 percent and 11/2 percent, then the marginal productivity of capital (obtained as a residual) would be between 6 percent and 3 percent, indicating a poor quality of investment. The quality of investment is assessed by examining the composition of investment between the private and public sectors and between construction and machinery.

\section{Cross-country analysis}

6. Cross-country analysis is based on Table 3 , which shows average values of selected variables during 1969-95 for 17 Latin American countries, including Honduras, and for two comparator groups: high-growth countries and medium- to low-growth countries. ${ }^{3}$ Honduras, which is classified as a negative-growth country, is excluded from the comparator groups.

7. The average values of Honduras' policy-related variables-inflation, central government fiscal deficit as percent of GDP, export growth, structural change, and measures of openness and black market premium-compare favorably with the values for the comparator groups. Average inflation in Honduras at 10 percent has been much lower than that in highgrowth countries ( 75 percent) and in medium- to low-growth countries ( 277 percent). The same is true for the average black market premium, which was 18 percent for Honduras, compared with 27 percent and 56 percent for the two sample groups, respectively. Furthermore, the Honduran economy is more open. It has had higher central government fiscal surpluses, higher export growth rates, and similar indices of structural change relative to those of the two comparator groups.

8. The behavior of the external terms of trade and the real effective exchange rate have tended to foster growth. Honduras' external terms of trade improved on average 2.3 percent, compared with about 0.6 percent in the two control groups. On average, the lempira depreciated in real terms by 2.1 percent, compared with average real appreciations of the currencies of high-growth countries of 7.4 percent and average real appreciation of the currencies of medium- to low-growth countries of 2.1 percent.

9. The value of proxies for political uncertainty in Honduras relative to those of the comparator groups suggest that the degree of political uncertainty in Honduras is not hampering growth. For example, the index of government crisis for Honduras (0.1)

\footnotetext{
${ }^{3}$ The 17 countries in the sample are: Argentina, Bolivia, Brazil, Chile, Colombia, Costa Rica, Dominican Republic, Ecuador, El Salvador, Guatemala, Honduras, Mexico, Panama, Paraguay, Peru, Uruguay, and Venezuela.
} 
Table 3. Country Averages of Selected Variables, 1969-95 1/

\begin{tabular}{|c|c|c|c|c|c|c|c|c|c|c|c|c|c|c|c|c|c|}
\hline Country & YGPC & Yo & PG & TIY & PIY & GIY & SEC70 & INFL & DEFYI & $\mathbf{X G}$ & STRUC & OPEN & TTG & RERG & BMP & CRI & RIO \\
\hline \multicolumn{18}{|l|}{ High-growth countrles $2 /$} \\
\hline Brazil & 2.62 & $1,740.6$ & 2.2 & 21.2 & 13.1 & 8.1 & 9.6 & 474.6 & -1.0 & 13.6 & 0.2 & 16.8 & 0.0 & 86.1 & 34.9 & 0.3 & 0.5 \\
\hline Colombia & 2.37 & 922.8 & 2.2 & 18.3 & 12.4 & 5.9 & 9.8 & 21.9 & -1.4 & 11.8 & 0.2 & 30.0 & 2.6 & -1.4 & 9.2 & 0.4 & 0.6 \\
\hline Ecuador & 2.35 & 957.2 & 2.7 & 21.4 & 16.2 & 5.2 & 6.2 & 26.4 & -1.6 & 14.5 & 0.0 & 50.1 & 3.0 & -2.0 & 24.9 & 0.3 & 0.3 \\
\hline Dominican Republic & 2.35 & 882.7 & 2.7 & 23.4 & 16.8 & 6.6 & 12.1 & 16.8 & -0.7 & 7.7 & 0.0 & 51.1 & 1.9 & -0.7 & 37.2 & 0.1 & 0.7 \\
\hline Paraguay & 2.17 & 909.1 & 3.0 & 25.7 & 17.3 & 8.4 & 10.3 & 16.6 & -0.4 & 14.1 & 0.2 & 48.1 & -0.7 & -1.5 & 34.4 & 0.1 & 0.0 \\
\hline Chile & 2.10 & $2,175.5$ & 1.7 & 18.6 & 12.3 & 6.2 & 26.6 & 77.2 & -0.3 & 13.4 & 0.8 & 66.9 & -1.4 & -3.9 & 48.9 & 0.4 & 1.5 \\
\hline Panama & 2.08 & $1,769.7$ & 2.5 & 25.0 & 19.3 & 5.7 & 17.4 & 3.7 & -5.3 & 8.1 & 0.1 & 133.9 & -0.2 & -2.4 & 0.0 & 0.3 & 0.3 \\
\hline Uruguay & 1.77 & $2,279.9$ & 0.6 & 16.9 & 10.5 & 6.4 & 16.4 & 59.8 & -2.3 & 10.5 & 0.3 & 37.9 & 1.5 & 2.0 & 15.4 & 0.4 & 0.3 \\
\hline Costa Rica & 1.68 & $1,359.9$ & 2.7 & 25.0 & 19.0 & 6.0 & 7.6 & 18.1 & -4.0 & 11.0 & 0.3 & 71.6 & -0.1 & -1.7 & 57.5 & 0.0 & 0.1 \\
\hline Mexico & 1.29 & $2,213.0$ & 2.6 & 21.9 & 16.9 & 5.1 & 7.8 & 35.5 & -4.4 & 17.1 & 0.3 & 26.5 & 0.4 & -0.7 & 7.4 & 0.0 & 0.4 \\
\hline \multicolumn{18}{|l|}{ Medium- to low-growth countries 3 / } \\
\hline Guatemala & 0.64 & 828.8 & 3.0 & 15.2 & 10.3 & 4.9 & 3.5 & 12.1 & -2.3 & 9.5 & 0.1 & 40.7 & 0.7 & -1.3 & 15.9 & 0.4 & 0.4 \\
\hline Bolivia & 0.52 & 629.7 & 2.4 & 14.6 & 6.4 & 8.2 & 21.6 & 521.1 & -5.5 & 9.7 & 0.4 & 46.4 & 0.8 & 1.3 & 47.9 & 0.9 & 0.5 \\
\hline El Șalvador & 0.49 & 745.6 & 2.1 & 15.0 & 11.2 & 3.8 & 6.0 & 13.6 & -2.4 & 9.2 & 0.3 & 56.7 & 2.7 & 2.6 & 58.5 & 0.0 & 0.3 \\
\hline Argentina & 0.46 & $3,837.5$ & 1.5 & 19.2 & 13.5 & 5.7 & 15.3 & 352.7 & -4.6 & 12.0 & 0.2 & 17.0 & -1.2 & 4.5 & 100.9 & 0.7 & 1.4 \\
\hline Peru & 0.29 & $1,124.9$ & 2.3 & 22.7 & 17.9 & 4.8 & 13.4 & 486.4 & -3.9 & 8.9 & 0.2 & 32.3 & 0.0 & 3.5 & 55.8 & 0.4 & 0.5 \\
\hline \multicolumn{18}{|l|}{ Negative-growth countries $4 /$} \\
\hline Venezuela & -0.02 & $2,891.8$ & 2.9 & 21.7 & 8.7 & 13.0 & 11.1 & 20.9 & -1.9 & 11.5 & 0.3 & 52.2 & 6.7 & -1.8 & 42.2 & 0.2 & 0.5 \\
\hline Honduras & -0.02 & 576.2 & 3.6 & 21.4 & 11.8 & 9.6 & 3.1 & 10.0 & -6.7 & 8.3 & 0.2 & 67.1 & 2.3 & -2.1 & 18.2 & 0.1 & 0.7 \\
\hline \multicolumn{18}{|l|}{ Group averages } \\
\hline High-growth countries $2 /$ & 2.08 & $1,521.0$ & 2.3 & 21.7 & 15.4 & 6.4 & 12.4 & 75.0 & -2.1 & 12.2 & 0.2 & 53.3 & 0.7 & 7.4 & 27.0 & 0.2 & 0.5 \\
\hline Modium-to low-growth countries 3/ & 0.48 & $1,433.3$ & 2.3 & 17.3 & 11.9 & 5.5 & 12.0 & 277.2 & -3.7 & 9.9 & 0.2 & 38.6 & 0.6 & 2.1 & 55.8 & 0.5 & 0.6 \\
\hline Negative-growth countries 4/ & -0.02 & $1,734.0$ & 3.2 & 21.6 & 10.2 & 11.3 & 7.1 & 15.4 & -4.3 & 9.9 & 0.2 & 59.6 & 4.5 & -1.9 & 30.2 & 0.1 & 0.6 \\
\hline All countries & 1.36 & $1,520.3$ & 2.4 & 20.4 & 13.7 & 6.7 & 11.6 & 127.5 & -2.9 & 11.2 & 0.2 & 49.7 & 1.1 & 4.7 & 35.8 & 0.3 & 0.5 \\
\hline
\end{tabular}


Table 3. Country Averages of Selected Variables, 1969-95 5/

\begin{tabular}{|c|c|c|c|c|c|c|c|c|c|c|c|c|c|c|c|c|}
\hline Country & LIFE & ILLIT & PRIC & SEC & SECC & HIGH & HIGHC & TYR & PYR & SYR & HYR & REV & ANT & $\mathrm{CAB}$ & STR & WAR \\
\hline \multicolumn{17}{|l|}{ High-growth countries 6 ] } \\
\hline Brazil & 63.2 & 23.6 & 10.5 & 6.5 & 2.5 & 5.0 & 3.4 & 3.1 & 2.2 & 0.7 & 0.2 & 0.0 & 0.6 & 0.2 & 0.4 & 0.9 \\
\hline Colombia & 66.0 & 15.2 & 11.6 & 15.4 & 6.0 & 4.5 & 3.1 & 3.8 & 2.6 & 1.0 & 0.2 & 0.2 & 0.5 & 0.6 & 0.4 & 0.9 \\
\hline Ecuador & 64.2 & 19.3 & 21.5 & 10.5 & 4.9 & 8.8 & 6.0 & 4.6 & 3.3 & 1.0 & 0.3 & 0.3 & 0.3 & 0.4 & 0.6 & 0.1 \\
\hline Dominican Republic & 65.1 & 23.6 & 7.5 & 10.4 & 3.1 & 4.9 & 3.3 & 3.2 & 2.4 & 0.6 & 0.2 & 0.1 & 0.9 & 0.3 & 0.6 & 0.3 \\
\hline Paraguay & 66.5 & 13.7 & 14.9 & 12.5 & 5.3 & 3.6 & 2.9 & 4.3 & 3.4 & 0.8 & 0.1 & 0.0 & 0.3 & 0.0 & 0.0 & 0.0 \\
\hline Chile & 69.0 & 8.4 & 13.4 & 25.6 & 11.1 & 6.7 & 4.6 & 5.8 & 4.1 & 1.5 & 0.2 & 0.2 & 2.5 & 0.4 & 0.5 & 0.5 \\
\hline Panama & 70.3 & 14.9 & 19.8 & 21.9 & 11.2 & 9.1 & 6.2 & 5.8 & 3.9 & 1.5 & 0.3 & 0.2 & 0.9 & 0.6 & 0.3 & 0.0 \\
\hline Uruguay & 70.8 & 4.9 & 20.0 & 21.5 & 6.3 & 7.9 & 5.4 & 6.0 & 4.2 & 1.5 & 0.3 & 0.0 & 0.5 & 0.3 & 0.6 & 0.3 \\
\hline Costa Rica & 72.9 & 8.7 & 15.0 & 10.0 & 4.2 & 8.6 & 5.8 & 4.6 & 3.5 & 0.8 & 0.3 & 0.0 & 0.2 & 0.3 & 0.1 & 0.0 \\
\hline Mexico & 66.9 & 17.3 & 17.2 & 12.5 & 5.6 & 5.5 & 3.3 & 4.2 & 3.1 & 0.9 & 0.2 & 0.0 & 0.5 & 0.2 & 0.1 & 0.3 \\
\hline \multicolumn{17}{|l|}{ Medium- to low-growth countries $7 /$} \\
\hline Guatemala & 59.3 & 49.4 & 7.3 & 5.5 & 1.6 & 2.5 & 1.7 & 2.1 & 1.7 & 0.3 & 0.1 & 0.5 & 1.0 & 0.4 & 0.3 & 1.0 \\
\hline Bolivia & 53.4 & 29.4 & 8.7 & 16.2 & 6.4 & 6.3 & 4.3 & 3.9 & 2.6 & 1.2 & 0.2 & 0.8 & 1.1 & 1.2 & 1.1 & 0.5 \\
\hline El Salvador & 60.6 & 33.6 & 10.5 & 5.8 & 2.4 & 3.4 & 2.3 & 2.9 & 2.3 & 0.4 & 0.1 & 0.5 & 0.9 & 0.5 & 0.3 & 0.8 \\
\hline Argentina & 69.8 & 5.7 & 30.4 & 19.2 & 8.1 & 7.2 & 4.4 & 6.6 & 5.2 & 1.1 & 0.2 & 0.5 & 1.7 & 0.7 & 1.9 & 1.1 \\
\hline Peru & 59.5 & 19.5 & 14.3 & 16.3 & 7.9 & 9.3 & 6.3 & 4.8 & 3.3 & 1.1 & 0.3 & 0.3 & 0.6 & 0.4 & 0.8 & 0.6 \\
\hline \multicolumn{17}{|l|}{ Negative-growth countries 8 / } \\
\hline Venezuela & 68.6 & 15.0 & 10.7 & 14.7 & 6.1 & 7.2 & 4.9 & 4.2 & 3.0 & 0.9 & 0.2 & 0.1 & 0.3 & 0.5 & 0.1 & 0.3 \\
\hline Honduras & 60.6 & 35.3 & 9.0 & 7.2 & 4.4 & 2.3 & 1.6 & 2.7 & 2.2 & 0.4 & 0.1 & 0.2 & 0.9 & 0.5 & 0.2 & 0.3 \\
\hline \multicolumn{17}{|l|}{ Group averages } \\
\hline High-growth countries $6 /$ & 67.5 & 15.0 & 15.1 & 14.7 & 6.0 & 6.5 & 4.4 & 4.5 & 3.3 & 1.0 & 0.2 & 0.1 & 0.7 & 0.4 & 0.4 & 0.3 \\
\hline Medium- to low-growth countries $7 /$ & 60.5 & 27.5 & 14.3 & 12.6 & 5.3 & 5.7 & 3.8 & 4.0 & 3.0 & 0.8 & 0.2 & 0.5 & 1.0 & 0.6 & 0.9 & 0.8 \\
\hline Negative-growth countries $8 /$ & 64.6 & 25.2 & 9.8 & 11.0 & 5.2 & 4.8 & 3.2 & 3.4 & 2.6 & 0.7 & 0.2 & 0.1 & 0.6 & 0.5 & 0.1 & 0.3 \\
\hline Allomintries & 651 & 19.8 & 143 & 136 & 57 & 61 & 41 & 43 & 31 & ne & 02 & 02 & 0.8 & 05 & 05 & es \\
\hline
\end{tabular}

Source: Young and Guin-Siu (1997)

$1 /$ YGPC = Growth of real per capita GDP; Y0 = GDP in U.S. dollars/total population; PG = Population growth; TIY = Total gross capital formation/GDP; PIY = Private gross capital formation/GDP; GIY = Public gross capital formation/GDP; SEC70 = Percentage of "secondary school attained" in the total population in 1970; INFL = Percentage change in CPI;

DEFYI = Central government deficit/GDP (-if surplus); XG = Percentage change in value of exports of goods; STRUC = Structural change (dummy variable: 1 since the structural change began); OPEN = Measure of openness: (exports + imports of goods and services)/GDP; TTG = Percentage change in the external terms of trade (goods and services); RERG = Growth of real effective exchange rate; $\mathrm{BMP}=$ Black market premium; $\mathrm{CRI}=$ Government crisis; $\mathrm{RIO}=$ Riots.

2/Countries with real income per capita growth rates greater than or equal to 1 percent per year.

3 / Countries with real income per capita growth rates between 0 and 1 percent per year.

4/ Countries with negative real income per capita growth rates between 0 and minus 1 percent per year.

S/LIFE = Life expectancy at birth; ILLIT = Overall illiteracy rate, as a percentage of the population over 15 years old; PRIC = Percentage of "primary school complete" in the total population; SEC = Percentage of "secondary school attained" in the total population; SECC = Percentage of "secondary school complete" in the total population; HIGH = Percentage of "high school attained" in the total population; HIGHC = Percentage of "high school complete" in the total population; TYR = Average school years in the total population; PYR $=$ Average years of primary schooling in the total population; SYR = Average years of secondary schooling in the total population; HYR $=$ Average years of high school education in the total population; REV = Revolutions;

ANT $=$ Antigovernment demonstration; $\mathrm{CAB}=$ Major cabinet changes; $\mathrm{STR}=$ General strikes; WAR = Guerrilla warfare.

6/ Countries with real per capita growth rates greater than or equal to 1 percent per year.

$7 /$ Countries with real per capita growth rates between 0 and 1 percent per year

$8 /$ Countries with real per capita growth rates between 0 and minus 1 percent per year. 
compares favorably with those for high-growth countries $(0.2)$ and medium- to low-growth countries $(0.5)$. Other variables proxying political uncertainty ${ }^{4}$ also compare favorably with those of the comparator groups. Thus, given that Honduras' policy- and efficiency-related variables performed well relative to those in the two comparator groups, the offsetting factors driving the country's low growth rates would have to be explained by low productivity of labor and capital. This confirms the indication of low input productivity obtained in the growth accounting calculations.

10. Low labor productivity is usually attributed to low indices of human capital (education, skills, and health). Honduras has much lower indices of education than the two control groups. For example, the illiteracy rate in Honduras ( 35 percent) is higher than that of the two control groups: 15 percent and 28 percent, respectively; and the percentage of primary school completed in the total population is lower in Honduras at 9 percent, than that in the comparator groups at about 15 percent for each. ${ }^{5}$ Other indices corroborate Honduras' low level of education (see Table 3). The low education level of mature workers may be gauged by examining their school attendance, where Honduras has the worst record among all the countries in the sample. Honduras' percentage of secondary school attained in the total population in 1970 was 3 percent compared with 12 percent for each of the comparator groups.

11. Regarding investment, the quantity appears to be adequate, while the quality seems to be low. Gross capital formation as a percentage of GDP in Honduras is 21.4 percent, which is similar to that of high-growth countries ( 21.7 percent) and higher than that of medium- to low-growth countries (17.3 percent). Empirical studies have found that investment in physical infrastructure, particularly in transport and communications, and in institutional infrastructure such as more effective property rights and judicial system, fosters growth, but that public investment in other areas generally does not. Public investment as percentage of GDP in Honduras (9.6 percent) is higher than that of the two control groups: 6.4 percent and 5.5 percent, respectively.

\section{Time-series analysis of human and physical capital in Honduras}

\section{Human capital}

12. Levels of education by cohorts and for various years were compiled from surveys that the Statistics Office has conducted twice a year since 1988 (Table 4).

\footnotetext{
${ }^{4}$ These include riots, major cabinet changes, strikes, revolutions, and guerrilla warfare.

${ }^{5}$ The Pan American Health Organization (PAHO) reports that in 1995, the illiteracy rate in Honduras was 25 percent, compared with an average of 14 percent in Latin America.
} 
Table 4. Honduras: Levels of Education by Cohorts

\begin{tabular}{|c|c|c|c|}
\hline Cohorts & 1988 & 1992 & 1997 \\
\hline \multicolumn{4}{|c|}{ Panel A: persons without schooling as percentage of total persons in their cohort } \\
\hline $20-29$ & 14.6 & 10.1 & 10.7 \\
\hline $30-44$ & 23.3 & 17.9 & 16.5 \\
\hline $45-59$ & 47.5 & 38.9 & 32.3 \\
\hline \multicolumn{4}{|c|}{$\begin{array}{c}\text { Panel B: persons with either incomplete or complete primary school } \\
\text { as percentage of total persons in their cohort }\end{array}$} \\
\hline $20-29$ & 59.8 & 57.2 & 55.9 \\
\hline $30-44$ & 59.3 & 57.6 & 55.2 \\
\hline $45-59$ & 44.9 & 49.1 & 51.8 \\
\hline \multicolumn{4}{|c|}{$\begin{array}{l}\text { Panel C: persons with either incomplete or complete high-technical school } \\
\text { as percentage of total persons in their cohort }\end{array}$} \\
\hline $20-29$ & 21.3 & 26.7 & 26.7 \\
\hline $30-44$ & 13.2 & 19.1 & 22.9 \\
\hline $45-59$ & 5.8 & 9.7 & 12.8 \\
\hline
\end{tabular}

Source: Statistics Office of Honduras, "Encuesta Permanente de Hogares de Propositos Multiples," various issues.

13. These statistics reveal that the level of education of the labor force in Honduras is low, and the rate of improvement in the level of education has slowed in the last five years. Panel A shows that illiterate persons as a percentage of total population in each cohort decreased substantially from 1988 to 1992 (an advance in literacy); however, the rate of improvement subsided from 1992 to 1997. A similar concern is revealed when considering persons with either incomplete or complete primary school. Panel B shows the number of persons between the ages of 20 and 44 years with some years of primary school to have decreased relative to the total population since 1988. Also, as shown in Panel C, the number of persons with some years of high-technical school relative to the total population in each cohort has improved from the low level it reached in 1988, but the rate of progress has slowed during the last five years.

14. The health and nutrition of the population has improved in the last five years, partly because of improved delivery of these services in the poorest regions of the country. ${ }^{6}$ PAHO reports that in Honduras life expectancy at birth increased from 61 years in 1983 to 68 years in 1995 (compared with an average of 69 years in Latin America), and that infant mortality

${ }^{6}$ Honduras' central government expenditure on health as percentage of GDP averaged 2.6 percent per year during 1992-95 and fell to 2.1 percent in 1996. 
decreased from 79 per 1,000 in 1983 to 44 per 1,000 in 1995 (compared with an average of 37 per 1,000 in Latin America).

\section{Physical capital}

15. As already noted, the quantity of investment in Honduras, as measured by the ratio of gross fixed capital formation (GFCF) at current prices relative to GDP (20.2 percent on average in 1970-97) seems to be adequate when compared with high-growth-performing countries, but the quality of investment does not. Table 5 shows the ratios of GFCF at constant prices to real GDP for the private and public sectors and for construction and machinery.

Table 5. Honduras: Gross Fixed Capital Formation at Constant Prices

(In percent of real GDP, four-year averages)

\begin{tabular}{lrrrrr}
\hline & $1978-81$ & $1982-85$ & $1986-89$ & $1990-93$ & $1994-97$ \\
\hline Total GFCF & $\mathbf{2 1 . 9}$ & $\mathbf{1 6 . 5}$ & $\mathbf{1 5 . 0}$ & $\mathbf{1 9 . 7}$ & $\mathbf{2 2 . 5}$ \\
& & & & & \\
Private GFCF & 13.4 & 7.0 & 9.4 & 11.6 & $\mathbf{1 4 . 8}$ \\
Construction & 3.8 & 3.4 & 4.4 & 5.1 & 5.3 \\
Machinery & 9.6 & 3.6 & 5.0 & 6.5 & 9.5 \\
& & & & & \\
Public GFCF & 8.5 & 9.5 & 5.6 & 8.1 & 7.7 \\
Construction & 7.4 & 8.5 & 4.9 & 7.3 & 5.0 \\
Machinery & 1.2 & 1.0 & 0.7 & 0.7 & 2.7 \\
& & & & & \\
\hline
\end{tabular}

Source: Central Bank of Honduras.

16. Private GFCF as a percentage of GDP decreased in the 1980s but picked up in the early 1990 s. Private investment in machinery relative to total private investment has fallen since the late 1970s. From the data presented above, it can be inferred that private investment in machinery as a percentage of total private investment was on average 72 percent in the period 1978-81. It fell to an average of 53 percent during 1982-93 and rose again to an average of 64 percent during 1994-97. Surveys on private investment in construction conducted by the Central Bank of Honduras indicate that its composition was less prone to growth, because a larger proportion of construction was in the residential sector rather than in commercial or industrial activities.

17. Public GFCF was largely devoted to construction rather than to machinery, although in recent years the trend seems to be changing. During 1978-93, public GFCF averaged 7.9 percent of GDP, of which construction and machinery were 7 percent and 0.9 percent, respectively. During 1994-97, public GFCF was at about the same level, but construction and machinery were 5 percent and 2.7 percent of GDP, respectively. 
18. The composition of public GFCF reveals that during 1978-93 infrastructure was on average about 60 percent of total public GFCF, and fell to an average of about 34 percent in 1994-96 (Table 6). Public GFCF in infrastructure relative to total public GFCF is rather low for a country like Honduras, which has insufficient infrastructure. During 1978-93, public GFCF in industrial and transport machinery was on average about 8 percent of total public GFCF, and it increased substantially to about 31 percent in 1994-96.

Table 6. Honduras: Composition of Public Gross Fixed Capital Formation

(Four-year averages)

\begin{tabular}{lrrrrr}
\hline & $1978-81$ & $1982-85$ & $1986-89$ & $1990-93$ & $1994-96$ \\
\hline Total public GFCF & $\mathbf{1 0 0 . 0}$ & $\mathbf{1 0 0 . 0}$ & $\mathbf{1 0 0 . 0}$ & $\mathbf{1 0 0 . 0}$ & $\mathbf{1 0 0 . 0}$ \\
& $\mathbf{8 6 . 0}$ & $\mathbf{8 8 . 5}$ & $\mathbf{8 5 . 6}$ & $\mathbf{9 0 . 4}$ & $\mathbf{6 3 . 3}$ \\
$\begin{array}{l}\text { Construction } \\
\text { Infrastructure 1/ }\end{array}$ & 56.1 & 70.6 & 51.5 & 61.2 & 33.9 \\
$\begin{array}{l}\text { Other 2/ } \\
\text { Machinery }\end{array}$ & 29.9 & 17.9 & 34.1 & 29.2 & 29.4 \\
$\begin{array}{l}\text { Industrial } \\
\text { and transport }\end{array}$ & 14.0 & $\mathbf{1 1 . 5}$ & $\mathbf{1 4 . 4}$ & $\mathbf{9 . 6}$ & 36.7 \\
\begin{tabular}{l} 
Other machinery \\
\hline
\end{tabular} & 8.5 & 8.0 & 8.1 & 6.0 & 30.7 \\
& 5.5 & 3.5 & 6.3 & 3.6 & 6.0 \\
\hline
\end{tabular}

Source: Central Bank of Honduras.

1/ Water-related and sewerage projects, ports, airports and railways, electricity and telephone lines, streets, roads, and bridges.

$2 /$ Public buildings and recreational facilities.

\section{Conclusion}

19. Honduras has experienced a long period of low growth in real per capita GDP despite having a relatively high ratio of total investment to GDP. The experience of Honduras across time and in comparison with a sample of better-growth-performing countries in Latin America seems to indicate that the main constraints to growth facing Honduras are low levels of human capital and poor quality of private and public investment. The performances of policy- and efficiency-related variables, exogenous shocks, and proxies for political uncertainty seem to have had less of a negative influence on growth in Honduras than they have had in other countries in Latin America. Instead constrains on per capita growth in Honduras seem to have been caused more by the poor quality of labor and investments.

20. Higher labor productivity is crucial for generating sustainable per capita growth. But improving labor productivity is a long-term endeavor as it takes time and resources to have a healthier, more educated, and skillful labor force. In addition to public investment in education and health, having a more flexible labor market also contributes to improving the skills of the 
labor force, as it reduces the cost to private firms of investing in employee training. Increasing the stock and productivity of capital is also crucial to growth. This requires (i) facilitating foreign (and domestic) investments; (ii) modernizing the concession law; (iii) improving the judicial system; (iv) speeding up privatizations in communication, electricity, the pension system, ports, and airports; (v) upgrading prudential regulations and tightening supervision of the financial sector; (vi) further opening the economy; and (vii) eliminating remaining regulations to internal trade. 


\section{References}

Central Bank of Honduras, Reports of the National Account Division, various issues.

Statistics Office of Honduras, "Encuesta Permanente de Hogares de Propositos Multiples," various issues.

International Monetary Fund, Mexico: 1997 Recent Economic Developments (SM/97/211). Chapter V ("Determinants of Growth") prepared by Philip Young and Maria Teresa Guin-Siu.

Pan American Health Organization, Basic Indicators 1996, Washington, D.C., 1996. 
Figure 1. Honduras: Growth Real Per Capita GDP

(In percent)

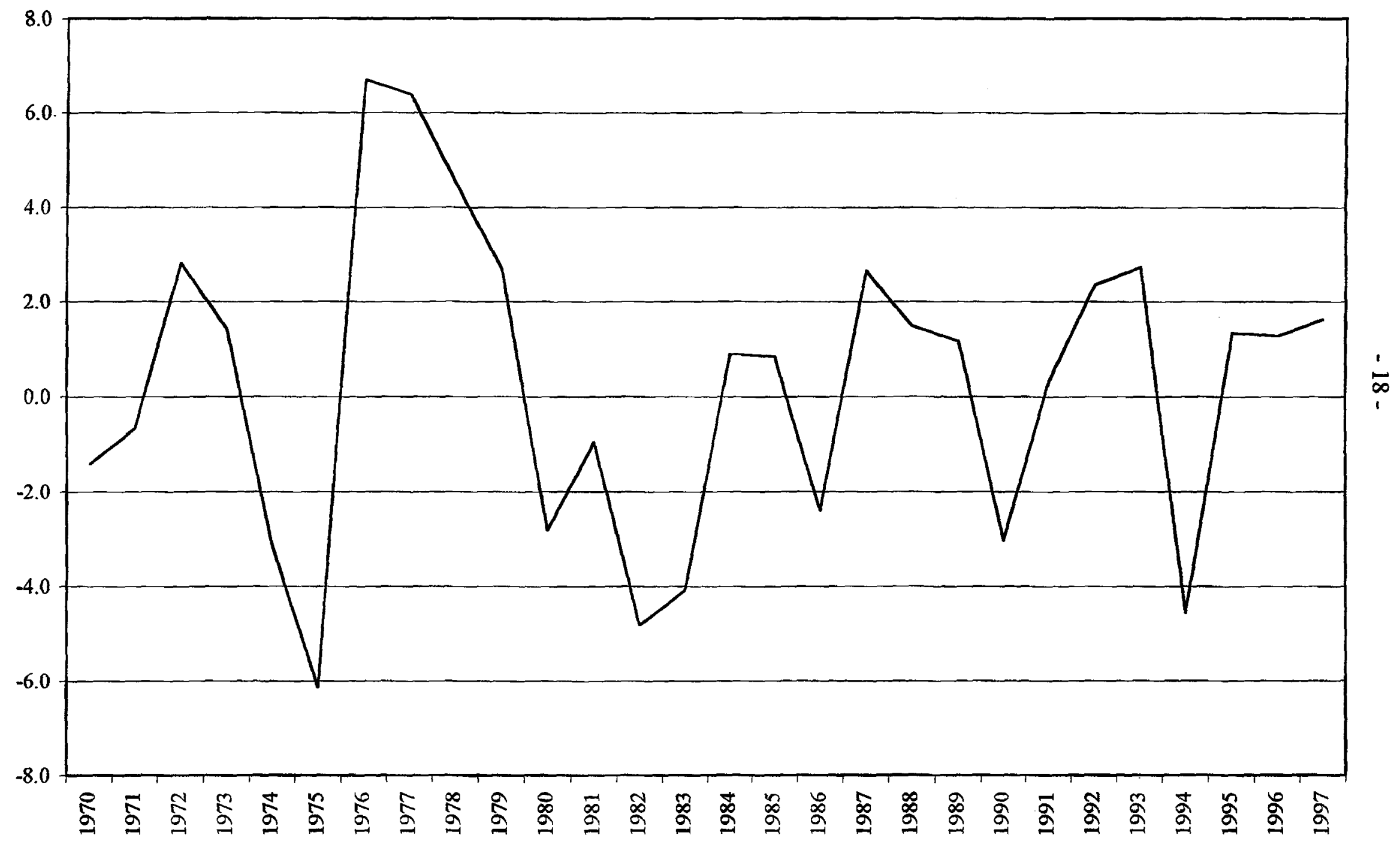


Figure 2. Honduras: GDP Deflator

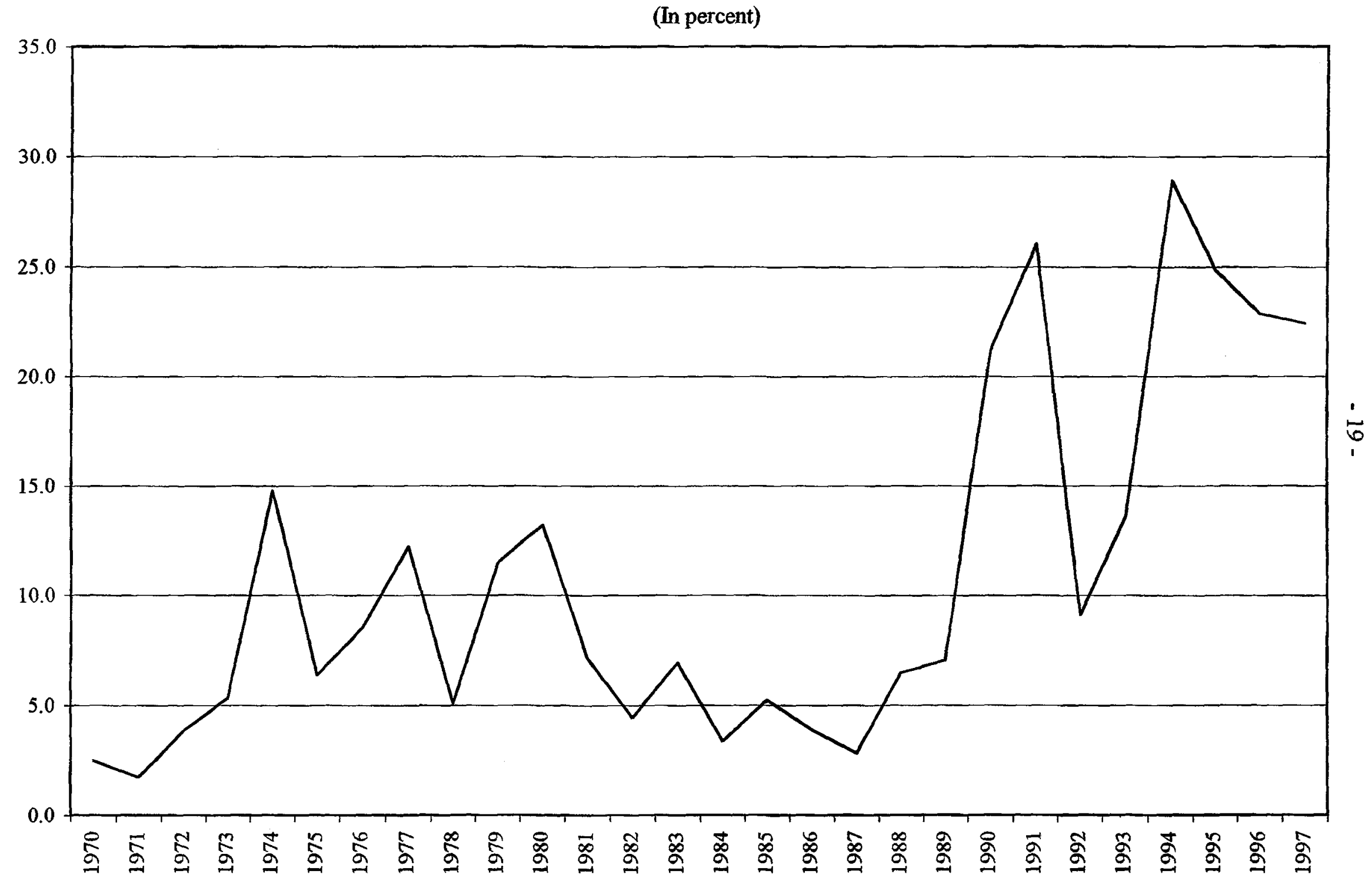


Figure 3. Honduras: Gross Capital Formation

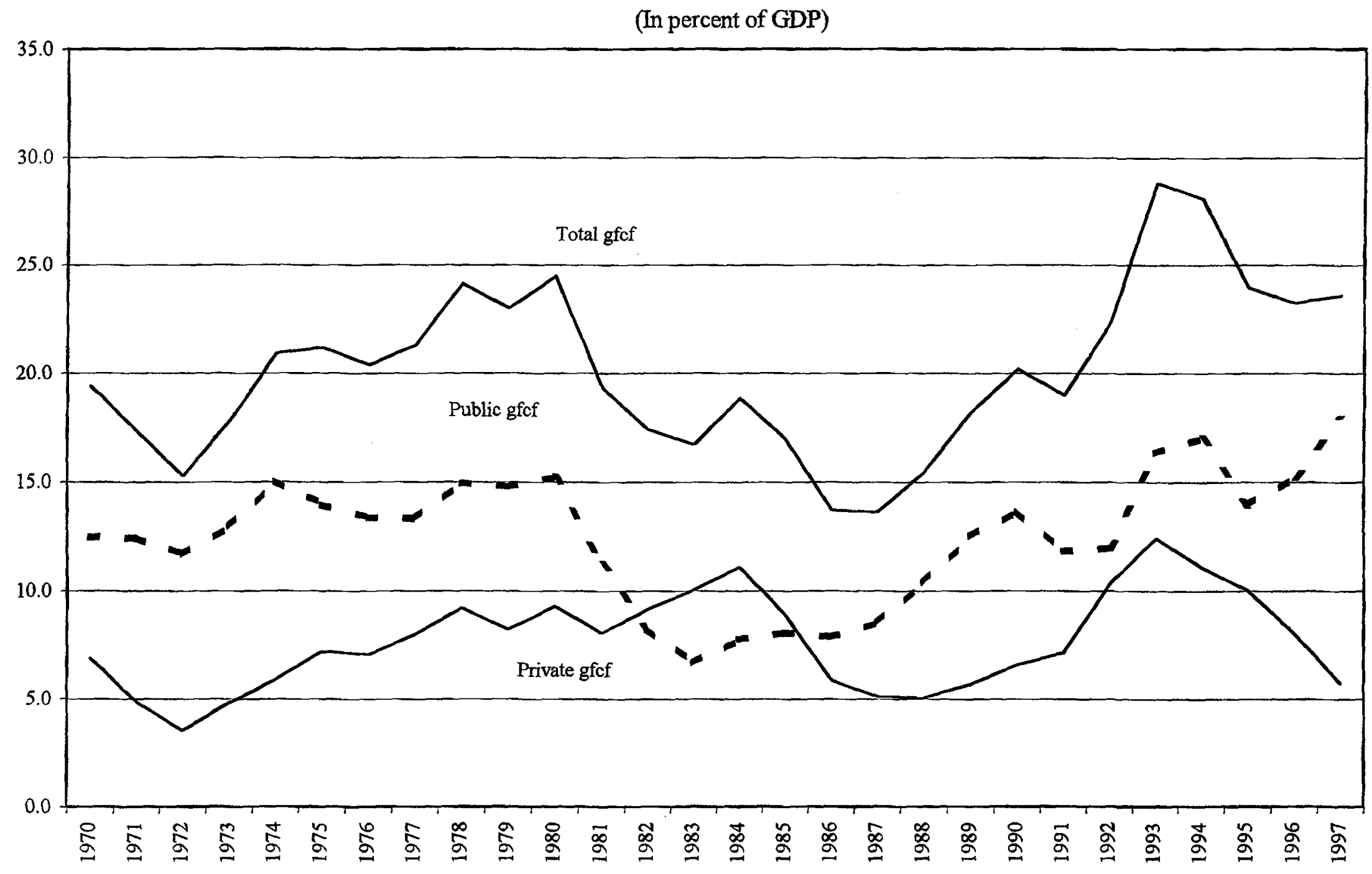




\section{Growth Accounting Equation}

The Solow neoclassical growth accounting equation used in the analysis may be specified as follows:

$$
\frac{\Delta y}{y}=\omega_{L} \frac{\Delta L}{L}+F_{K} \frac{\Delta K}{y}+\text { Technological progress }
$$

where $\Delta$ is the absolute change operator; $y$ denotes real GDP; $L$ and $K$ are stocks of labor and capital; $\Delta K$ stands for gross fixed capital formation; $\omega_{L}$ is the share of labor income in GDP; and $F_{K}$ is the marginal productivity of capital. A more general approach to determine growth, which is based on a cross-section of countries over a specified period, can be formulated as follows:

$$
\begin{gathered}
Y G P C=\varphi_{0} \ln Y_{0}+\varphi_{1} \ln P G+\varphi_{2} \ln T I Y+\varphi_{3} \ln H C I+\varphi_{4} I N F L+ \\
+\varphi_{5} D E F Y I+\varphi_{6} X G+\varphi_{7} S T R U C+\varphi_{8} O P E N+\varphi_{9} T T G+ \\
+\varphi_{10} R E R G+\varphi_{11} B M P+\varphi_{12} P V+\text { disturbance terms }+ \text { constant }
\end{gathered}
$$

where:

ln

$=$ natural logarithm

YGPC = growth of real per capita GDP

$Y_{0} \quad=$ GDP in U.S. dollar per capita

$P G \quad=$ population growth

$T I Y=$ total gross fixed capital formation to GDP

HCI = a measure of human capital

INFL = percentage change in consumer price index

DEFYI = central government deficit to GDP

$X G \quad=$ growth in the value exports of goods

STRUC = dummy variable that takes unitary value since the structural change began

OPEN = a measure of openness

TTG = percentage change in the external terms of trade

$R E R G \quad=$ percentage change in the real effective exchange rate

$B M P \quad$ = a measure of black market premium

$P V$

$=$ proxy for political variables. 


\section{Key REFORMS IN THE PUBLIC SECTOR DURING 1994-987}

21. Public sector reforms in Honduras during 1994-98 have focused mainly on improving the structure and efficiency of the tax system, and substantial progress has been made in this area. Some advances were made in efforts to reduce the size of the public sector and increase its efficiency, but in the public enterprises, there is an urgent need for additional investment to satisfy the unmet demand for telecommunications and electricity services, and to upgrade the quality of service in these sectors to meet the increasingly sophisticated demands by users. However, long-standing proposals to increase the role of the private sector in these activities are yet to be implemented.

\section{A. Reforms of the Tax System}

22. Revenue reforms implemented during 1994-98 aimed mainly at changing the structure of the tax system by reducing its traditional reliance on foreign trade and income taxes and shifting its focus toward indirect taxes. This shift was predicated on the need to move Honduras' tax structure closer in line with international and regional trends; increase competitiveness; reduce distortions against saving, investment, and exports; and raise the efficiency of revenue administration.

23. The reforms appear to have largely achieved their objectives. By end-June 1998, the tax structure had changed markedly (Figure 4). ${ }^{8}$ The top marginal income tax rate had been lowered sharply and commitments made for a further reduction in 1999; import tariffs had been reduced to levels prevailing in other Central American countries and remaining export taxes were being phased out; the sales tax rate had been raised to a level more in line with those of neighboring countries; and progress had been made in strengthening revenue administration. As to overall performance, over the period 1994-97, central government revenue increased from 16 percent of GDP to 17 percent, and the end-1997 ratio compared well with the combined ratio for Latin American countries.

24. Regarding income taxes, the reduction in the ratio to total tax receipts stemmed mainly from (i) the lowering of tax rates (the top marginal tax rate on personal and corporate incomes) fell from 42 percent to 30 percent in $1998,{ }^{9}$ and the surcharges on profits were eliminated, ${ }^{10}$ and

${ }^{7}$ Prepared by Antonio Gómez-Oliver.

${ }^{8}$ At the end of 1997 , income and trade-related taxes comprised 24 percent and 21 percent of total government revenue, respectively, compared with 28 percent and 27 percent at end1993. Over the same period, indirect taxes (other than trade taxes) increased to 49 percent of revenue from 36 percent.

${ }^{9}$ The marginal rate is scheduled to decline further to 25 percent in 1999 . The tax rate on 
Figure 4. Honduras

CHANGES IN THE TAX STRUCTURE

(In percent of GDP)

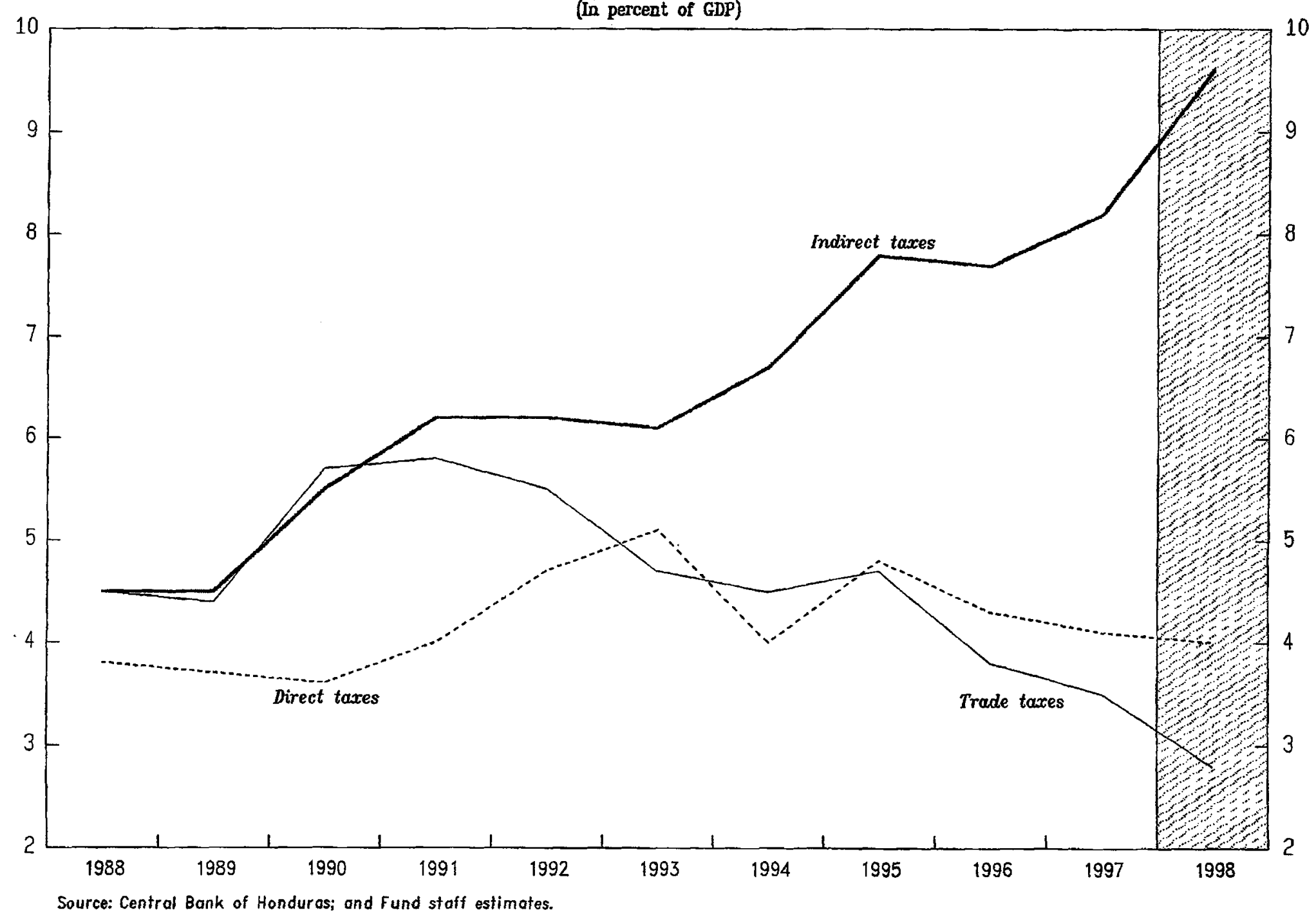

Source: Central Bank of Honduras; and Fund staff estimates. 
(ii) raising the minimum income subject to taxation. The decline in the share of trade taxes in total revenue was achieved also through a lowering of tax rates as part of an agreement among Central American countries to harmonize their import tariff regime by end-1999. ${ }^{11}$ In Honduras, import tariffs on capital goods and raw materials were lowered from 5 percent in 1996 to 1 percent in 1998, and those on most consumer goods were reduced from 20 percent to 19 percent. Also, import surcharges and most export taxes (on coffee, meat, and sugar) were eliminated. ${ }^{12}$ Reduced reliance on income and trade taxes was compensated mainly through increased collections from the petroleum derivatives and sales taxes. ${ }^{13}$ Regarding the former, the most recent change has been to set the tax in terms of U.S. dollars (payable in lempiras at the current exchange rate). ${ }^{14}$ The base of the sales tax was widened to include services in 1995 , and the sales tax rate ${ }^{15}$ was raised from 7 percent to 12 percent in June 1998 (Box). ${ }^{16}$

25. Important improvements in revenue administration have been made largely through the introduction of a tax code in 1997 (see Box), and reforms in the customs area. The key improvements in the tax code comprised the establishment of a clear legal framework for defining and strengthening penalties for tax evasion and fraud, and for collecting tax arrears that resulted in less discretion in the application of tax rules. The code characterizes tax evasion, tax fraud, and

\section{${ }^{9}$ (...continued)}

profits below $\mathrm{L} 200,000$ is 15 percent.

${ }^{10}$ The rates of surcharge were 5 percent for profits above $\mathrm{L} 500,000$ and 10 percent for profits above $\mathrm{L} 1$ million.

${ }^{11}$ The objectives of the regional agreement are to eliminate tariffs on imports of raw materials and of capital goods, and lower tariffs on consumer goods to 15 percent.

${ }^{12}$ The remaining export tax (on bananas) was reduced in 1998 and is scheduled to be eliminated by the year 2000 .

${ }^{13}$ At end-1997, these taxes accounted for 10 percent and 22 percent, respectively, of government revenue, compared with 0 percent and 18 percent at end-1993.

${ }^{14}$ The specific taxes are as follows: super gasoline-US $\$ 0.80$ per gallon; regular gasolineUS $\$ 0.76$ per gallon; diesel-US\$0.20 per gallon; and fuel oil-US\$0.08 per gallon.

${ }^{15}$ This tax is levied at each stage of production in a noncumulative way allowing a credit for the tax paid in previous stages of production. Investment goods are exempted from this tax and exports are levied at a zero rate.

${ }^{16}$ The sales tax rate for alcoholic beverages and tobacco products was raised from 10 percent to 15 percent. 


\section{Box. Selected Changes in the Tax System, 1994-98}

I. Income tax

The introduction for a period of two years of a 5 percent export tax and a minimum income tax of 10 percent on the windfall profits of coffee producers.

The introduction of a 1 percent on the gross assets of firms.

An increase in the minimum taxable income from $\mathrm{L} 20,000$ to $\mathrm{L} 50,000$ per year.

A reduction in the personal income tax rates from a maximum of 42 percent to a maximum of 30 percent.

An increase in the minimum taxable income from $\mathrm{L} 50,000$ to $\mathrm{L} 70,000$ in 1998 and to L 90,000 in 1999.

A reduction in the main corporate income tax rate from 35 percent to 30 percent in 1998 and to 25 percent in 1999 . The two surcharges were eliminated.

A gradual elimination of the Net Assets Tax from 1 percent in 1998 to 0 in 2002.

II. Trade taxes

a. Imports

The elimination of a 10 percent import surcharge and the reduction of a customs service charge on all imports from 5 to 3 percent.

The reduction of the import tax on capital goods from 5 percent to 3 percent, and to 1 percent as of January $1,1997$.

An increase in the import tax on petroleum derivatives from L 2.00 to L 7.00 per gallon of gasoline and from L 0.50 to L 2.10 per gallon of diesel.

The reduction in the customs service charge from 3 percent to 1.5 percent, as of December, 1996, and to 0.5 percent as of April 1, 1997.

The import tax on raw materials was reduced from 5 percent to 3 percent, as of June 1, 1997, and to 1 percent as of December, 1997.

The import tax on most consumption goods was reduced from 20 percent to 19 percent as of December, 1997. 1/

Elimination of the 0.5 percent customs service charge on imports of raw materials and capital goods, starting on June 1, 1998.

b. Exports

The elimination as of January 1, 1995 of a 1 percent surcharge in the value of all exports. (It was estimated that the three measures implied a revenue loss of 0.7 percent of GDP.)

The introduction for a period of two years of a 5 percent export tax.

The elimination of the 5 percent export tax part on the windfall gains on coffee.

The elimination of the 10 percent income-tax on windfall gains on coffee.

The elimination of the exports tax on shrimp and meat.

An elimination of export taxes on most products (shrimp, lobster, meat, sugar, etc.) And a gradual reduction in the tax on bananas' exports to US\$0.18 per box in 1998 to US $\$ 0.04$ per box in 2000 .

III. Other indirect taxes

Sales tax

The expansion in the base of the sales (value added) tax to include services.

An increase in the sales (VAT) rate from 7 percent to 12 percent starting in June 1998.

1/Excluding textiles. 
smuggling as crimes that carry fines or penal sanctions that are related to the size of the crime. ${ }^{17}$ There also are provisions in the code for (i) sanctions for recidivism that may include confiscation or seizure of merchandise, temporary closure of business, and the loss of concessions and exemptions; and (ii) permitting the tax office to estimate tax liabilities through the use of third party sources of information. In the customs area, the introduction in August 1997 of the Simplified Automatic Customs System ${ }^{18}$ permitted faster processing of customs requirements and the elimination of discretion exercised by the customs agents over customs valuation and taxation. Partly reflecting these changes, customs revenue rose on average by about 30 percent in the second half of $1997,{ }^{19}$ compared with collections in the same period in 1996.

26. Despite the progress made, a number of issues in tax policy and revenue administration remain to be addressed. These include the need to (i) reduce tax evasion and the scope of tax exemptions; (ii) strengthen further the tax office by additional training to upgrade the skills of tax collectors; and (iii) pay competitive salaries to attract and retain competent tax administrators. Regarding evasion, estimates done 3-4 years ago indicated that it accounted for about 35-40 percent of actual income tax collections. While recent improvements in tax administration (including the 1997 Tax Code) have probably led to a decline in this ratio, it remains high. Exemptions from income, trade, and the sales tax recently expanded in April, when these exemptions-previously available only to exporters in the free trade zones-were extended to all exporters. ${ }^{20}$ Recent decisions by the government have also resulted in exemptions from import taxes to private generators of electricity, and from income taxes in the case of exporters. Estimates of the annual fiscal loss from these actions range from $0.3-0.7$ percent of GDP.

\section{B. Other Public Sector Reforms}

27. The government's Public Sector Modernization Program (PSMP) that was initiated in 1996 with support from the World Bank and the IDB aims at (i) promoting greater private sector participation in the economy and reducing the role of the state to regulation and consumer protection; and (ii) improving public administration through greater efficiency,

\footnotetext{
${ }^{17}$ The penalties range from 1 day to 20 years of prison for smuggling, tax fraud, and tax evasion.
}

${ }^{18} \mathrm{~A}$ system created by the UN which is already being applied in other countries like Mexico. The system was introduced in Honduras with technical and financial assistance from IADB.

${ }^{19}$ The increases in the main customs (La Mesa, in San Pedro Sula and Toncontin), in Tegucigalpa were above 35 percent with respect to revenue during the same period in 1996.

${ }^{20}$ Exemptions from the sales tax include goods comprising the basic consumer basket and certain public services, such as electricity. 
transparency, and accountability, and steps to curtail current expenditure. A main objective of the reform of public administration is to reduce employment associated with nonpriority programs, and revise the salary structure by decompressing it and giving greater scope for increased salaries for technical and specialist staff. ${ }^{21}$

\section{Private sector participation in the economy}

28. Since 1990, governments have recognized the need for increased private sector participation in the economy, especially in the provision of basic services (telephones, electricity, and other infrastructure). The following are the main initiatives currently being pursued by the Flores administration:

- In the telecommunications sector, preparations are being made for the sale to the private sector of shares in the company that will be granted a long-term concession to provide all basic telephone services. In this regard, approval by congress of a proposal to launch the process leading toward the sale of shares is expected shortly. Also, the new regulatory body for the telecommunications sector is studying the adequacy of existing tariffs.

- In the electricity sector, the private sector already participates in generation, and a single new regulatory body has been set up. The next steps currently being worked on include putting into place a tariff system based on costs and initial steps toward separating the finances and administration of the 3-4 regional distribution companies that will be formed out of the current, single state-owned entity, in anticipation of the invitation for bidding for those companies. ${ }^{22}$

- In civil aviation, international advisory firms have started work on (i) the preparation of a strategy for awarding management and concession contracts to the private sector for the operation and navigation services of all the country's main airports; and (ii) an assessment of the financial condition of the airports.

- Regarding other sectors, the reform program aims, inter alia, at ensuring an efficient road transportation network by continuing the system of long-term maintenance contracts with private firms; and implementing a road fund (Fondo Vial) to finance road maintenance-funded through proceeds from toll roads.

\footnotetext{
${ }^{21}$ Estimates indicate that the ratio of compression (highest salary as a multiple of lowest salary) increased from about 5 to 1 in 1994 to 7 to 1 in 1997.
}

${ }^{22}$ In recent years electricity distribution has been plagued by inefficiency, and has experienced losses equivalent to about 27 percent of generation. 


\section{Reform of public administration}

29. Restructuring of the key ministries and departments has focused on improving the organization of the public sector by eliminating obsolete activities and functional duplication. Some progress has been made in transferring some activities to the private sector (for example, agricultural research), reducing the number of institutions (such as the planning office), and eliminating vacancies. Also, these efforts have led to a substantial reduction of permanent employment since 1993. The absence of accurate coverage and accounting for positions makes it difficult to reach firm conclusions about progress in this area. ${ }^{23}$ However, it is estimated that between end-1994 and end-1997 public sector employment (excluding personnel in the health and education areas) fell by 13.4 percent-equivalent to 6,050 positions (14.3 percent in the central government and 12.3 percent in the rest of the nonfinancial public sector). ${ }^{24}$ An audit to update statistics on employment, skills, and positions in the public sector is currently being carried out with World Bank assistance, with a view toward identifying other areas of duplication. The audit will also set the basis for a comprehensive human resources policy in the public sector aimed at improving the incentive structure, reclassifying posts in order to allocate higher salaries to scarce skills, and restoring the differential between the lowest and highest salaries. ${ }^{25}$

\section{Expenditure policy and management}

30. At about 26 percent of GDP, noninterest expenditure of the public sector in Honduras is high relative to the Latin American region. Efforts to rationalize spending in the central government have been hampered mainly by the high degree of inflexibility caused by the earmarking of revenues for specific spending purposes; the substantial, across-the-board wage awards in recent years that have offset the saving achieved through the reduction in employment noted above; and the still large proportion of the budget allocated to debt service. These factors have reduced the scope for discretionary expenditure policy.

31. On earmarking, various rules have developed, some of which are incorporated in the constitution, that allocate fixed amounts of government revenue to specific agencies or purposes. For example, transfers are earmarked to the national university (6 percent of total revenue), the supreme court ( 3 percent), municipalities ( 5 percent), and the tax administration (DEI) (2.5 percent). Most other transfers and subsidies which are not earmarked (including

\footnotetext{
${ }^{23} \mathrm{An}$ audit of positions in the central government is currently being carried out.
${ }^{24} \mathrm{Part}$ of that reduction was offset by an increase by about 1,700 positions in the ministry of education.

${ }^{25} \mathrm{~A} 1994$ report by the World Bank noted that in the central government administration about 30 percent of employees had, at most, a primary education, and that professional and technical staff represented only 20 percent of employees. 
those to producers of coffee, basic grains, and cement) were eliminated in 1994-95. However, others have remained or increased, such as those for middle-income electricity consumers and for bus owners. Inadequate tariff policies and operational inefficiencies in the state electricity company (ENEE) have also led to the need for government support to ENEE equivalent to about 1 percent of GDP a year.

32. The wage bill of the central government as a proportion of total primary expenditure increased from 28 percent in 1993 to 37 percent in $1997 .{ }^{26}$ Over the same period, the proportion of spending on goods and services and current transfers rose from 29 percent to 35 percent. That of capital expenditure fell from 40 percent to 24 percent, or from 5 percent of GDP to 4 percent of GDP. Toward the end of 1997, the basis was laid for a further expansion in the wage bill as a result of an agreement by the government to wage awards to physicians and teachers averaging 30 percent a year for three years beginning 1998.

33. The government recognizes that a successful fiscal policy will depend on tackling the rigidities that derive from earmarking, introducing a revised wage policy based more closely on performance, and improved financial management through greater attention to establishing expenditure priorities, centralized cash management in a single account at the central bank, and better control over the flow of spending during the fiscal year. Regarding earmarking, discussions are taking place with the university authorities with a view to improving resource use, and it is expected that tariff adjustments for electricity will reduce the scope of subsidies. As noted above, on wages, the technical assistance being provided by the World Bank will help to rationalize employment and salaries beginning in 1999. In the area of financial management, the government has begun to implement the recommendations of the Fund and the World Bank technical assistance. A single cash account has been established-with efforts being made to include all transactions under that account, and under the integrated financial administration system (SIAFI) the ministry of finance is exercising better control over budget execution and adherence to spending limits.

\section{RECENT DEVELOPMENTS IN MONETARY POLICY AND BANK SUPERVISION ${ }^{27}$}

34. Throughout the 1990s, the government's main monetary policy objective has been to achieve rates of inflation that were much lower than the levels-ranging from 12-30 percent - that have prevailed during 1990-96. This objective was included in virtually all of the authorities' economic programs, and was to have been achieved through reducing the fiscal deficits, greater reliance on open market operations, liberalizing interest rates, and ensuring compliance with reserve requirements. In the event, despite progress in reducing fiscal

\footnotetext{
${ }^{26}$ The estimate for 1998 is 40 percent.

${ }^{27}$ Prepared by Carlos Piñerúa.
} 
imbalances (the combined fiscal deficit narrowed from 9 percent of GDP in 1993 to 4 percent in 1996), inflation at end-1996 stood at 26 percent. A tightening in monetary for most of 1997 as well as a real appreciation of the exchange rate and a more restrictive fiscal policy during that year led to a marked decline in inflation to 13 percent at end-December. The inflation rate stood at 14 percent at end-July 1998. This section summarizes recent key developments relating to monetary policy instruments.

\section{A. Indirect Instruments}

35. The central bank conducts open market operations through periodic auctions of its own (90 day) paper (certificados de absorbción monetaria (CAMs)), as well as treasury bonds of maturities ranging from 60 days to 1 year. Until early 1997, the participants in the auction presented their bids (quantity demanded and price offered) prior to the time of the auction, and the central bank pre-announced the cut-off rate--which was the same for CAMs and bonds, and the quantity to be auctioned. As a result, and due to the central bank's failure to adjust the cut-off rate to reflect seasonal changes in monetary conditions, market participants-and not the central bank-determined the amount that was effectively auctioned, which was at times well below the amount indicated in the bank's monetary program. In 1996, for example, the bank had only limited success in placing its own paper; and the stock of CAMs issued (excluding those held to meet reserve requirements) increased only by about $\mathrm{L} 150$ million. ${ }^{28}$

36. In January 1997, the Central Bank of Honduras (CBH) issued a resolution modifying its bond auction system. The key change consisted of terminating the pre-announcement of the cut-off rate. Instead it was decided to introduce a system in which the rate on government and central bank paper would be determined on the basis of offers received up to the amount auctioned by the bank, which itself was to be based on the authorities' monetary program. Prior to each auction, the central bank provided information to market participants on the maximum and minimum rates offered and accepted in the previous auction. As a result of these measures, as well as the introduction of limits on noncompetitive bids (including limiting the participation of government entities in the competitive bidding process), and the improvement in macroeconomic performance, the bank was able to conduct a more effective monetary policy, as reflected by an increase in the outstanding stock of CAMs from L 208 million to L 510 million (about 20 percent of currency in circulation at the end of 1996). ${ }^{29}$ The improved fiscal situation and greater effectiveness in open market operations

${ }^{28}$ This excludes those held by public sector entities.

${ }^{29}$ The stock actually reached in excess of L 1.4 billion at end-September as the central bank made substantial efforts to sterilize the effects of inflows from higher coffee proceeds. Also, the bank was able to place in the market central government bonds in the amount of about I 700 million that were previously held by commercial banks to meet reserve requirements. 
was accompanied by a notable reduction in auction rates from 36 percent in January to 22 percent in December 1997.

37. On March 5, 1998, the bank issued a resolution aimed at allowing wider participation by a larger number of financial institutions in the auction of government and central bank paper and stimulating competition and efficiency in auction. As a result, as of end-June, six commercial banks had signed agreements to participate in the auctions, ${ }^{30}$ and as of end-June 1998, the stock of central bank certificates outstanding had increased by L 900 million (excluding those held by government entities), or about 11 percent of monetary base at the beginning of the year. ${ }^{31}$

\section{B. Reserve Requirements}

38. Since 1996, the CBH has tried to reduce the cost of financial intermediation by increasing the rate of remuneration on required reserves while reducing the nominal level of legal requirements. Prior to January 1997, reserve requirements (34 percentage points in the case of commercial banks; 21 points for development banks; and 15 percentage points for investment companies) were met by holding a combination of cash and deposits at the CBH (11 percentage points in the case of commercial banks), government bonds (bearing interest rates of 4 percent, 6 percent, and 12 percent, depending on the issue), special central bank certificates (equivalent to up to 7 percentage points of total deposits and remunerated at an interest rate equivalent to the average deposit rate), ${ }^{32}$ and government (including central bank) bonds sold at auctions (a maximum of 2 percentage points). ${ }^{33}$ These high reserve requirements-remunerated in most cases at below-market interest rates-contributed to disintermediation, as evidenced by the growth in the number of unregulated financial institutions and in off-balance-sheet transactions.

${ }^{30} \mathrm{Up}$ to that point, stock brokers in the two existing exchange houses had exclusive rights to participate in the auctions while receiving a 0.35 percent commission from the $\mathrm{CBH}$. With the new regulation, the $\mathrm{CBH}$ offered to pay the same commission to other financial agents willing to participate in the auctions.

${ }^{31}$ During the same period, the interest rate on government paper had declined from 21.9 percent to 19.4 percent.

${ }^{32}$ This rate was adjusted every month on the basis of changes in the average deposit rate; the rate at end-1996 was 21 percent per annum.

${ }^{33}$ This only highlights how cumbersome the reserve requirement system was before the January 1997 reform. Also, while only commercial banks had to meet their requirements by holding cash and deposits at the $\mathrm{CBH}$ (at least 11 percentage points), this requirement did not apply to development banks or investment companies. 
39. In early 1997 the $\mathrm{CBH}$ introduced a major overhaul of the reserve requirement system in an effort to simplify it and reduce existing distortions. Reserve requirements were unified at 12 percent (to be met only by cash-in-vault and deposits at the $\mathrm{CBH}$ ) for all financial institutions and across all types of financial obligations (including dollar deposits). Also, in order to limit the monetary effects of the nominal reduction in reserve requirements and reduce the implicit rate of taxation on intermediation, the $\mathrm{CBH}$ established that the difference between the existing rate and the new 12 percent level was to be made up by the obligatory purchase of CBH certificates remunerated at the average deposit rate.$^{34}$ Furthermore, in April and August 1997 the obligatory purchase requirement was reduced by 1 and 2 percentage points, respectively. In an effort to further reduce financial intermediation margins, while phasing out reserve requirements in the conduct of monetary policy, in April 1998 the CBH reduced obligatory deposits by 2 percentage points. ${ }^{35}$

40. Until late 1997, the effective implementation of monetary policy had been constrained by the widespread noncompliance with and avoidance of reserve requirements by financial institutions. Avoidance took the form of the banks' conversion of deposit liabilities into other types of financial liabilities (such as bankers' acceptances), which bankers interpreted as not being subject to reserve requirements. Avoidance also occurred through the transfer of banks' deposits to their nonbank subsidiaries which were subject to lower reserve requirements and less stringent supervision.

41. On March 13, 1997 the central bank issued a regulation clarifying the nature of instruments subject to reserve requirements. The regulation restated the objective of the legislation and earlier central bank resolutions which stressed that all liability instruments of the financial institutions, including deposits and all other instruments which are part of the process of financial intermediation, are subject to reserve requirements. Beginning on April 10, the Banking Commission (CNBS) began assessing reserve requirements on a monthly basis, calculating fines for noncompliance based on this definition.

\section{Other Policy Instruments}

- Effective late 1997, the central bank ceased granting credit for agriculture and other productive activities and housing through its specialized development funds

\footnotetext{
${ }^{34}$ Government paper (bearing below-market rates) that up to that point was used to meet reserve requirements was replaced by these $\mathrm{CBH}$ certificates; the $\mathrm{CBH}$ in turn sold the government bonds in auction after the government agreed to increase the coupon rate to that determined by the market.

${ }^{35}$ Reserve requirements on both domestic and foreign currency liabilities remained at the level established in early 1997-12 percent of deposit liabilities.
} 
FONDEPRO and FOVI ${ }^{36}$ All of the development bank activities carried out by the central bank were transferred to a second-tier bank (FONAPROVI) that was created in October 1997.

The central bank operates a lender of last resort facility for commercial banks facing liquidity problems. These credits have a maturity of up to a year, and bear a penalty rate of interest equivalent to the average maximum lending rate in the system plus 4 percentage points. These loans are collateralized by transferring custody to the central bank of physical assets or ownership shares of the bank in question.

Until April 1997, the central government was able to receive credit from the CBH by running overdrafts on the treasury account held at the central bank. For the first L 70 million in overdrafts, the government would pay a rate of 12 percent per annum and the latest auction rate for any amount exceeding $L 70$ million. The scheme was modified with the approval of the reforms to the central bank law that explicitly limit any direct credit to the government, except under emergency situations and seasonal shortfalls. $^{37}$

\section{Banking Supervision}

42. In October 1995, congress approved a law creating the National Commission for Banking and Insurance (CNBS). This commission would be responsible for issuing and enforcing all prudential regulations while absorbing all banking supervision tasks from the CBH. As such, the central bank law was modified to allow for the transfer of the superintendency of banks (SB) - up to that point a department in the CBH-to the newly created CNBS. In addition, the commission was given the jurisdictional powers to monitor compliance with reserve requirements.

43. The transfer of the SB to the CNBS was a tumultuous process. Approximately 50 percent of its personnel-mostly at a very specialized level - left the SB between May and June 1996, as they failed to get a compensation package comparable to the one they had at the CBH. As a result, the operative capacity of the new SB deteriorated and with it the level of prudential supervision in the banking system, with a parallel deterioration in the degree of monetary policy control.

44. The transition period meant a loss in monetary control given the SB's inability to enforce reserve requirements in the absence of trained personnel and the lack of credible

\footnotetext{
${ }^{36}$ The credit lines were made available to banks at an interest rate of 23 percent (unchanged since December 1994), and the banks were allowed in turn to charge 28 percent to the final borrower.
}

${ }^{37}$ The reforms to the law did not include setting a specific limit on indirect credit. 
sanctions. The SB's task was further complicated by the emergence of new financial instruments and institutions in the financial market, particularly as the existing legal framework was not clear about the treatment-as regards reserve requirements-to be given to these innovations.

45. In recent months, the commission, with support from the central bank and technical assistance from the Fund, has been making more determined efforts to improve bank supervision. Recent measures taken include:

- the placement of limits in June 1997 on short-term foreign debt by commercial banks equivalent to 50 percent of capital and reserves. This regulation was modified in April 1998 to limit total foreign indebtedness to no more than three times capital and reserves;

- the issue of regulations in June 1998 on risk-weighted minimum capital requirements following Basle Committee rules ( 8 percent of capital to be raised to 10 percent by mid-1999);

- the minimum capital requirement for commercial banks was raised in September 1997 from L 30 to $\mathrm{L} 50$ million (US\$4 million);

- publication of a new accounting manual-effective January 1998-intended to facilitate the auditing process (also helps in assessing compliance with reserve requirements);

- in October 1997 norms were issued on portfolio valuation procedures; and

- in March 1998 a specification of sanctions was issued, establishing penalties for noncompliance with prudential norms and regulations.

46. Other proposals being considered include (i) a framework for regulating connectedlending; (ii) regulations for open foreign currency position and maturity matching; (iii) establishment of a credit bureau; (iv) introduction of a CAMEL-based system for rating banks; (v) establishment of a deposit insurance scheme; and (vi) regulations over the activities of the stock exchange and pension funds. 


\section{Pension System ${ }^{38}$}

\section{A. Introduction}

47. This chapter reviews the basic features of the pension system in Honduras and main elements of proposals for reform. The pension system is based on a pay-as-you-go scheme and comprises a diversity of regimes managed by the state. The main concerns facing the pension system are that it is unviable in the medium term as current contributions are insufficient to cover future benefits; dispersed benefits and contributions have led to inequities among affiliates; and other distortions have weakened the role of the system as a provider of an adequate pension for retirement.

48. The pension reforms being considered by the government are designed to strengthen the financial position of the system, unify benefits and contributions, and improve management and supervision. The proposals envisage a basic pension to be provided by a public sector scheme, supplemented by a defined-contribution scheme based on individual contribution accounts, managed by the private sector. The government is seeking support from the labor and business sectors for the proposed reform and expects to submit the proposal to congress by end-1998.

\section{B. Features of the Present System}

49. The social security system in Honduras entails the pension system (old age, disability, and survivor) and a medical program (basic health and maternity benefits). The pension system comprises (i) the pension regime of the Honduran Institute of Social Security (IHSS) which constitutes the largest component of the system; ${ }^{39}$ (ii) two other regimes for basic education teachers (IMPREMA) and public sector workers (INJUPEMP); and (iii) special regimes for the army, state university, central bank, and journalists, which account for less than 1 percent of the labor force (Table 1). There are also a few small private pension funds based on individual contribution accounts that emerged in recent years to complement the pension benefits of the public sector regimes. The pension system is largely unsupervised and private pension funds are not guaranteed by the state. ${ }^{40}$

50. Coverage of the system is limited to main urban centers and fails to incorporate workers in the informal sector. Coverage has expanded slowly since the pension system started operating in 1972, with the number of contributors rising from 18 percent of the labor

\footnotetext{
${ }^{38}$ Prepared by Mario Garza.
}

${ }^{39} \mathrm{IHSS}$ is also the main provider of medical benefits in the social security and most members of the other pension regimes participate in this program.

${ }^{40} \mathrm{Legislation}$ is being considered to address this weakness. 
force in 1989 to 22 percent in 1997. The dependency ratio (i.e., the number of contributors to retirees) was $24: 1$ in 1997 , reflecting the short life span of the system.

51. Pension contributions are dispersed and rely on the share paid by the state. Contributions to the IHSS amount to 4 percent of an employee's salary ( 1 percent paid by the employee, 2 percent by the employer, and 1 percent by the government). For IMPREMA and INJUPEMP, contributions total 18 percent of an employee's salary ( 7 percent paid by the employee and 11 percent by the government). In the special regimes, contributions range from 15 to 35 percent of an employee's salary, with the treasury's share reaching up to 18 percent of an employee's salary (Table 2).

52. Pension benefits are also dispersed, mirroring the structure of contributions. The pension benefit from the IHSS consists of 40 percent of the basic salary (the average nominal contributory wage earned in the last 5 years) plus 1 percent of the basic salary for each year beyond 5 years of contribution. Pension benefits from IMPREMA and INJUPEMP consist of 3 percent and 2.75 percent of the basic salary (the average nominal wage earned in the last 3 years) for each year of service, respectively. Pension benefits are not adjusted by the change in consumer prices. Eligibility for benefits from the IHSS requires 15 years of contributions with a minimum retirement age of 65 years for men and 60 years for women. For IMPREMA and INJUPEMP, the requirement is 10 years of service with a minimum retirement age of 50 and 58 years, respectively.

\section{Issues and Problems}

53. On an actuarial basis, the weak financial position of the pension system stems mainly from excessive pension benefits relative to contributions. Under current life expectancy rates and eligibility rules, the (capitalized) value of contributions made to the IHSS for 20 years would only cover about half of future pension benefits paid to a male retiree ( 35 percent for a female due to a longer life expectancy). Despite higher contribution rates, this ratio would be about 55 percent for a retiree from IMPREMA and 85 percent from INJUPEMP. At the same time, the total reserves of the pension system (estimated at about 5 percent of GDP at end1997) have been poorly managed over the years, as they had been used to cover the deficit of the medical program, invested in low-yield housing projects, and diverted to subsidized lending programs. Overdue employers' contributions to the system stood at 0.5 percent of GDP at end-1997.

54. Notwithstanding these problems, the operations of the social security system recorded a small cash surplus during the period 1993-97 (Table 3). Reflecting the large number of contributors relative to retirees, contribution revenue (1.7 percent of GDP per year) exceeded pension and medical benefits ( 0.6 percent of GDP per year) over this period. At the same time, interest earnings on the system's reserves amounted to 0.8 percent of GDP a year while wages and other current expenditure averaged 0.6 percent of GDP a year. Social security 
savings (1.4 percent of GDP a year) were mostly used to cover capital outlays related to housing and lending programs to the system's affiliates.

55. The pension regime of the IHSS has been severely undermined by the use of a contributory salary ceiling, which has been fixed in nominal terms since the inception of the medical program in 1962. The contributory salary ceiling stands at $L 600$ per month for the two main cities where most contributors reside. To partly offset the adverse effect of inflation on contribution revenue, the IHSS broadened its affiliation base to include other urban centers and in-bond activities and set ceilings of $L 1,500$ and $L 2,000$ per month for these new affiliates. The low ceilings have effectively diluted pension benefits to a fraction of the minimum wage for many retirees and made contributions to the medical program insufficient to cover its operating costs.

56. The pension regimes of IMPREMA and INJUPEMP had engaged over the years on nonpension activities such as subsidized lending (mortgage and personal loans) and lowincome housing projects for selected affiliates. This practice has not only affected the financial position of these two regimes but also constituted a source of inequity among affiliates. An additional source of inequity in the system arises from a higher state contribution to the regimes of IMPREMA and INJUPEMP which has contributed to make pension benefits from these regimes more generous relative to those from the IHSS.

57. The pension system has also discouraged labor mobility because past contributions are partly recognized when affiliates shift from one pension regime to another due to changes of employment. In the case of the IHSS, only those contributions paid by the affiliate are returned (those paid by the employer and the state are appropriated by the IHSS) while, in the case of IMPREMA and INJUPEMP, all past contributions made on behalf of the affiliate are paid back, although the value of contributions is calculated using below-market interest rates.

58. In addition, the pension system has lacked a supervisory framework to oversee its operations and suffered from deficiencies in the management of the pension regimes, which has resulted in high administrative costs. More specifically, practices for internal control and assessment of budget execution have been weak, with delays in the issue of financial statements for the various regimes. Moreover, an adequate system for monitoring and control of subsidized loans is not in place, contributing to a high share of overdue loans, while a lack of expertise and poor management in the implementation of housing projects have resulted in sizable financial losses.

\section{Proposed Pension System}

59. The proposed pension reform aims at establishing a defined-contribution scheme, allowing private sector participation in the provision of pensions, setting up a supervisory framework, and eliminating inequities in the structure of benefits and contributions. The main elements of the proposed reform are as follows (see Tables 2 and 4): 
Structure: the proposed system would comprise (i) a public sector component managed by existing pension institutions (i.e., IHSS, IMPREMA, and INJUPEMP) to provide for a basic pension (basic pillar); and (ii) a private sector component to provide a complementary pension (complementary pillar). Private pension funds would be allowed to operate the complementary pillar and individual contribution accounts would be developed for both pillars.

- Benefits and contributions: pension benefits from both pillars would be strictly based on capital accumulated through worker contributions and returns on those contributions. The pension contribution would be 3 percent of an employee's salary for the basic pillar, 8 percent for the complementary pillar, and 3 percent for disability and survivor insurance. The contributory salary would be subject to a ceiling of 10 times the minimum wage. The retirement age would be set up at 65 years of age for men and 60 years for women.

- Coverage: current affiliates to the IHSS pension regime, affiliates to other pension regimes under the age of 30 years, and new affiliates would join the new system. Other affiliates may voluntarily shift to the proposed system. Past contributions made to the present system would be shifted to the individual accounts in the proposed system.

Regulatory framework: a supervisory authority would be established to oversee the operations of the existing and new pension systems. Prudential provisions would also be set up for capital requirements, investment rules, and entry/exit guidelines for private pension funds. Public pension funds would be subject to performance criteria for management and profitability of reserves, and control over administrative costs. The supervisory authority would also regulate commissions, enforce contribution collection, and assess quality of portfolio. An investment grading commission would periodically review investment guidelines and risk, while insurance companies would be allowed to offer life pension annuities to retirees in exchange of accumulated capital.

- Overhaul of the present regimes: the pension regime and medical program of the IHSS would be split into separate operations while the contributory ceiling would be raised to 10 times the minimum wage. The envisaged increase in contribution revenue would allow coverage of health services to expand while eliminating the deficit of the medical program. Subsidized lending and housing programs would be discontinued while the state pension contribution would also be eliminated.

Transitional regime: to encourage the shift to the proposed system, pension contributions for workers that decide to remain affiliated to the IMPREMA, INJUPEMP, and the special regimes would be kept at about 18-19 percent of the workers' salary (compared with combined contributions of 14 percent under the new 
system) while the retirement age in these regimes would be raised by one year per annum to the same age as in the proposed system.

60. The proposed pension system would improve the sustainability prospects of the pension system and encourage workers' affiliation, as contributions would be linked to future pension benefits. Nevertheless, the authorities would need to assess the potential fiscal cost of the reform (such as a loss of contributions from the shift of workers to the new system) and the policy response to absorb the transitional costs of the reform. To avoid delays in implementing the reform, the authorities should introduce first those measures that require no congressional approval such as the envisaged steps to overhaul the current pension regimes, together with stepwise increases in the contributory rate to the IHSS, and in the retirement ages for the other pension regimes. 
Table 1. Honduras: Main Features of the Present Pension System

\begin{tabular}{|c|c|c|c|}
\hline \multirow[b]{2}{*}{ Features } & \multicolumn{3}{|c|}{ Pay-as-you-go Scheme } \\
\hline & IHSS & MMPREMA & INJPEMP \\
\hline Participants & $\begin{array}{l}\text { Workers in the private sector and local } \\
\text { governments }\end{array}$ & $\begin{array}{l}\text { Teachers of primary and secondary } \\
\text { education in the private and public sectors }\end{array}$ & $\begin{array}{l}\text { Workers in the central government, } \\
\text { legislative and judicial powers, public } \\
\text { enterprises, and most decentralized agencies }\end{array}$ \\
\hline $\begin{array}{l}\text { Contributory salary } \\
\text { ceiling }\end{array}$ & $\begin{array}{l}\text { Contributory salary is subject to ceilings of } \\
L 600, L 1,500 \text {, and } L 2,000 \text { per month } \\
\text { depending on place of residency }\end{array}$ & Actual salary & Actual salary \\
\hline Basic wage & $\begin{array}{l}\text { Average nominal contributory salary during } \\
\text { last } 5 \text { working years. }\end{array}$ & Average wage during last 3 working years & Average wage during last 3 working years \\
\hline Retirement age & $\begin{array}{l}65 \text { years for men and } 60 \text { years for women; } \\
\text { and } 15 \text { years of contribution }\end{array}$ & 50 years and 10 years of service & 58 years and 10 years of service \\
\hline Benefits & $\begin{array}{l}40 \text { percent of basic wage and one percent of } \\
\text { basic wage for each year beyond } 5 \text { years of } \\
\text { contribution }\end{array}$ & $\begin{array}{l}3 \text { percent of basic wage for each year of } \\
\text { service }\end{array}$ & $\begin{array}{l}2.75 \text { percent of basic wage for each year of } \\
\text { service }\end{array}$ \\
\hline
\end{tabular}

Sources: Ministry of Finance, National Institute of Social Security; and teachers and civil service pension funds. 
Table 2. Honduras: Contributions to the Social Security System

(In percent of employee's salary)

Employer Employee State Total

I. Defined-benefit scheme (current system)

\begin{tabular}{|c|c|c|c|c|}
\hline \multicolumn{5}{|l|}{ Pension regimes: } \\
\hline IHSS $1 /$ & 1.0 & 2.0 & 1.0 & 4.0 \\
\hline \multicolumn{5}{|l|}{ IMPREMA } \\
\hline Public sector & 7.0 & 0.0 & 12.0 & 19.0 \\
\hline Private sector & 7.0 & 0.0 & 11.0 & 18.0 \\
\hline INJUPEMP & 7.0 & 0.0 & 11.0 & 18.0 \\
\hline Special regimes $2 /$ & $3.0-9.0$ & $0-32.0$ & $0-18.0$ & $15.0-35.0$ \\
\hline \multicolumn{5}{|l|}{ Medical program: } \\
\hline IHSS $1 /$ & 2.5 & 5.0 & 2.5 & 10.0 \\
\hline \multicolumn{5}{|c|}{ II. Defined-contribution scheme (proposed system) } \\
\hline Pension contribution & 3.0 & 11.0 & 0.0 & 14.0 \\
\hline Basic pillar & 3.0 & 0.0 & 0.0 & 3.0 \\
\hline Complementary pillar & 0.0 & 8.0 & 0.0 & 8.0 \\
\hline Disability and survivor & 0.0 & 3.0 & 0.0 & 3.0 \\
\hline Transitional regime 3/ & 11.0 & 8.0 & 0.0 & 19.0 \\
\hline
\end{tabular}

Sources: Ministry of Finance; and National Institute of Social Security.

1/ Contributory wage subject to a ceiling of $L 600$ per month in Tegucigalpa and San Pedro Sula and of $L 1,500$ and $L 2,000$ per month in other cities.

$2 /$ For the army, state university, the central bank, and journalists.

3/ For workers that remain affiliated to the current pension regimes from IMPREMA, INJUPEMP, and special regimes. 
Table 3. Honduras: Consolidated Operations of the Social Security Agencies $1 /$

(In percent of GDP)

\begin{tabular}{|c|c|c|c|c|c|}
\hline & 1993 & 1994 & 1995 & 1996 & $\begin{array}{l}\text { Prel. } \\
1997 \\
\end{array}$ \\
\hline Total revenue & 2.6 & 2.6 & 2.8 & 2.6 & 2.8 \\
\hline Current revenue & 2.5 & 2.4 & 2.7 & 2.5 & 2.7 \\
\hline Contributions & 1.9 & 1.8 & 1.7 & 1.4 & 1.6 \\
\hline Interest earnings & 0.9 & 0.8 & 0.8 & 0.8 & 0.8 \\
\hline Other $2 /$ & -0.2 & -0.1 & 0.2 & 0.3 & 0.3 \\
\hline Capital revenue & 0.1 & 0.2 & 0.1 & 0.1 & 0.2 \\
\hline Total expenditure & 2.7 & 2.8 & 2.6 & 2.4 & 2.2 \\
\hline Current expenditure & 1.3 & 1.3 & 1.2 & 1.1 & 1.0 \\
\hline Wages and salaries & 0.4 & 0.4 & 0.3 & 0.3 & 0.3 \\
\hline Current transfers & 0.6 & 0.6 & 0.6 & 0.5 & 0.6 \\
\hline Other & 0.3 & 0.4 & 0.3 & 0.2 & 0.2 \\
\hline Capital expenditure and net lending & 1.4 & 1.4 & 1.4 & 1.3 & 1.1 \\
\hline Fixed capital formation & 1.0 & 1.1 & 1.1 & 0.7 & 0.4 \\
\hline Net lending & 0.4 & 0.3 & 0.2 & 0.6 & 0.8 \\
\hline Primary balance & -0.9 & -0.9 & -0.6 & -0.6 & -0.1 \\
\hline Current account balance & 1.3 & 1.1 & 1.5 & 1.5 & 1.7 \\
\hline Overall balance & -0.1 & -0.2 & 0.2 & 0.2 & 0.7 \\
\hline
\end{tabular}

Sources: Central Bank of Honduras; Honduran Institute Social Security; and Fund staff estimates.

1/ Comprises the National Institute of Social Security (IHSS); and the teachers and civil service pension funds. $2 /$ Includes changes in accounts receivable. 
Table 4. Honduras: Main Features of the Proposed Pension System

\begin{tabular}{|c|c|c|c|}
\hline Features & Basic pillar & Complementary pillar & Transitional regime \\
\hline Participants & $\begin{array}{l}\text { New workers, affiliates to IHSS, and } \\
\text { affiliates to other pension regimes under } \\
30 \text { years of age }\end{array}$ & Same as basic pillar & $\begin{array}{l}\text { Affiliates to other pension regimes over } 30 \text { years of } \\
\text { age that did not shift to the new system }\end{array}$ \\
\hline $\begin{array}{l}\text { Contributory salary } \\
\text { cejling }\end{array}$ & 10 times the minimum wage & Same as basic pillar & Actual salary \\
\hline Benefits & $\begin{array}{l}\text { Based on capital accumulated through } \\
\text { workers' contributions and retums to } \\
\text { those contributions }\end{array}$ & Same as basic pillar & $\begin{array}{l}\text { For unshifted affiliates, same as in present system. } \\
\text { For shifted affiliates, benefits are an average of } \\
\text { benefits under the present system and benefits } \\
\text { under the new system, weighted by the years of } \\
\text { contribution to each system. }\end{array}$ \\
\hline
\end{tabular}

Sources: Ministry of Finance and the Presidential Commission for State Modernization. 


\section{EXCHANGE SYSTEM ${ }^{41}$}

\section{A. Antecedents to the Present Exchange System}

61. After the collapse of the exchange peg in 1990 that was triggered by the expansionary policies of the 1980s, the central bank initiated efforts to reform the exchange system. Under these initial reforms, a number of distortions and exchange restrictions that had been used to defend the exchange peg were eliminated. Also, all restrictions on the holdings of foreign exchange deposits in the commercial banks and on their use were removed, and most foreign exchange transactions were shifted to the commercial banks, and conducted at freely negotiated rates within a band of 2.5 percent around the official rate. In turn, the central bank set the official exchange rate on the basis of conditions prevailing in the interbank and parallel markets.

62. The exchange system was liberalized further in 1992 as the lempira was allowed to float freely in the interbank market. The central bank intervened in the foreign exchange market only to ensure that its target for net international reserves was met, but banks and exchange houses were obliged to surrender 20 percent of their foreign exchange purchases. Under the reform, the lempira depreciated substantially ( 50 percent in real effective terms during the period 1990-92), and helped restore external competitiveness in the face of a decline in the terms of trade ( 30 percent during the same period). Also, the exchange rate spread between the parallel and official markets declined to less than 2 percent from the much higher differentials (at times, as high as 70 percent) observed prior to 1990.

63. Financial policies were relaxed in the wake of a general election in November 1993, and the exchange rate depreciated further, i.e., by 17 percent in real terms in the 18 -month period ended in mid-1994. Imperfections in the functioning of the interbank market amplified the volatility in the exchange rate in this period, and in June 1994 the authorities decided to suspend temporarily the exchange rate float. It was expected that an auction mechanism would be introduced as a temporary measure while weaknesses in the interbank market were addressed. Steps were identified in 1994, with the technical assistance from the Fund, to improve the infrastructure, increase supervision, and enhance transparency in the interbank market. However, progress in implementing these steps was slow and the auction has been converted into a virtually permanent arrangement.

\section{B. The Interbank Market}

64. For many years, the development of the interbank market had been inhibited by a high degree of concentration in the banking system and the active role of the central bank as a provider of short-term liquidity. These conditions changed little with the advent of floating in the context of the interbank market, with the result that the market lacked sufficiently broad

\footnotetext{
${ }^{41}$ Prepared by Mario Garza.
} 
participation by financial institutions which led to some concerns about collusion among the main, large participants. The key problems that had impaired the functioning of the interbank market centered on the following areas:

- Inadequate trading infrastructure: Lack of trading desks and an underdeveloped clearing system for foreign exchange operations resulted in low trading activity among intermediaries (banks and exchange houses) and poor dissemination of data within the market. Appropriate information standards were not put in place, making it difficult to obtain a representative exchange rate used in daily operations with the public.

- High concentration of operations in a few banks: Six banks accounted for an estimated half of foreign exchange purchased from the public. This situation limited access to the exchange market because those banks were inclined to sell foreign exchange to their associated industrial and/or trading groups. Smaller agents usually looked to the parallel market to satisfy their foreign exchange needs.

- Insufficient supervision and restrictive regulations: Lack of prudential standards, including a conduct code for operators, made supervision of intermediaries weak. The central bank maintained restrictive foreign exchange regulations that resulted in high surrender requirements (up to 50 percent of purchases); purchases of exchange surrenders at below-market exchange rates; and a structure of operating fees, which did not permit intermediaries to determine their own spread.

- Weak instruments of monetary policy: The central bank continued to be an important source of short-term liquidity, preventing the development of an interbank market and secondary trading of open market instruments. Also, weak enforcement of existing reserve requirements, and the absence of limits on open foreign exchange positions allowed banks to satisfy their liquidity requirements without recourse to other financial intermediaries.

\section{Features of the Present Exchange System}

65. The exchange system is based on a daily foreign exchange auction conducted by the central bank. The supply of foreign exchange to the auction is based on the requirement for full surrender of all current proceeds, except for exports to Central America and private remittances. Currently, the central bank offers for sale in the auction a minimum of 60 percent of its purchases of foreign exchange from banks and other authorized institutions. This minimum amount, as well as the base price obtained in the previous day's auction are announced before each new auction. Prospective buyers in the auction have to make offers to purchase amounts ranging from US $\$ 5,000$ to US $\$ 300,000$, and the auction rate is determined as the 
average of accepted bids on the basis of a Dutch auction, and may not exceed the base rate ${ }^{42}$ by $+/-7$ percent. Regarding the buying and selling rate spread, current rules mandate that intermediaries sell foreign exchange with a markup of up to 1.5 percent over the auction rate and that the central bank buys foreign exchange at the auction rate of the previous day plus a commission of 0.6 percent.

\section{Recent Exchange Rate Developments}

66. Over most of the period from June 1994 to December 1996, the exchange rate was at the most depreciated limit of the bidding band and, in view of the authorities' policy of maintaining unchanged the nominal exchange rate, rationing of foreign exchange had to be used as the basis for meeting demands and the real exchange rate appreciated sharply. Despite this, the spread between the parallel and auction exchange rates remained small. The net international reserves position of the central bank improved significantly during this period while short-term private capital inflows emerged, reflecting a sharp increase in domestic interest rates. The interest rate differential between central bank instruments and those available in the United States rose from about 10 percent at end-1994 to close to 30 percent at end-1996 (Figure 5).

67. The central bank continued to pursue a policy of maintaining largely fixed the nominal exchange rate during 1997 in an attempt to hold down inflationary pressures. This policy, combined with a marked inflow of short-term private capital inflows that stemmed from high interest rates and the government's exchange rate policy, led to a marked increase in net international reserves and sales of foreign exchange in the auction (Tables 1 and 2), ${ }^{43}$ and the real exchange rate appreciated by almost 17 percent. The rate of appreciation slowed slightly in the first half of 1998 in line with a small decline in coffee prices and a downturn in capital inflows.

\footnotetext{
${ }^{42}$ The base rate is adjusted every 5 auctions in line with the (estimated) differential in inflation rates between Honduras and its main trading partners.
}

${ }^{43}$ Sales of foreign exchange in the auction increased markedly in the third and fourth quarters of 1997, and gross international reserves declined markedly. 
Figure 5. Honduras: Exchange and Interest Rate Developments

Monthly Exchange Rates

(Lempiras per U.S. dollar)

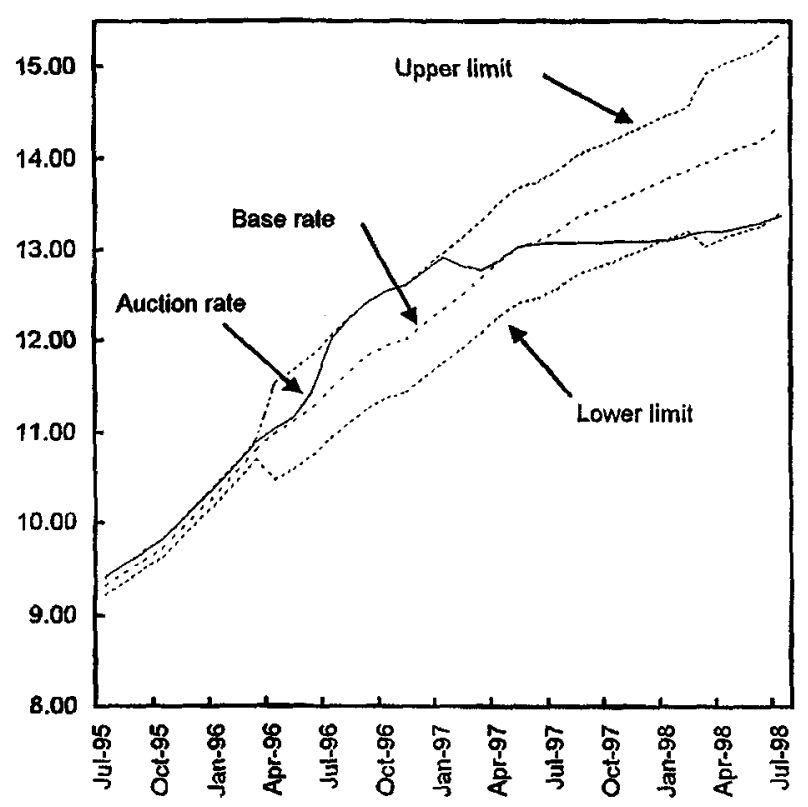

Interest Rate Differential 1/

(In percent)

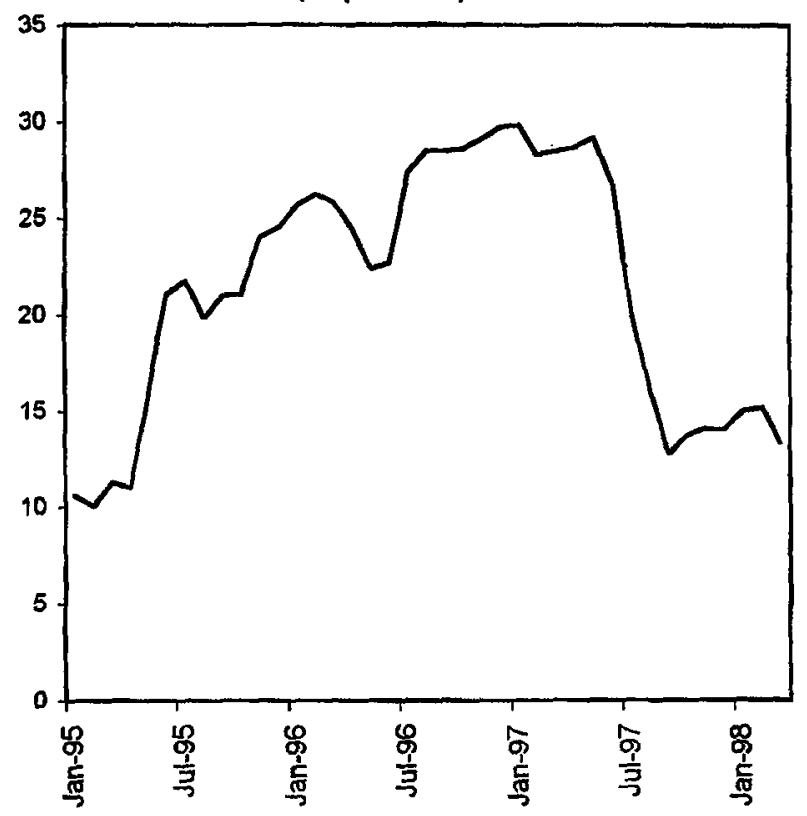

Real Effective Exchange Rate

$(1990=100)$

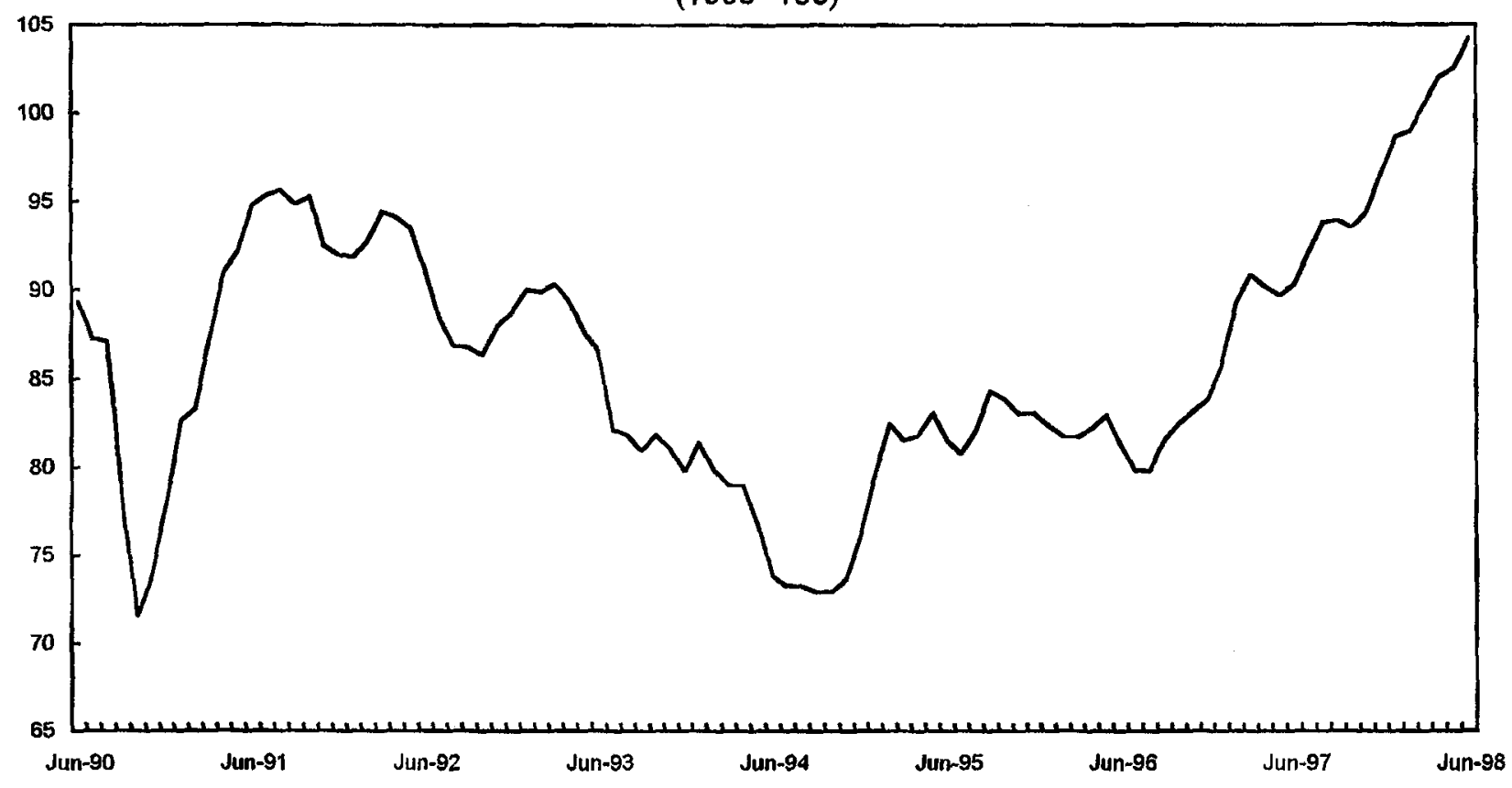

Sources: Central Bank of Honduras; and Fund staff estimates.

1/ Spread between interest rate on 90 -day central bank bonds (adjusted by the depreciation of the lempira against the U.S. dollar) and LIBOR. 
Table 1. Honduras: Foreign Exchange Operations in the Auction (Monthly average in millions of U.S. dollars)

\begin{tabular}{|c|c|c|c|}
\hline Period & $\begin{array}{c}\text { Purchases by } \\
\text { the Central Bank }\end{array}$ & $\begin{array}{l}\text { Amount } \\
\text { Supplied 1/ } \\
\end{array}$ & Amount Sold \\
\hline \multicolumn{4}{|l|}{1994} \\
\hline III & 85.4 & 60.0 & 59.9 \\
\hline IV & 120.9 & 65.6 & 64.4 \\
\hline \multicolumn{4}{|l|}{1995} \\
\hline $\mathbf{I}$ & 137.5 & 104.8 & 95.1 \\
\hline II & 104.9 & 73.1 & 73.1 \\
\hline III & 70.3 & 49.3 & 49.2 \\
\hline IV & 94.6 & 46.2 & 44.7 \\
\hline \multicolumn{4}{|l|}{1996} \\
\hline I & 99.7 & 68.6 & 68.6 \\
\hline II & 103.5 & 62.5 & 66.0 \\
\hline III & 90.3 & 56.2 & 61.2 \\
\hline IV & 108.4 & 53.7 & 58.5 \\
\hline \multicolumn{4}{|l|}{1997} \\
\hline$I$ & 148.7 & 52.0 & 87.7 \\
\hline II & 134.6 & 57.2 & 75.7 \\
\hline III & 131.1 & 62.0 & 98.8 \\
\hline IV & 168.5 & 66.0 & 120.9 \\
\hline \multicolumn{4}{|l|}{1998} \\
\hline I & 219.3 & 75.0 & 147.6 \\
\hline II & 194.0 & 65.2 & 126.7 \\
\hline
\end{tabular}

Source: Central Bank of Honduras.

1/ In June 1996 the amount offered became the minimum amount to be sold in the auction. 
Table 2. Honduras: Net International Reserve Coverage

\begin{tabular}{|c|c|c|c|c|c|c|c|c|}
\hline & \multicolumn{2}{|c|}{ Dec. } & \multicolumn{4}{|c|}{1997} & \multicolumn{2}{|c|}{1998} \\
\hline & 1995 & 1996 & March & June & Sept. & Dec. & March & June \\
\hline \multicolumn{9}{|c|}{ (In millions of U.S. dollars; end of period stocks) } \\
\hline Net international reserves & 113.2 & 211.0 & 314.1 & $\mathbf{4 2 5 . 6}$ & 445.6 & 491.5 & 606.0 & 639.8 \\
\hline Short-term liabilities & 282.2 & $\mathbf{3 4 3 . 7}$ & 514.1 & 578.1 & 576.0 & 614.8 & 753.0 & 692.2 \\
\hline Currency issue & 200.9 & 201.6 & 209.0 & 201.4 & 180.3 & 250.1 & 262.2 & 234.5 \\
\hline Reserve requirements & 72.3 & 120.0 & 217.4 & 257.3 & 253.1 & 307.2 & 332.0 & 308.0 \\
\hline Bonds & 9.0 & 22.1 & 87.7 & 119.4 & 142.6 & 57.5 & 158.9 & 149.7 \\
\hline \multicolumn{9}{|c|}{ (In percent of net international reserves) } \\
\hline Short-term liabilities & 249.4 & 162.9 & 163.7 & 135.8 & 129.3 & 125.1 & 124.3 & 108.2 \\
\hline Currency issue & 177.5 & 95.6 & 66.5 & 47.3 & 40.5 & 50.9 & 43.3 & 36.7 \\
\hline Reserve requirements & 63.9 & 56.9 & 69.2 & 60.5 & 56.8 & 62.5 & 54.8 & 48.1 \\
\hline Bonds & 7.9 & 10.5 & 27.9 & 28.1 & 32.0 & 11.7 & 26.2 & 23.4 \\
\hline \multicolumn{9}{|c|}{ (In percent of liabilities) } \\
\hline Short-term liabilities & 40.1 & 61.4 & 61.1 & 73.6 & 77.4 & 79.9 & 80.5 & 92.4 \\
\hline Currency issue & 56.3 & 104.6 & 150.3 & 211.3 & 247.2 & 196.5 & 231.1 & 272.8 \\
\hline Reserve requirements & 156.5 & 175.8 & 144.5 & 165.4 & 176.1 & 160.0 & 182.6 & 207.7 \\
\hline Bonds & $1,258.5$ & 956.2 & 358.1 & 356.4 & 312.4 & 855.1 & 381.5 & 427.3 \\
\hline \multicolumn{9}{|l|}{ Memorandum items: } \\
\hline \multicolumn{9}{|l|}{$\begin{array}{l}\text { Net foreign assets of the } \\
\text { banking system (In millions }\end{array}$} \\
\hline of U.S. dollars) & 19.4 & 63.0 & 38.0 & 73.8 & 55.3 & 8.4 & 1.2 & $\ldots$ \\
\hline Exchange rate (L per US $\$$ ) & 10.34 & 12.87 & 12.74 & 13.07 & 13.09 & 13.09 & 13.16 & 13.32 \\
\hline
\end{tabular}

Source: Central Bank of Honduras. 
Table 1. Honduras: National Accounts

(In millions of current lempiras)

\begin{tabular}{|c|c|c|c|c|c|}
\hline & 1993 & 1994 & 1995 & 1996 & $\begin{array}{l}\text { Prel. } \\
1997 \\
\end{array}$ \\
\hline Consumption & 17,442 & 21,646 & 28,606 & 37,762 & 48,515 \\
\hline General government & 2,405 & 2,780 & 3,535 & 4,556 & 5,377 \\
\hline Private sector & 15,037 & 18,866 & 25,071 & 33,206 & 43,138 \\
\hline Gross domestic investment & 7,614 & 10,861 & 11,836 & 14,510 & 18,318 \\
\hline Fixed capital formation & 6,535 & 8,110 & 8,994 & 11,110 & 14,425 \\
\hline Public sector & 2,839 & 3,001 & 3,504 & 3,929 & 4,095 \\
\hline Private sector & 3,696 & 5,109 & 5,490 & 7,181 & 10,330 \\
\hline Inventory changes & 1,079 & 2,751 & 2,842 & 3,400 & 3,893 \\
\hline Gross domestic expenditure & 25,056 & $\mathbf{3 2 , 5 0 7}$ & 40,442 & 52,272 & 66,833 \\
\hline $\begin{array}{l}\text { Exports of goods and } \\
\text { nonfactor services }\end{array}$ & 7,107 & 10,201 & 14,158 & 19,386 & 23,342 \\
\hline Imports of goods and & & & & & \\
\hline nonfactor services & $-9,474$ & $-13,846$ & $-17,094$ & $-23,884$ & $-29,090$ \\
\hline GDP at market prices & 22,689 & 28,862 & $\mathbf{3 7 , 5 0 7}$ & 47,774 & 61,084 \\
\hline Net factor payments & -906 & -740 & -967 & -659 & 975 \\
\hline Factor receipts from abroad & 673 & 1,232 & 1,799 & 2,755 & 4,467 \\
\hline Factor payments abroad & $-1,579$ & $-1,972$ & $-2,767$ & $-3,415$ & $-3,492$ \\
\hline GNP at market prices & 21,783 & 28,123 & 36,539 & 47,114 & 62,059 \\
\hline Indirect taxes & 3,314 & 4,230 & 4,976 & 6,733 & 8,332 \\
\hline Subsidies & 120 & 138 & 95 & 130 & 120 \\
\hline GDP at factor cost & 19,495 & 24,770 & 32,626 & 41,171 & 52,872 \\
\hline GNP at factor cost & 18,589 & 24,031 & 31,658 & 40,511 & 53,847 \\
\hline Depreciation & $-1,372$ & $-1,707$ & $-2,258$ & $-2,798$ & $-3,390$ \\
\hline National income & 17,217 & 22,324 & 29,400 & $\mathbf{3 7 , 7 1 3}$ & $\mathbf{5 0 , 4 5 7}$ \\
\hline
\end{tabular}

Sources: Central Bank of Honduras; and Fund staff estimates. 
Table 2. Honduras: National Accounts at Constant Prices

(In millions of 1978 lempiras)

\begin{tabular}{|c|c|c|c|c|c|}
\hline & 1993 & 1994 & 1995 & 1996 & $\begin{array}{l}\text { Prel. } \\
1997 \\
\end{array}$ \\
\hline Consumption & 4,495 & 4,506 & 4,843 & 4,940 & 5,148 \\
\hline General government & 532 & 505 & 496 & 516 & 548 \\
\hline Private sector & 3,963 & 4,001 & 4,347 & 4,424 & 4,600 \\
\hline Gross domestic investment & 1,693 & 1,817 & 1,621 & 1,700 & 1,782 \\
\hline Fixed capital formation & 1,516 & 1,514 & 1,312 & 1,387 & 1,502 \\
\hline Public sector & 665 & 548 & 490 & 457 & 385 \\
\hline Private sector & 851 & 966 & 822 & 930 & 1,117 \\
\hline Inventory changes & 177 & 303 & 309 & 313 & 280 \\
\hline Gross domestic expenditure & 6,188 & 6,323 & 6,463 & 6,640 & 6,930 \\
\hline $\begin{array}{l}\text { Exports of goods and } \\
\text { nonfactor services }\end{array}$ & 1,547 & 1,366 & 1,511 & 1,633 & 1,570 \\
\hline $\begin{array}{l}\text { Tmports of goods and } \\
\text { nonfactor services }\end{array}$ & $-1,750$ & $-1,782$ & $-1,826$ & $-1,899$ & $-1,842$ \\
\hline GDP at market prices & 5,985 & 5,907 & 6,148 & 6,374 & 6,658 \\
\hline Net factor payments & -143 & -89 & -102 & -39 & 75 \\
\hline Factor receipts from abroad & 149 & 165 & 194 & 234 & 295 \\
\hline Factor payments abroad & -292 & -254 & -296 & -273 & -220 \\
\hline GNP at market prices & 5,842 & 5,818 & 6,047 & 6,335 & 6,733 \\
\hline Indirect taxes & -612 & -634 & -576 & -629 & -648 \\
\hline Subsidies & 23 & 21 & 11 & 12 & 9 \\
\hline GDP at factor cost & 5,396 & 5,294 & $\mathbf{5 , 5 8 3}$ & $\mathbf{5 , 7 5 7}$ & 6,019 \\
\hline GNP at factor cost & 5,253 & 5,205 & 5,482 & 5,718 & 6,094 \\
\hline Depreciation & -335 & -343 & -353 & -360 & -368 \\
\hline National income & 4,918 & 4,862 & 5,129 & 5,358 & 5,726 \\
\hline Terms of trade effect & -259 & -60 & 2 & -107 & -113 \\
\hline $\begin{array}{l}\text { National income adjusted by } \\
\text { terms of trade }\end{array}$ & 4,659 & 4,802 & 5,131 & 5,251 & 5,613 \\
\hline
\end{tabular}

Sources: Central Bank of Honduras; and Fund staff estimates. 
Table 3. Honduras: Origin of Gross Domestic Product

\begin{tabular}{|c|c|c|c|c|c|}
\hline & 1993 & 1994 & 1995 & 1996 & $\begin{array}{l}\text { Prel. } \\
1997 \\
\end{array}$ \\
\hline \multicolumn{6}{|c|}{ (In millions of current lempiras) } \\
\hline Gross domestic product at factor cost & 19,495 & 24,770 & 32,779 & 41,648 & $\mathbf{5 3 , 3 3 0}$ \\
\hline Primary production & 4,383 & 6,484 & 7,655 & 9,946 & 12,868 \\
\hline Agriculture and related sectors & 4,014 & 6,030 & 7,026 & 9,188 & 11,971 \\
\hline Mining & 369 & 454 & 629 & 763 & 920 \\
\hline Secondary production & 5,502 & 6,679 & 9,540 & 12,231 & 15,504 \\
\hline Manufacturing & 3,456 & 4,275 & 5,818 & 7,455 & 9,535 \\
\hline Construction & 1,457 & 1,465 & 1,791 & 1,900 & 2,268 \\
\hline Utilities & 589 & 939 & 1,778 & 2,540 & 3,263 \\
\hline Services & 9,610 & 11,607 & 15,584 & 19,471 & 24,958 \\
\hline Transport and communications & 1,116 & 1,309 & 1,546 & 1,824 & 2,557 \\
\hline Commercial services & 2,056 & 2,555 & 3,915 & 4,903 & 6,264 \\
\hline Financial services & 1,654 & 2,205 & 3,007 & 3,678 & 5,061 \\
\hline Housing services & 1,162 & 1,441 & 1,832 & 2,317 & 2,941 \\
\hline Public administration & 1,509 & 1,547 & 1,912 & 2,429 & 2,896 \\
\hline Other services & 2,113 & 2,550 & 3,372 & 4,174 & 5,196 \\
\hline \multicolumn{6}{|c|}{ (In millions of 1978 lempiras) } \\
\hline Gross domestic product at factor cost & 5,396 & 5,290 & 5,603 & 5,796 & 6,045 \\
\hline Primary production & 1,490 & 1,499 & 1,636 & 1,681 & 1,737 \\
\hline Agriculture and related sectors & 1,404 & 1,416 & 1,540 & 1,578 & 1,629 \\
\hline Mining & 86 & 83 & 96 & 103 & 108 \\
\hline Secondary production & 1,297 & 1,210 & 1,275 & 1,325 & 1,371 \\
\hline Manufacturing & 813 & 798 & 842 & $881^{\circ}$ & 935 \\
\hline Construction & 344 & 282 & 264 & 234 & 240 \\
\hline Utilities & 140 & 130 & 149 & 172 & 185 \\
\hline Services & 2,609 & 2,581 & 2,692 & 2,790 & 2,938 \\
\hline Transport and communications & 456 & 443 & 477 & 498 & 532 \\
\hline Commercial services & 572 & 572 & 604 & 631 & 653 \\
\hline Financial services & 449 & 479 & 524 & 555 & 606 \\
\hline Housing services & 347 & 361 & 369 & 384 & 399 \\
\hline Public administration & 334 & 281 & 269 & 275 & 273 \\
\hline Other services & 451 & 449 & 449 & 446 & 459 \\
\hline
\end{tabular}

Source: Central Bank of Honduras. 
Table 4. Honduras: Financing of Investment

\begin{tabular}{|c|c|c|c|c|c|}
\hline & 1993 & 1994 & 1995 & 1996 & $\begin{array}{r}\text { Prel. } \\
1997 \\
\end{array}$ \\
\hline \multicolumn{6}{|c|}{ (In millions of lempiras) } \\
\hline Gross domestic investment & 7,614 & 10,861 & 11,836 & 14,510 & 18,318 \\
\hline Fixed capital formation & 6,535 & 8,110 & 8,994 & 11,110 & 14,425 \\
\hline Public sector & 2,839 & 3,001 & 3,504 & 3,929 & 4,095 \\
\hline Private sector & 3,696 & 5,109 & 5,490 & 7,181 & 10,330 \\
\hline Change in inventories & 1,079 & 2,751 & 2,842 & 3,400 & 3,893 \\
\hline Financing of investment & 7,614 & 10,861 & 11,836 & 14,510 & 18,318 \\
\hline Gross national savings & 5,770 & 8,305 & 10,413 & 12,649 & 17,600 \\
\hline Public sector $1 /$ & 448 & 1,010 & 2,666 & 2586 & 3481 \\
\hline Private sector & 5,322 & 7,295 & 7,747 & 10,063 & 14,119 \\
\hline External savings & 1,844 & 2,556 & 1,423 & 1,861 & 718 \\
\hline \multicolumn{6}{|c|}{ (In percent of GDP) } \\
\hline Gross domestic investment & 33.6 & 37.6 & 31.6 & 30.4 & 30.0 \\
\hline Fixed capital formation & 28.8 & 28.1 & 24.0 & 23.3 & 23.6 \\
\hline Public sector & 12.5 & 10.4 & 9.3 & 8.2 & 6.7 \\
\hline Private sector & 16.3 & 17.7 & 14.6 & 15.0 & 16.9 \\
\hline Change in inventories & 4.8 & 9.5 & 7.6 & 7.1 & 6.4 \\
\hline Financing of investment & 33.6 & 37.6 & 31.6 & 30.4 & 30.0 \\
\hline Gross national savings & 25.4 & 28.8 & 27.8 & 26.5 & 28.8 \\
\hline Public sector $1 /$ & 2.0 & 3.5 & 7.1 & 5.4 & 5.7 \\
\hline Private sector & 23.5 & 25.3 & 20.7 & 21.1 & 23.1 \\
\hline External savings & 8.1 & 8.9 & 3.8 & 3.9 & 1.2 \\
\hline \multicolumn{6}{|l|}{ Gross national savings as percent } \\
\hline of national disposable income & 25.1 & 27.8 & 26.7 & 25.1 . & 26.6 \\
\hline \multicolumn{6}{|l|}{ Memorandum items: } \\
\hline Nominal GDP (in millions of lempiras) & 22,689 & 28,862 & 37,507 & 47,774 & 61,084 \\
\hline \multicolumn{6}{|l|}{ A verage exchange rate } \\
\hline (lempira/U.S. dollar) & 6.5 & 8.4 & 9.5 & 11.7 & 13.0 \\
\hline National disposable income $2 /$ & 22,988 & 29,917 & 39,026 & 50,391 & 66,113 \\
\hline
\end{tabular}

Sources: Central Bank of Honduras; and Fund staff estimates.

1/Equivalent to the current account balance of the nonfinancial public sector.

2/ Equivalent to the sum of GNP plus external transfers. 
Table 5. Honduras: Composition of Fixed Capital Formation

(In millions of current lempiras)

\begin{tabular}{lrrrrr}
\hline & 1993 & 1994 & 1995 & 1996 & $\begin{array}{c}\text { Prel. } \\
1997\end{array}$ \\
\hline Gross fixed capital formation & $\mathbf{6 , 5 3 5}$ & $\mathbf{8 , 1 1 0}$ & $\mathbf{8 , 9 9 4}$ & $\mathbf{1 1 , 1 1 0}$ & $\mathbf{1 4 , 4 2 5}$ \\
& & & & & \\
Machinery and equipment & $\mathbf{2 , 6 1 7}$ & $\mathbf{4 , 2 4 5}$ & $\mathbf{4 , 4 7 7}$ & $\mathbf{6 , 2 9 6}$ & $\mathbf{8 , 6 8 5}$ \\
Public sector & 228 & 700 & 1,646 & $\mathbf{1 , 5 6 7}$ & 1,473 \\
Private sector & 2,389 & 3,545 & 2,831 & 4,729 & $\mathbf{7 , 2 1 2}$ \\
& & & & & \\
Construction & $\mathbf{3 , 9 1 8}$ & $\mathbf{3 , 8 6 5}$ & $\mathbf{4 , 5 1 7}$ & $\mathbf{4 , 8 1 4}$ & $\mathbf{5 , 7 4 0}$ \\
Public sector & 2,611 & 2,301 & 1,858 & 2,362 & 2,622 \\
Private sector & 1,307 & 1,564 & 2,659 & 2,452 & 3,118 \\
& & & & & \\
\hline
\end{tabular}

Sources: Central Bank of Honduras; and Fund staff estimates. 
Table 6. Honduras: Statistics on Selected Agricultural Products

(Area in thousands of hectares; production and exports in thousands of quintals; yield in quintals per hectare; values in millions of current lempiras)

\begin{tabular}{|c|c|c|c|c|c|}
\hline & 1993 & 1994 & 1995 & 1996 & $\begin{array}{l}\text { Prel. } \\
1997 \\
\end{array}$ \\
\hline \multicolumn{6}{|l|}{ Bananas } \\
\hline Area & 22 & 19 & 20 & 20 & 20 \\
\hline Yield & 948 & 897 & 956 & 1,127 & 1,042 \\
\hline $\begin{array}{l}\text { Volume of production } \\
\text { Of which }\end{array}$ & 20,751 & 17,049 & 19,110 & 22,534 & 20,848 \\
\hline Exported & 14,530 & 10,730 & 12,690 & 15,499 & 13,250 \\
\hline Gross value of production & 1,631 & 1,626 & 2,408 & 3,254 & 3,300 \\
\hline Value added & 379 & 409 & 635 & 1,023 & 1,017 \\
\hline \multicolumn{6}{|l|}{ Coffee } \\
\hline Area & 174 & 181 & 192 & 202 & 205 \\
\hline Yield & 15 & 14 & 15 & 16 & 16 \\
\hline $\begin{array}{l}\text { Volume of production } \\
\text { Of which }\end{array}$ & 2,665 & 2,597 & 2,919 & 3,210 & 3,217 \\
\hline Exported & 2,225 & 2,241 & 2,343 & 2,687 & 2,246 \\
\hline Gross value of production & 959 & 2,295 & 3,376 & 3,365 & 5,096 \\
\hline Value added & 908 & 2,270 & 2,136 & 2,827 & 4,281 \\
\hline \multicolumn{6}{|l|}{ Corn } \\
\hline Area & 415 & 382 & 417 & 386 & 390 \\
\hline Yield. & 32 & 29 & 36 & 30 & 34 \\
\hline Volume of production & 13,163 & 11,200 & 14,889 & 11,689 & 13,440 \\
\hline Gross value of production & 558 & 784 & 1,063 & 1,322 & 1,722 \\
\hline Value added & 351 & 494 & 670 & 833 & 1,085 \\
\hline \multicolumn{6}{|l|}{ Beans } \\
\hline Area & 58 & 99 & 96 & 92 & 108 \\
\hline Yield & 15 & 13 & 15 & 13 & 15 \\
\hline Volume of production & 857 & 1,310 & 1,426 & 1,195 & 1,643 \\
\hline Gross value of production & 159 & 287 & 228 & 556 & 791 \\
\hline Value added & 63 & 115 & 91 & 222 & 317 \\
\hline \multicolumn{6}{|l|}{ Rice } \\
\hline Area & 11 & 12 & 14 & 17 & 18 \\
\hline Yield & 77 & 87 & 88 & 78 & 62 \\
\hline Volume of production & 852 & 1,047 & 1,238 & 1,318 & 1,109 \\
\hline Gross value of production & 45 & 65 & 89 & 137 & 132 \\
\hline Value added & 15 & 22 & 29 & 45 & 44 \\
\hline \multicolumn{6}{|l|}{ Plantains } \\
\hline Area & 11 & 8 & 8 & 8 & 8 \\
\hline Yield & 346 & 538 & 527 & 559 & 567 \\
\hline $\begin{array}{l}\text { Volume of production } \\
\text { Of which }\end{array}$ & 3,908 & 4,303 & 4,218 & 4,469 & 4,536 \\
\hline Exported & 519 & 654 & 628 & 0 & $\mathbf{0}$ \\
\hline Gross value of production & 172 & 267 & 299 & 388 & 495 \\
\hline Value added & 105 & 180 & 182 & 222 & 282 \\
\hline
\end{tabular}


Table 6. Honduras: Statistics on Selected Agricultural Products

(Area in thousands of hectares; production and exports in thousands of quintals; yield in quintals per hectare; values in millions of current lempiras)

\begin{tabular}{|c|c|c|c|c|c|}
\hline & 1993 & 1994 & 1995 & 1996 & $\begin{array}{l}\text { Prel. } \\
1997\end{array}$ \\
\hline \multicolumn{6}{|l|}{ Sorghum } \\
\hline Area & 81 & 65 & 71 & 79 & 95 \\
\hline Yield & 25 & 18 & 19 & 24 & 22 \\
\hline Volume of production & 1,990 & 1,143 & 1,369 & 1,888 & 2,117 \\
\hline Gross value of production & 72 & 65 & 82 & 196 & 250 \\
\hline Value added & 39 & 36 & 45 & 108 & 137 \\
\hline \multicolumn{6}{|l|}{ Tobacco } \\
\hline Area & 9 & 7 & 7 & 7 & 7 \\
\hline Yield & 17 & 19 & 21 & 14 & 14 \\
\hline Volume of production & 146 & 136 & 149 & 99 & 97 \\
\hline \multicolumn{6}{|l|}{ Of which } \\
\hline Exported & 63 & 57 & 53 & 51 & 60 \\
\hline Gross value of production & 66 & 66 & 78 & 84 & 114 \\
\hline Value added & 41 & 36 & 55 & 46 & 62 \\
\hline \multicolumn{6}{|l|}{ Sugarcane } \\
\hline Area & 40 & 39 & 41 & 44 & 46 \\
\hline Yield & 1,586 & 1,611 & 1,645 & 1,794 & 1,806 \\
\hline Volume of production & 63,452 & 62,836 & 67,442 & 78,930 & 83,078 \\
\hline Gross value of production & 163 & 242 & 371 & 443 & 604 \\
\hline Value added & 118 & 165 & 211 & 267 & 364 \\
\hline \multicolumn{6}{|l|}{ African palm } \\
\hline Area & 32 & 25 & 26 & 27 & 29 \\
\hline Yield & 264 & 357 & 393 & 405 & 434 \\
\hline Volume of production & 8,443 & 8,931 & 10,224 & 10,936 & 12,577 \\
\hline Gross value of production & 121 & 129 & 226 & 358 & 445 \\
\hline Value added & 68 & 85 & 203 & 272 & 337 \\
\hline \multicolumn{6}{|l|}{ Melon } \\
\hline Area & 6 & 5 & 5 & 5 & 5 \\
\hline Yield & 351 & 549 & 452 & 522 & 592 \\
\hline Volume of production & 2,103 & 2,745 & 2,261 & 2,610 & 2,960 \\
\hline Gross value of production & 61 & 68 & 81 & 106 & 137 \\
\hline Value added & 31 & 37 & 44 & 56 & 71 \\
\hline \multicolumn{6}{|l|}{ Pineapple } \\
\hline Area & 3 & 3 & 3 & 3 & 3 \\
\hline Yield & 452 & 424 & 455 & 384 & 367 \\
\hline Volume of production & 1,357 & 1,271 & 1,365 & 1,151 & 1,100 \\
\hline Gross value of production & 89 & 98 & 123 & 167 & 202 \\
\hline Value added & 36 & 38 & 60 & 75 & 89 \\
\hline
\end{tabular}

Source: Central Bank of Honduras. 
Table 7. Honduras: Production and Prices of Basic Grains

(Production in thousands of quintals; prices in lempiras per quintal)

\begin{tabular}{|c|c|c|c|}
\hline & Production & $\begin{array}{c}\text { Wholesale } \\
\text { Prices }\end{array}$ & $\begin{array}{l}\text { Support Prices } \\
\text { Paid to } \\
\text { Producers } \\
\end{array}$ \\
\hline \multicolumn{4}{|l|}{ Corn } \\
\hline $1992-93$ & $13,163.0$ & 56.0 & 42.4 \\
\hline 1993-94 & $11,200.0$ & 95.5 & 70.0 \\
\hline 1994-95 & $14,889.0$ & 92.2 & 71.4 \\
\hline $1995-96$ & $11,689.0$ & 146.1 & 113.1 \\
\hline 1996-97 & $13,440.0$ & 161.0 & 128.1 \\
\hline \multicolumn{4}{|l|}{ Beans } \\
\hline 1992-93 & 857.0 & 251.9 & 185.0 \\
\hline $1993-94$ & $1,310.0$ & 257.4 & 219.0 \\
\hline 1994-95 & $1,426.0$ & 205.9 & 160.0 \\
\hline $1995-96$ & $1,195.0$ & 597.6 & 464.9 \\
\hline $1996-97$ & $1,643.0$ & 581.5 & 481.6 \\
\hline \multicolumn{4}{|l|}{ Rice } \\
\hline $1992-93$ & 852.0 & 163.9 & 53.0 \\
\hline 1993-94 & $1,047.0$ & 257.4 & 62.5 \\
\hline 1994-95 & $1,238.0$ & 236.8 & 71.9 \\
\hline 1995-96 & $1,318.0$ & 341.8 & 103.9 \\
\hline $1996-97$ & $1,109.0$ & 382.3 & 119.3 \\
\hline \multicolumn{4}{|l|}{ Sorghum } \\
\hline $1992-93$ & $1,990.0$ & 58.8 & 36.0 \\
\hline 1993-94 & $1,143.0$ & 79.0 & 57.0 \\
\hline $1994-95$ & $1,369.0$ & 84.0 & 60.0 \\
\hline $1995-96$ & $1,888.0$ & 140.4 & 104.0 \\
\hline $1996-97$ & $2,117.0$ & 155.5 & 117.9 \\
\hline
\end{tabular}

Sources: Honduran Institute for Agricultural Marketing (IHMA); and Central Bank of Honduras. 
Table 8. Honduras: Consumer Price Index

$(1978=100)$

\begin{tabular}{|c|c|c|c|c|c|c|}
\hline & Weight $1 /$ & 1993 & 1994 & 1995 & 1996 & 1997 \\
\hline \multicolumn{7}{|c|}{ (Period averages) 2/ } \\
\hline Total & 100.0 & 451.8 & 550.0 & 712.0 & 881.7 & $1,059.6$ \\
\hline \multicolumn{7}{|l|}{ By expenditure } \\
\hline Food & 41.2 & 439.5 & 559.7 & 718.1 & 895.3 & $1,072.4$ \\
\hline Housing & 30.6 & 408.2 & 483.2 & 633.5 & 783.7 & 904.7 \\
\hline Clothing & 9.1 & 602.6 & 671.9 & 826.8 & $1,008.9$ & $1,295.0$ \\
\hline Health care & 4.0 & 488.3 & 621.9 & 784.9 & 960.5 & $1,195.1$ \\
\hline Personal care & 3.0 & 384.4 & 465.5 & 605.6 & 751.3 & 917.0 \\
\hline Beverages and tobacco & 3.8 & 631.4 & 740.8 & 914.1 & $1,120.5$ & $1,322.0$ \\
\hline Transportation & 3.0 & 323.5 & 366.6 & 612.1 & 791.4 & 948.6 \\
\hline Other & 5.3 & 494.2 & 610.3 & 830.3 & $1,014.9$ & $1,308.3$ \\
\hline \multicolumn{7}{|l|}{ By region } \\
\hline Central & 47.5 & 437.6 & 523.8 & 674.8 & 818.8 & 978.2 \\
\hline Northern & 40.2 & 468.2 & 581.3 & 758.7 & 957.5 & $1,161.5$ \\
\hline Southern & 4.7 & 453.7 & 549.0 & 682.5 & 847.8 & 993.0 \\
\hline Eastern & 5.9 & 454.3 & 549.4 & 718.5 & 893.9 & $1,059.8$ \\
\hline Western & 1.9 & 449.3 & 545.2 & 707.6 & 897.2 & $1,102.4$ \\
\hline \multicolumn{7}{|c|}{ (End of period) $3 /$} \\
\hline Total & 100.0 & 475.7 & 613.2 & 777.5 & 974.3 & $1,098.8$ \\
\hline \multicolumn{7}{|l|}{ By expenditure } \\
\hline Food & 41.2 & 465.6 & 631.6 & 771.2 & 992.6 & $1,083.8$ \\
\hline Housing & 30.6 & 427.6 & 537.7 & 699.9 & 849.8 & 944.2 \\
\hline Clothing & 9.1 & 628.3 & 715.4 & 903.5 & $1,160.2$ & $1,388.0$ \\
\hline Health care & 4.0 & 532.2 & 688.9 & 860.2 & $1,039.9$ & $1,284.8$ \\
\hline Personal care & 3.0 & 416.3 & 506.7 & 652.9 & 820.9 & 963.2 \\
\hline Beverages and tobacco & 3.8 & 653.3 & 869.2 & 1077.8 & $1,172.4$ & $1,450.7$ \\
\hline Transportation & 3.0 & 331.0 & 416.9 & 648.2 & 914.0 & 948.5 \\
\hline Other & 5.3 & 514.4 & 659.8 & 914.1 & $1,176.9$ & $1,380.8$ \\
\hline \multicolumn{7}{|l|}{ By region } \\
\hline Central & 47.5 & 458.9 & 577.8 & 735.7 & 901.2 & $1,006.0$ \\
\hline Northern & 40.2 & 497.1 & 654.0 & 832.9 & $1,066.3$ & $1,209.4$ \\
\hline Southern & 4.7 & 474.2 & 607.0 & 732.3 & 949.5 & $1,059.0$ \\
\hline Eastern & 5.9 & 468.2 & 622.9 & 778.1 & 967.2 & $1,107.0$ \\
\hline Western & 1.9 & 469.8 & 621.0 & 758.6 & 982.1 & $1,149.3$ \\
\hline
\end{tabular}

Source: Central Bank of Honduras.

1/ In percent.

2/ Average over 12-month period ended in December.

3/ Data refers to the month of December. 
Table 9. Honduras: Wholesale Price Index

$(1978 \approx 100)$

\begin{tabular}{|c|c|c|c|c|c|c|c|c|}
\hline & Weight $1 /$ & 1991 & 1992 & 1993 & 1994 & 1995 & 1996 & 1997 \\
\hline \multicolumn{9}{|c|}{ (Period average) $2 /$} \\
\hline Total & 100.0 & 373.8 & 411.5 & 463.9 & 585.8 & 752.8 & 926.2 & $1,062.4$ \\
\hline National & 67.2 & 358.9 & 404.7 & 466.3 & 590.7 & 784.5 & 968.9 & $1,110,0$ \\
\hline Agriculture and livestock & 28.2 & 359.1 & 386.7 & 488.5 & 610.2 & 758.3 & 933.1 & $1,046.6$ \\
\hline Agriculture & 10.9 & 317.5 & 275.6 & 349.1 & 506.2 & 597.9 & 924.7 & $1,010.0$ \\
\hline Livestock & 10.3 & 364.3 & 378.4 & 416.9 & 537.9 & 691.2 & 783.0 & 950.8 \\
\hline Other & 7.0 & 415.1 & 568.7 & 805.4 & 873.9 & $1,101.0$ & $1,162.8$ & $1,240.9$ \\
\hline Industrial & 39.1 & 358.8 & 417.7 & 450.2 & 576.6 & 803.4 & 994.7 & $1,155.8$ \\
\hline Food & 12.3 & 307.9 & 352.0 & 376.8 & 506.0 & 712.7 & 842.1 & 955.2 \\
\hline Beverages and tobacco & 7.2 & 385.0 & 498.1 & 542.0 & 635.9 & 835.7 & $1,006.1$ & $1,200.7$ \\
\hline Construction material & 4.0 & 297.9 & 303.6 & 360.7 & 537.5 & 740.6 & 866.2 & 999.4 \\
\hline Textile & 2.9 & 372.6 & 457.1 & 444.2 & 546.4 & 795.1 & 916.3 & $1,105.1$ \\
\hline Clothing & 2.1 & 333.9 & 389.5 & 387.8 & 455.8 & 609.7 & 760.2 & 892.2 \\
\hline Chemical & 3.3 & 342.4 & 546.8 & 632.0 & 805.8 & $1,249.4$ & $1,628.7$ & $1,924.6$ \\
\hline Oil products & 4.6 & 506.3 & 479.1 & 502.8 & 647.8 & 830.8 & $1,219.9$ & $1,394.0$ \\
\hline Other & 2.7 & 384.7 & 404.3 & 415.0 & 521.8 & 786.6 & 951.8 & $1,089.3$ \\
\hline Imported & 32.8 & 404.4 & 425.5 & 458.4 & $\mathbf{5 7 5 . 8}$ & 687.7 & 838.6 & 964.6 \\
\hline Food & 6.4 & 381.3 & 424.0 & 479.1 & 596.1 & 693.5 & 903.8 & $1,087.6$ \\
\hline Beverages and tobacco & 0.6 & 517.0 & 612.0 & 626.8 & 683.7 & 658.4 & 839.4 & $1,143,4$ \\
\hline Textile & 4.9 & 314.0 & 321.2 & 345.1 & 451.1 & 520.9 & 546.7 & 594.8 \\
\hline Chemical & 9.8 & 477.3 & 474.9 & 503.0 & 603.6 & 731.1 & 903.1 & 965.4 \\
\hline Pharmaceutic & 3.6 & 323.3 & 412.4 & 452.7 & 590.3 & 703.6 & 844.9 & $1,134.9$ \\
\hline Other & 7.5 & 418.0 & 422.0 & 445.8 & 589.5 & 730.0 & 886.3 & $1,003.4$ \\
\hline \multicolumn{9}{|c|}{ (End of period) $3 /$} \\
\hline Total & 100.0 & 388.7 & 426.4 & 485.9 & 856.2 & 795.6 & $1,007.4$ & $1,074.1$ \\
\hline National & 67.2 & $\mathbf{3 7 4 . 0}$ & 425.0 & 483.7 & 671.9 & 824.2 & $1,050.7$ & $1,114.0$ \\
\hline Agriculture and livestock & 28.2 & 355.7 & 423.8 & 506.1 & 666.9 & 783.7 & 983.8 & $1,023.2$ \\
\hline Agriculture & 10.9 & 250.1 & 278.4 & 354.1 & 552.9 & 607.1 & 989.2 & 934.8 \\
\hline Livestock & 10.3 & 386.9 & 383.2 & 448.6 & 595.9 & 715.2 & 847.6 & 987.4 \\
\hline Other & 7.0 & 472.6 & 704.8 & 822.0 & 943.9 & $1,152.9$ & $1,172.4$ & $1,210.4$ \\
\hline Industrial & 39.1 & 387.1 & 425.9 & 467.5 & 675.6 & 853.4 & $1,099.1$ & $1,179.6$ \\
\hline Food & 12.3 & 326.5 & 357.7 & 392.0 & 611.4 & 730.3 & 809.2 & 983.9 \\
\hline Beverages and tobacco & 7.2 & 439.1 & 506.6 & 557.7 & 749.1 & 940.6 & $1,019.3$ & $1,289.5$ \\
\hline Construction material & 4.0 & 291.4 & 308.8 & 383.1 & 583.8 & 756.5 & 973.3 & $1,008.7$ \\
\hline Textile & 2.9 & 439.4 & 462.8 & 467.6 & 609.3 & 816.3 & $1,037.1$ & $1,103.0$ \\
\hline Clothing & 2.1 & 358.0 & 361.5 & 419.1 & 509.5 & 641.2 & 827.8 & 906.9 \\
\hline Chemical & 3.3 & 408.4 & 591.0 & 664.8 & 853.1 & $1,391.0$ & $1,852.6$ & $1,947.5$ \\
\hline Oil products & 4.6 & 502.7 & 483.0 & 510.7 & 803.4 & 892.3 & $1,548.2$ & $1,328.7$ \\
\hline Other & 2.7 & 410.5 & 405.7 & 417.9 & 870.4 & 802.5 & $1,032.9$ & $1,126.5$ \\
\hline Imported & 32.8 & 418.9 & 429.2 & 490.5 & 624.2 & 736.9 & 918.4 & 992.1 \\
\hline Food & 6.4 & 408.1 & 437.1 & 508.9 & 635.9 & 730.3 & $1,000.5$ & $1,093.1$ \\
\hline Beverages and tobacco & 0.6 & 517.0 & 612.0 & 645.0 & 651.2 & 660.7 & $1,191.7$ & $1,141.8$ \\
\hline Textile & 4.9 & 320.8 & 319.7 & 364.9 & 501.9 & 536.9 & 576.0 & 626.6 \\
\hline Chemical & 9.8 & 490.8 & 476.2 & $\$ 27.0$ & 654.3 & 814.1 & 956.1 & 963.2 \\
\hline Pharmaceutic & 3.6 & 334.3 & 418.6 & 506.8 & 638.1 & 732.6 & $1,010.8$ & $1,305.9$ \\
\hline Other & 7.5 & 431.3 & 423.1 & 489.1 & 645.9 & 781.0 & 956.1 & $1,019.2$ \\
\hline
\end{tabular}

Source: Central Bank of Honduras.

1/ In percent.

2/ Average over 12-month period ended in December.

3/ Data refers to the month of December. 
Table 10. Honduras: Average Daily Minimum Wage by Sector

\begin{tabular}{|c|c|c|c|c|c|}
\hline & 1993 & 1994 & 1995 & 1996 & 1997 \\
\hline \multicolumn{6}{|c|}{ (In lempiras) } \\
\hline Annual average & 16.9 & 17.9 & 21.2 & 25.3 & $\mathbf{3 3 . 5}$ \\
\hline Agriculture and related sectors & 13.1 & 13.7 & 16.7 & 20.3 & 27.5 \\
\hline Mining of metals & 20.8 & 22.6 & 26.0 & 30.6 & 39.7 \\
\hline Other mining & 16.1 & 16.9 & 19.5 & 21.9 & 28.5 \\
\hline Manufacturing & 13.8 & 14.4 & 17.9 & 22.0 & 28.5 \\
\hline Construction & 12.6 & 13.2 & 16.7 & 21.7 & 28.5 \\
\hline Commerce, hotels, and restaurants & 14.4 & 15.1 & 18.6 & 22.0 & 28.5 \\
\hline Transport & 15.6 & 16.3 & 19.8 & 24.0 & 30.0 \\
\hline Financial services & 16.5 & 17.9 & 21.0 & 24.2 & 31.0 \\
\hline Other services & 13.7 & 14.3 & 17.9 & 21.7 & 38.5 \\
\hline Dockage services & 20.0 & 20.7 & 24.5 & 29.1 & 39.7 \\
\hline Petroleum refining & 20.0 & 20.7 & 24.5 & 29.1 & 39.7 \\
\hline Railroad repairing & 20.0 & 20.7 & 24.5 & 29.1 & 39.7 \\
\hline Banana exporting & 20.0 & 20.7 & 24.5 & 29.1 & 39.7 \\
\hline \multicolumn{6}{|c|}{ (Annual percentage increase) } \\
\hline Annual average & 12.7 & 4.7 & 19.9 & 19.0 & 32.5 \\
\hline Agriculture and related sectors & 12.3 & 4.4 & 21.9 & 21.4 & 35.6 \\
\hline Mining of metals & 19.5 & 8.4 & 15.0 & 17.6 & 29.7 \\
\hline Other mining & 12.0 & 4.5 & 15.8 & 12.4 & 29.9 \\
\hline Manufacturing & 12.1 & 4.4 & 24.4 & 23.1 & 29.4 \\
\hline Construction & 15.8 & 5.4 & 26.0 & 30.2 & 31.3 \\
\hline Commerce, hotels, and restaurants & 12.2 & 4.4 & 23.5 & 18.4 & 29.3 \\
\hline Transport & 11.9 & 4.4 & 21.7 & 21.0 & 25.1 \\
\hline Financial services & 19.3 & 8.5 & 17.8 & 15.0 & 28.2 \\
\hline Other services & 12.0 & 4.4 & 24.7 & 21.2 & 31.6 \\
\hline Dockage services & 10.6 & 3.5 & 18.6 & 18.7 & 36.3 \\
\hline Petroleum refining & 10.6 & 3.5 & 18.6 & 18.7 & 36.3 \\
\hline Railroad repairing & 10.6 & 3.5 & 18.6 & 18.7 & 36.3 \\
\hline Banana exporting & 10.6 & 3.5 & 18.6 & 18.7 & 36.3 \\
\hline Consumer price index & 10.7 & 21.7 & 29.5 & 23.8 & 20.2 \\
\hline \multicolumn{6}{|l|}{ Memorandum item: } \\
\hline Annual average in U.S. dollars & 2.6 & 2.1 & 2.3 & 2.2 & 2.6 \\
\hline
\end{tabular}

Source: Central Bank of Honduras. 
Table 11. Honduras: Total Labor Remuneration by Sector

(In millions of current lempiras)

\begin{tabular}{lrrrrr}
\hline & 1993 & 1994 & 1995 & 1996 & 1997 \\
\hline Total & $\mathbf{9 , 1 9 7}$ & $\mathbf{1 1 , 0 3 6}$ & $\mathbf{1 4 , 3 0 4}$ & $\mathbf{1 7 , 7 0 8}$ & $\mathbf{2 0 , 3 5 2}$ \\
& & & & & \\
Agriculture and related sectors & 1,818 & 2,294 & 3,163 & $\mathbf{4 , 1 5 6}$ & 4,632 \\
Mining & 164 & 213 & 234 & 271 & $\mathbf{3 0 2}$ \\
Manufacturing & 1,683 & 1,840 & 2,356 & 2,733 & 3,098 \\
Construction & 732 & 743 & 918 & 1,076 & 1,230 \\
Utilities & 118 & 169 & 335 & 344 & 414 \\
Transport and communication & 686 & $\mathbf{7 2 6}$ & $\mathbf{7 8 1}$ & $\mathbf{8 6 0}$ & 1,009 \\
Commercial services & $\mathbf{8 5 8}$ & $\mathbf{8 5 8}$ & 1,365 & 1,696 & 1,870 \\
Financial services & 577 & 745 & 934 & 1,232 & 1,496 \\
Housing services & $\mathbf{1 4 1}$ & 174 & 206 & 265 & 289 \\
Public administration & 997 & 1,136 & 1,538 & 1,650 & 2,067 \\
Other services & 1,598 & 2,138 & 2,474 & 3,425 & 3,945 \\
$\quad$ Public services & 1,068 & 1,319 & 1,625 & 2,250 & 2,591 \\
Private services & $\mathbf{5 3 0}$ & $\mathbf{8 1 9}$ & $\mathbf{8 4 9}$ & $\mathbf{1 , 1 7 5}$ & $\mathbf{1 , 3 5 4}$ \\
& & & & & \\
\hline
\end{tabular}

Source: Central Bank of Honduras. 
Table 12. Honduras: Labor Force by Sector

(In percent of total labor force)

\begin{tabular}{lrrrrr}
\hline & 1993 & 1994 & 1995 & 1996 & 1997 \\
\hline Total & 100.0 & 100.0 & 100.0 & 100.0 & 100.0 \\
Primary production & 44.7 & 43.8 & 42.9 & 42.0 & 41.1 \\
Agriculture and related sectors & 44.4 & 43.5 & 42.7 & 41.8 & 40.9 \\
Mining & 0.3 & 0.3 & 0.2 & 0.2 & 0.2 \\
Secondary production & 18.7 & 18.9 & 19.2 & 19.4 & 19.6 \\
Manufacturing & 11.8 & 11.7 & 11.8 & 11.8 & 11.7 \\
Construction & 6.2 & 6.4 & 6.6 & 6.8 & 7.0 \\
Utilities & 0.7 & 0.8 & 0.8 & 0.8 & 0.9 \\
& & & & & \\
Services & 36.6 & 37.3 & 37.9 & 38.6 & 39.3 \\
Transport and communications & 2.8 & 2.8 & 2.8 & 2.8 & 2.8 \\
Commercial services & 10.5 & 10.7 & 10.8 & 10.9 & 11.0 \\
Financial services & 1.9 & 2.0 & 2.0 & 2.1 & 2.2 \\
Other services & 21.4 & 21.8 & 22.3 & 22.8 & 23.3 \\
& & & & & \\
Memorandum item: & & & & & \\
Labor force as a percent & & & & & \\
$\quad$ of total population & 31.5 & 31.8 & 32.1 & 32.4 & 32.7 \\
\hline
\end{tabular}

Source: Central Bank of Honduras. 
Table 13. Honduras: Consolidated Operations of the Nonfinancial Public Sector

(In millions of lempiras)

\begin{tabular}{|c|c|c|c|c|c|}
\hline & 1993 & 1994 & 1995 & 1996 & $\begin{array}{l}\text { Prel. } \\
1997 \\
\end{array}$ \\
\hline \multicolumn{6}{|c|}{ I. Central Government } \\
\hline Total revenue & 3,964 & 4,709 & 6,979 & 8,027 & 10,318 \\
\hline Current revenue & 3,847 & 4,589 & 6,952 & 8,006 & 10,305 \\
\hline Tax revenue & 3,609 & 4,383 & 6,691 & 7,542 & 9,667 \\
\hline Direct taxes & 1,167 & 1,144 & 1,798 & 2,034 & 2,508 \\
\hline Property and income & 1,082 & 1,101 & 1,757 & 1,968 & 2,410 \\
\hline Other $1 /$ & 85 & 43 & 41 & 66 & 98 \\
\hline Indirect taxes & 2,442 & 3,239 & 4,678 & 5,469 & 7,159 \\
\hline Goods and services & 1,384 & 1,845 & 2,552 & 3,114 & 3,956 \\
\hline Sales tax & 697 & 885 & 1,331 & 1,698 & 2,270 \\
\hline Other & 687 & 960 & 1,221 & 1,416 & 1,686 \\
\hline International trade & 1,057 & 1,295 & 1,751 & 1,804 & 2,155 \\
\hline Import & 986 & 1,185 & 1,430 & 1,706 & 2,066 \\
\hline Export 2/ & 71 & 110 & 321 & 98 & 89 \\
\hline Petroleum derivatives & 0 & 98 & 373 & 548 & 1,046 \\
\hline Other & 1 & 1 & 2 & 3 & 2 \\
\hline Nontax revenue & 70 & 76 & 107 & 154 & 226 \\
\hline Transfers & 168 & 130 & 154 & 310 & 412 \\
\hline Capital revenue & 117 & 120 & 27 & 21 & 13 \\
\hline Total primary expenditure & 5,381 & 4,967 & 6,273 & 7,297 & 9,211 \\
\hline Current primary expenditure & 3,221 & 3,063 & 3,959 & 5,441 & 6,980 \\
\hline Wages and salaries & 1,524 & 1,791 & 2,317 & 2,865 & 3,417 \\
\hline Social security contributions & 130 & 155 & 180 & 245 & 293 \\
\hline Goods and services & 628 & 607 & 744 & 1,089 & 1,527 \\
\hline Current transfers & 939 & 510 & 718 & 1,242 & 1,743 \\
\hline Rest of general government & 343 & 283 & 530 & 756 & 951 \\
\hline Public enterprises & 0 & 0 & 13 & 0 & 88 \\
\hline Private sector & 572 & 200 & 141 & 439 & 631 \\
\hline Other & 24 & 27 & 34 & 48 & 73 \\
\hline Capital expenditure & 2,126 & 1,505 & 1,791 & 1,599 & 2,194 \\
\hline Fixed capital formation & 1,503 & 995 & 1,218 & 1,114 & 1,608 \\
\hline Capital transfers & 623 & 510 & 573 & 485 & 586 \\
\hline Rest of general government & 276 & 319 & 298 & 308 & 437 \\
\hline Public enterprise & 147 & 179 & 269 & 175 & 148 \\
\hline Private sector & 200 & 12 & 6 & 2 & 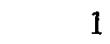 \\
\hline Net lending & 34 & 399 & 523 & 257 & 37 \\
\hline Rest of general government & 2 & 30 & 27 & 25 & 0 \\
\hline Public enterprise & 32 & 369 & 496 & 232 & 37 \\
\hline Current primary balance & 626 & 1,526 & 2,993 & 2,565 & $\mathbf{3 , 3 2 5}$ \\
\hline Primary balance & $-1,417$ & -258 & 706 & 730 & 1,107 \\
\hline Interest obligations & 979 & 1,458 & 1,510 & 1,966 & 2,685 \\
\hline External 3/ & 745 & 1,143 & 1,053 & 1,296 & 1,501 \\
\hline Internal & 233 & 315 & 457 & 671 & 1,184 \\
\hline Current balance & -356 & 45 & 1,196 & 2,565 & 3,325 \\
\hline Overall balance & $-2,398$ & $-1,776$ & $-1,211$ & $-1,236$ & $-1,578$ \\
\hline
\end{tabular}


Table 13. Honduras: Consolidated Operations of the Nonfinancial Public Sector

(In millions of lempiras)

\begin{tabular}{|c|c|c|c|c|c|}
\hline & 1993 & 1994 & 1995 & 1996 & $\begin{array}{l}\text { Prel. } \\
1997 \\
\end{array}$ \\
\hline \multicolumn{6}{|c|}{ II. Rest of General Government } \\
\hline Total revenue & 1,477 & 1,881 & 2,278 & 2,574 & 3,834 \\
\hline Current revenue & 1,172 & 1,368 & 1,922 & 2,177 & 3,065 \\
\hline Tax revenue & 197 & 212 & 206 & 283 & 346 \\
\hline Contributions to social security & 433 & 512 & 624 & 684 & 979 \\
\hline Private sector & 240 & 299 & 376 & 417 & 588 \\
\hline Central government & 133 & 158 & 176 & 184 & 278 \\
\hline Rest of general government & 22 & 18 & 24 & 27 & 38 \\
\hline Public enterprises & 38 & 37 & 49 & 56 & 76 \\
\hline Interest eamings & 195 & 218 & 308 & 404 & 570 \\
\hline Current transfers & 302 & 309 & 508 & 448 & 692 \\
\hline Central government & 299 & 306 & 503 & 448 & 692 \\
\hline Public enterprises & 3 & 3 & 5 & 0 & 0 \\
\hline Private sector & 0 & 0 & 0 & 0 & 0 \\
\hline Other nontax revenue & 114 & 178 & 229 & 323 & 414 \\
\hline Change in accounts receivable (increase -) & -69 & -62 & 47 & 37 & 64 \\
\hline Capital revenue & 305 & 513 & 355 & 396 & 769 \\
\hline Central government transfers & 276 & 466 & 323 & 360 & 630 \\
\hline Other & 29 & 47 & 33 & 37 & 139 \\
\hline Total expenditure & 1,445 & 1,958 & 2,121 & 2,394 & 3,650 \\
\hline Current expenditure & 852 & 983 & 1,059 & 1,283 & 2,066 \\
\hline Wages and salaries & 315 & 335 & 429 & 539 & 596 \\
\hline Goods and services & 144 & 154 & 183 & 194 & 237 \\
\hline Interest payments & 29 & 28 & 21 & 25 & 65 \\
\hline Contribution to social security & 19 & 18 & 24 & 26 & 37 \\
\hline Current transfers & 361 & 359 & 384 & 488 & 1,130 \\
\hline To private sector & 361 & 354 & 384 & 480 & 1,123 \\
\hline Other & 0 & 5 & 0 & 8 & 7 \\
\hline Change in accounts payable & -16 & 90 & 18 & 11 & 2 \\
\hline Capital expenditure and net lending & 593 & 976 & 1,062 & 1,111 & 1,584 \\
\hline Fixed capital formation & 484 & 880 & 968 & 817 & 1,075 \\
\hline Other & 15 & 0 & 0 & 4 & 41 \\
\hline Net lending & 94 & 95 & 93 & 291 & 469 \\
\hline Primary balance & -135 & -267.7 & -130.7 & -199.0 & -322 \\
\hline Current account balance & 320 & 384.8 & 863.0 & 894.4 & 999 \\
\hline Overall balance & 32 & -77.4 & 156.6 & 179.9 & 184 \\
\hline
\end{tabular}


Table 13. Honduras: Consolidated Operations of the Nonfinancial Public Sector (In millions of lempiras)

\begin{tabular}{|c|c|c|c|c|c|}
\hline & 1993 & 1994 & 1995 & 1996 & $\begin{array}{l}\text { Prel. } \\
1997 \\
\end{array}$ \\
\hline \multicolumn{6}{|c|}{ III. General Government } \\
\hline Total primary revenue & 4,375 & $\mathbf{5 , 2 1 2}$ & $\mathbf{7 , 4 0 4}$ & 8,633 & 11,153 \\
\hline Current primary revenue & 4,229 & 5,045 & 7,345 & 8,575 & 11,001 \\
\hline Tax revenue & 3,805 & 4,596 & 6,897 & 7,825 & 10,013 \\
\hline Nontax revenue & 184 & 254 & 336 & 477 & 640 \\
\hline \multicolumn{6}{|l|}{ Contributions to social } \\
\hline security institutions 4 / & 278 & 337 & 424 & 473 & 664 \\
\hline From state enterprises & 38 & 37 & 49 & 56 & 76 \\
\hline From private sector & 240 & 299 & 376 & 417 & 588 \\
\hline Current transfers & 171 & 133 & 159 & 310 & 412 \\
\hline From state enterprises & 171 & 133 & 159 & 310 & 412 \\
\hline Change in accounts receivables (increase -) & -69 & -62 & 47 & 37 & 64 \\
\hline Capital revenue & 146 & 167 & 60 & 58 & 152 \\
\hline Total expenditure & 6,071 & 5,923 & $\mathbf{7 , 3 1 6}$ & 8,733 & 11,145 \\
\hline Current expenditure & 3,596 & 3,540 & 4,290 & 5,980 & 7,960 \\
\hline Wages and salaries & 1,839 & 2,126 & 2,746 & 3,404 & 4,013 \\
\hline Goods and services & 772 & 761 & 927 & 1,283 & 1,764 \\
\hline Current transfers & 957 & 586 & 572 & 974 & 1,922 \\
\hline To private sector & 933 & 554 & 525 & 919 & 1,753 \\
\hline To abroad & 24 & 32 & 34 & 56 & 80 \\
\hline Adjustment for current transfers & 44 & -23 & 27 & 308 & 259 \\
\hline Capital expenditure & 2,349 & 1,919 & 2,437 & 2,230 & 2,679 \\
\hline Fixed capital formation & 1,987 & 1,875 & 2,186 & 2,101 & 2,683 \\
\hline Inventory changes & 15 & 0 & 0 & 4 & 41 \\
\hline Capital transfers & 347 & 191 & 275 & 177 & 149 \\
\hline To state enterprises & 147 & 179 & 269 & 175 & 148 \\
\hline To private sector & 200 & 12 & 6 & 2 & 1 \\
\hline Adjustment for capital transfers & 0 & -147 & -25 & -52 & -193 \\
\hline Net lending & 126 & 464 & 589 & 523 & 506 \\
\hline To state enterprises & 32 & 369 & 496 & 232 & 37 \\
\hline Pension funds lending to members & 94 & 95 & 93 & 291 & 469 \\
\hline Primary current balance & 634 & $\mathbf{1 , 5 0 5}$ & 3,054 & 2,595 & 3,041 \\
\hline Primary balance & $-1,696$ & -711 & 88 & -100 & 8 \\
\hline Interest revenue & 195 & 218 & 308 & 404 & 570 \\
\hline Interest obligations & 1,007 & 1,486 & 1,531 & 1,991 & 2,750 \\
\hline External & 745 & 1,143 & 1,053 & 1,296 & 1,501 \\
\hline Internal & 262 & 343 & 478 & 695 & 1,248 \\
\hline Current balance & -178 & 237 & 1,831 & 1,007 & 861 \\
\hline Overall balance & $-2,507$ & $-1,979$ & $-1,135$ & $-1,687$ & $-2,172$ \\
\hline
\end{tabular}


Table 13. Honduras: Consolidated Operations of the Nonfinancial Public Sector

(In millions of lempiras)

\begin{tabular}{|c|c|c|c|c|c|}
\hline & 1993 & 1994 & 1995 & 1996 & $\begin{array}{l}\text { Prel. } \\
1997 \\
\end{array}$ \\
\hline \multicolumn{6}{|c|}{ IV. Nonfinancial Public Enterprises } \\
\hline Operating revenue & 1,699 & 2,120 & 2,895 & 4,299 & 5,080 \\
\hline Sale of goods and services & 1,703 & 2,126 & 3,144 & 4,267 & 4,986 \\
\hline Interest received & 0 & 5 & 8 & 81 & 120 \\
\hline Other $5 /$ & -4 & -12 & -257 & 49 & -26 \\
\hline Operating expenditure & 599 & 1,211 & 2,179 & 2,984 & 2,910 \\
\hline Wages and salaries & 262 & 328 & 456 & 569 & 651 \\
\hline Goods and services & 245 & 442 & 1,157 & 1,575 & 1,715 \\
\hline Interest & 284 & 466 & 537 & 617 & 440 \\
\hline External & 225 & 309 & 488 & 543 & 418 \\
\hline Domestic & 60 & 157 & 49 & 75 & 23 \\
\hline Other $6 /$ & -192 & -25 & 30 & 222 & 104 \\
\hline Operating balance & 1,100 & 909 & 716 & 1,316 & $\mathbf{2 , 1 7 0}$ \\
\hline Net current transfers & -224 & -196 & -178 & -22 & -43 \\
\hline Transfers receipts & 0 & 3 & 0 & 232 & 314 \\
\hline From central government & 0 & 3 & 0 & 232 & 314 \\
\hline Transfers and tax payments & 224 & 199 & 178 & 253 & 357 \\
\hline To central government & 193 & 164 & 146 & 210 & 270 \\
\hline To rest of general government & 16 & 12 & 11 & 13 & 17 \\
\hline To private sector & 15 & 23 & 20 & 29 & 70 \\
\hline Current account balance & 876 & 713 & 538 & 1,294 & 2,127 \\
\hline Net capital revenue & 285 & 191 & 348 & 232 & 116 \\
\hline Capital revenue & 2 & 75 & 0 & 70 & 0 \\
\hline Capital tranfers receipts & 288 & 116 & 348 & 161 & 116 \\
\hline From central government & 288 & 116 & 253 & 161 & 116 \\
\hline From abroad & 0 & 0 & 95 & 0 & 0 \\
\hline Capital transfers payments & 6 & 0 & 0 & 0 & 0 \\
\hline Capital expenditure and net lending & 968 & 1,244 & 1,287 & 1,611 & 1,280 \\
\hline Fixed investment & 852 & 1,126 & 1,318 & 1,554 & 1,207 \\
\hline Other & 116 & 118 & -31 & 57 & 71 \\
\hline Net lending & 0 & 0 & 0 & 0 & 2 \\
\hline Primary balance & 477 & 121 & 128 & 450 & 1,283 \\
\hline Overall balance & 193 & -340 & -402 & -86 & 963 \\
\hline \multicolumn{6}{|c|}{ V. Consolidated Nonfinancial Public Sector } \\
\hline Total revenue & 6,001 & 7,448 & 10,690 & 13,151 & 16,313 \\
\hline Current revenue & 5,859 & 7,201 & 10,543 & 13,111 & 16,292 \\
\hline Tax revenue & 3,805 & 4,596 & 6,897 & 7,825 & 10,013 \\
\hline Nontax revenue & 115 & 192 & 383 & 513 & 704 \\
\hline \multicolumn{6}{|l|}{ Private sector contributions to } \\
\hline social security institutions $4 /$ & 240 & 299 & 376 & 417 & 588 \\
\hline Operating revenue of public enterprises & 1,699 & 2,114 & 2,887 & 4,356 & 4,987 \\
\hline Capital revenue & 142 & 247 & 147 & 40 & 21 \\
\hline
\end{tabular}


Table 13. Honduras: Consolidated Operations of the Nonfinancial Public Sector (In millions of lempiras)

\begin{tabular}{|c|c|c|c|c|c|}
\hline & 1993 & 1994 & 1995 & 1996 & $\begin{array}{l}\text { Prel. } \\
1997 \\
\end{array}$ \\
\hline Total expenditure $2 /$ & 7,299 & 7,602 & 9,816 & 12,089 & 14,422 \\
\hline Current primary expenditure & 3,948 & 4,336 & 5,940 & 8,008 & 9,914 \\
\hline Wages and salaries & 2,101 & 2,454 & 3,201 & 3,984 & 4,662 \\
\hline Goods and services & 1,017 & 1,203 & 2,084 & 2,852 & 3,483 \\
\hline Current transfers & 1,038 & 614 & 606 & 980 & 1,807 \\
\hline To private sector & 947 & 575 & 539 & 927 & 1,817 \\
\hline To abroad & 25 & 35 & 40 & 75 & 98 \\
\hline Adjustment for current transfers & 66 & 4 & 27 & -22 & -108 \\
\hline Capital expenditure & 3,258 & 3,171 & 3,782 & 3,790 & 4,038 \\
\hline Fixed capital formation & 2,894 & 3,002 & 3,524 & 3,606 & 3,809 \\
\hline Capital transfers & 59 & -72 & -3 & -36 & -160 \\
\hline Capital transfers to private sector & 200 & 12 & 6 & 2 & 1 \\
\hline Adjustment for capital transfers & -141 & -84 & -9 & -38 & -161 \\
\hline Other capital expenditure & 305 & 241 & 261 & 220 & 390 \\
\hline Net lending & 94 & 95 & 94 & 291 & 471 \\
\hline Pension funds loans to members & 94 & 95 & 93 & 291 & 469 \\
\hline Primary current balance & 1,912 & 2,866 & 4,603 & 5,103 & 6,378 \\
\hline Primary balance & $-1,298$ & -153 & 874 & 1,062 & 1,891 \\
\hline Interest revenue & 195 & 213 & 301 & 340 & 416 \\
\hline Interest obligations & 1,291 & 1,952 & 2,068 & 2,650 & 3,241 \\
\hline External & 970 & 1,452 & 1,541 & 1,880 & 1,970 \\
\hline Internal & 321 & 500 & 527 & 770 & 1,271 \\
\hline Current balance & 816 & 1,127 & 2,835 & 2,793 & 3,553 \\
\hline Overall balance & $-2,394$ & $-1,893$ & -893 & $-1,249$ & -934 \\
\hline Identified financing & 2,309 & 1,926 & 922 & 1,525 & 932 \\
\hline Net foreign financing & 1,976 & 1,483 & 1,733 & 1,789 & 1,868 \\
\hline Net foreign borrowing & 1,793 & 1,235 & 982 & 1,112 & 1,204 \\
\hline Disbursements & 2,332 & 2,174 & 3,012 & 3,263 & 3,396 \\
\hline Amortization & $-1,107$ & $-1,575$ & $-2,522$ & $-2,151$ & $-2,192$ \\
\hline Debt relief & 569 & 635 & 492 & 398 & 358 \\
\hline Change in arrears & -84 & -109 & 501 & 35 & -151 \\
\hline Foreign grants & 321 & 352 & 259 & 244 & 457 \\
\hline \multirow{2}{*}{$\begin{array}{l}\text { Change in government bonds held by } \\
\text { international organizations }\end{array}$} & & & & & \\
\hline & -54 & 6 & -9 & & \\
\hline Net domestic financing & 334 & 443 & -811 & -264 & -936 \\
\hline Banking system & 149 & 377 & -881 & -735 & $-1,873$ \\
\hline Central bank & 154 & 125 & -670 & -292 & -604 \\
\hline Rest of banking system & -5 & 251 & -210 & -443 & $-1,269$ \\
\hline Private sector bonds & 28 & 7 & 70 & 221 & 627 \\
\hline Transfers from ESF and other & 157 & 60 & 0 & 250 & 310 \\
\hline Statistical discrepancy & -113 & -181 & 29 & 276 & -3 \\
\hline
\end{tabular}

Source: Ministry of Finance.

1/ Includes taxes in the revaluation of assets in 1993 and on net assets in 1994-1997.

2/ Excludes interest obligations.

3/ Estimated as total interest obligations minus interest payments by the rest of the public sector.

4/ Includes contributions to IHSS, INJUPEM, and MMPREMA.

$5 /$ Includes change in accounts receivable.

6/ Includes change in accounts payable. 
Table 14. Honduras: Central Government Revenue

\begin{tabular}{|c|c|c|c|c|c|}
\hline & 1993 & 1994 & 1995 & 1996 & $\begin{array}{l}\text { Prel. } \\
1997 \\
\end{array}$ \\
\hline \multicolumn{6}{|c|}{ (In millions of lempiras) } \\
\hline Total revenue & 3,961 & 4,709 & 6,764 & 7,989 & 10,318 \\
\hline Current revenue & 3,844 & 4,589 & 6,737 & 7,968 & 10,305 \\
\hline Tax revenue & 3,609 & 4,384 & 6,476 & 7,503 & 9,666 \\
\hline Direct taxes & 1,167 & 1,145 & 1,799 & 2,034 & 2,508 \\
\hline Income tax & 1,049 & 1,062 & 1,716 & 1,900 & 2,289 \\
\hline Property tax & 34 & 40 & 41 & 68 & 121 \\
\hline Asset revaluation tax & 85 & $\mathbf{0}$ & 2 & 0 & 0 \\
\hline Net assets & 0 & 43 & 40 & 66 & 98 \\
\hline Domestic indirect taxes & 1,384 & 1,845 & 2,552 & 3,114 & 3,956 \\
\hline Sales tax & 697 & 885 & 1,331 & 1,698 & 2,270 \\
\hline Petroleum derivatives & 154 & 270 & 371 & 459 & 406 \\
\hline Alcohol and nonalcohol beverages & 224 & 279 & 418 & 378 & 446 \\
\hline Other & 309 & 411 & 432 & 579 & 834 \\
\hline International trade & 1,057 & 1,295 & 1,751 & 1,804 & 2,154 \\
\hline Imports & 986 & 1,185 & 1,430 & 1,706 & 2,066 \\
\hline Petroleum & 154 & 251 & 324 & 405 & 404 \\
\hline Other & 832 & 934 & 1,106 & 1,301 & 1,662 \\
\hline Exports & 71 & 110 & 321 & 98 & 89 \\
\hline Bananas & 60 & 67 & 91 & 82 & 77 \\
\hline Coffee $1 /$ & 0 & 29 & 215 & 0 & 0 \\
\hline Other & 11 & 14 & 15 & 16 & 12 \\
\hline Petroleum derivatives & 0 & 98 & 373 & 548 & 1,046 \\
\hline Other & 1 & 1 & 2 & 3 & 2 \\
\hline Nontax revenue & 70 & 76 & 107 & 155 & 227 \\
\hline Current transfers & 165 & 130 & 154 & 310 & 412 \\
\hline Capital revenue & 117 & 120 & 27 & 21 & 13 \\
\hline \multicolumn{6}{|c|}{ (In percent of GDP) } \\
\hline Total revenue & 17.5 & 16.3 & 18.0 & 16.7 & 16.9 \\
\hline Current revenue & 16.9 & 15.9 & 18.0 & 16.7 & 16.9 \\
\hline Tax revenue & 15.9 & 15.2 & 17.3 & 15.7 & 15.8 \\
\hline Direct taxes & 5.1 & 4.0 & 4.8 & 4.3 & 4.1 \\
\hline Income tax & 4.6 & 3.7 & 4.6 & 4.0 & 3.7 \\
\hline Property tax & 0.1 & 0.1 & 0.1 & 0.1 & 0.2 \\
\hline Asset revaluation tax & 0.4 & 0.0 & 0.0 & 0.0 & 0.0 \\
\hline Net assets & 0.0 & 0.1 & 0.1 & 0.1 & 0.2 \\
\hline Domestic indirect taxes & 6.1 & 6.4 & 6.8 & 6.5 & 6.5 \\
\hline Sales tax & 3.1 & 3.1 & 3.5 & 3.6 & 3.7 \\
\hline Petroleum derivatives & 0.7 & 0.9 & 1.0 & 1.0 & 0.7 \\
\hline Alcohol and nonalcohol beverages & 1.0 & 1.0 & 1.1 & 0.8 & 0.7 \\
\hline Other & 1.4 & 1.4 & 1.2 & 1.2 & 1.4 \\
\hline International trade & 4.7 & 4.5 & 4.7 & 3.8 & 3.5 \\
\hline Imports & 4.3 & 4.1 & 3.8 & 3.6 & 3.4 \\
\hline Petroleum & 0.7 & 0.9 & 0.9 & 0.8 & 0.7 \\
\hline Other & 3.7 & 3.2 & 2.9 & 2.7 & 2.7 \\
\hline Exports & 0.3 & 0.4 & 0.9 & 0.2 & 0.1 \\
\hline Bananas & 0.3 & 0.2 & 0.2 & 0.2 & 0.1 \\
\hline Coffee & 0.0 & 0.1 & 0.6 & 0.0 & 0.0 \\
\hline Other & 0.0 & 0.0 & 0.0 & 0.0 & 0.0 \\
\hline Petroleum derivatives & 0.0 & 0.3 & 1.0 & 1.1 & 1.7 \\
\hline Other & 0.0 & 0.0 & 0.0 & 0.0 & 0.0 \\
\hline Nontax revenue & 0.3 & 0.3 & 0.3 & 0.3 & 0.4 \\
\hline Current transfers & 0.7 & 0.4 & 0.4 & 0.6 & 0.7 \\
\hline Capital revenue & 0.5 & 0.4 & 0.1 & 0.0 & 0.0 \\
\hline
\end{tabular}

Source: Ministry of Finance. 
Table 15. Honduras: Operations of the Social Security Institute

\begin{tabular}{|c|c|c|c|c|c|}
\hline & 1993 & 1994 & 1995 & 1996 & $\begin{array}{l}\text { Prel. } \\
1997 \\
\end{array}$ \\
\hline \multicolumn{6}{|c|}{ (In millions of lempiras) } \\
\hline Total revenue & 247.0 & 283.2 & 443.3 & 526.5 & 600.6 \\
\hline Current revenue & 247.0 & 283.2 & 443.3 & 526.5 & 600.6 \\
\hline Contributions from & 201.6 & 220.1 & 260.1 & 297.0 & 385.3 \\
\hline Private sector & 138.1 & 163.1 & 195.0 & 222.7 & 288.8 \\
\hline Central government & 21.1 & 21.6 & 20.0 & 22.8 & 29.6 \\
\hline Social security institute & 4.7 & 4.2 & 4.1 & 4.5 & 4.7 \\
\hline Pension funds & 4.6 & 1.8 & 3.0 & 3.4 & 4.4 \\
\hline Local governments & 6.1 & 4.1 & 5.0 & 5.9 & 8.8 \\
\hline Public enterprises & 27.0 & 25.3 & 33.0 & 37.7 & 48.9 \\
\hline Interest earnings & 49.6 & 68.6 & 111.0 & 152.4 & 148.3 \\
\hline Other & 2.2 & 4.8 & 25.0 & 77.1 & 32.8 \\
\hline Change in accounts receivable (increase -) & -6.4 & -10.3 & 47.2 & 0.0 & 34.2 \\
\hline Total expenditure & 193.6 & 211.8 & 229.6 & 268.5 & 333.2 \\
\hline Current expenditure & 176.5 & 196.5 & 225.6 & 228.8 & 298.8 \\
\hline Wages and salaries & 75.9 & 84.9 & 100.3 & 131.4 & 146.7 \\
\hline Goods and services & 63.6 & 63.9 & 65.0 & 67.2 & 70.6 \\
\hline Contribution to social security & 4.7 & 4.2 & 4.1 & 4.5 & 4.7 \\
\hline Current transfers & 32.3 & 50.0 & 56.6 & 25.7 & 78.4 \\
\hline To private sector (benefits) & 32.2 & 45.0 & 56.6 & 22.5 & 71.0 \\
\hline Other & 0.1 & 5.0 & 0.0 & 3.2 & 7.4 \\
\hline Change in accounts payable (increase -) & 0.0 & -65.0 & -0.4 & 0.0 & -1.6 \\
\hline Capital expenditure & 17.1 & 15.3 & 4.0 & 39.7 & 34.4 \\
\hline Fixed capital formation & 17.1 & 15.3 & 4.0 & 39.7 & 2.9 \\
\hline Inventory change & 0.0 & 0.0 & 0.0 & 0.0 & 31.5 \\
\hline Primary current balance & 20.9 & 18.1 & 106.7 & 145.3 & 153.5 \\
\hline Primary balance & 3.8 & 2.8 & 102.7 & 105.6 & 119.1 \\
\hline Current account balance & 70.5 & 86.7 & 217.7 & 297.7 & 301.8 \\
\hline Overall balance & 53.4 & 71.4 & 213.7 & 258.0 & 267.4 \\
\hline \multicolumn{6}{|c|}{ (In percent of GDP) } \\
\hline Current revenue & 1.1 & 1.0 & 1.2 & 1.1 & 1.0 \\
\hline Contributions & 0.9 & 0.8 & 0.7 & 0.6 & 0.6 \\
\hline Interest earnings & 0.2 & 0.2 & 0.3 & 0.3 & 0.2 \\
\hline Other & 0.0 & 0.0 & 0.2 & 0.2 & 0.1 \\
\hline Current expenditure & 0.8 & 0.7 & 0.6 & 0.5 & 0.5 \\
\hline Wages and salaries & 0.3 & 0.3 & 0.3 & 0.3 & 0.2 \\
\hline Current transfers & 0.1 & 0.2 & 0.2 & 0.1 & 0.1 \\
\hline Other & 0.3 & 0.2 & 0.2 & 0.1 & 0.1 \\
\hline Capital expenditure & 0.1 & 0.1 & 0.0 & 0.1 & 0.1 \\
\hline Primary balance & 0.0 & 0.0 & 0.3 & 0.2 & 0.2 \\
\hline Current account balance & 0.3 & 0.3 & 0.6 & 0.6 & 0.5 \\
\hline Overall balance & 0.2 & 0.2 & 0.6 & 0.5 & 0.4 \\
\hline
\end{tabular}

Sources: Central Bank of Honduras; Honduran Institute Social Security; and Fund staff estimates. 
Table 16. Honduras: Operations of INJUPEMP 1/

\begin{tabular}{|c|c|c|c|c|c|}
\hline & 1993 & 1994 & 1995 & 1996 & $\begin{array}{l}\text { Prel. } \\
1997\end{array}$ \\
\hline \multicolumn{6}{|c|}{ (In millions of lempiras) } \\
\hline Total revenue & 234.0 & 279.9 & 337.0 & 421.7 & 527.6 \\
\hline Current revenue & 209.1 & 244.5 & 310.1 & 401.1 & 527.6 \\
\hline Contributions & 110.2 & 143.8 & 177.1 & 204.3 & 311.8 \\
\hline Government employees & 50.9 & 72.3 & 103.1 & 118.9 & 181.5 \\
\hline Central government & 44.1 & 55.1 & 50.6 & 58.4 & 89.1 \\
\hline Local governments & 0.9 & 0.9 & 1.1 & 1.3 & 1.9 \\
\hline Decentralized agencies & 3.3 & 3.5 & 6.8 & 7.8 & 12.0 \\
\hline Public enterprises & 11.0 & 12.0 & 15.5 & 17.9 & 27.3 \\
\hline Interest earnings & 95.6 & 98.3 & 118.0 & 158.0 & 167.8 \\
\hline Other revenue & 9.3 & 2.4 & 15.0 & 4.2 & 46.3 \\
\hline Change in accounts receivable (increase -) & -6.0 & 0.0 & 0.0 & 34.6 & 1.7 \\
\hline Capital revenue & 24.9 & 35.4 & 26.9 & 20.6 & 0.0 \\
\hline Total expenditure & 241.2 & 395.4 & 464.5 & 489.5 & 569.2 \\
\hline Current expenditure & 40.0 & 103.1 & 102.0 & 121.8 & 121.1 \\
\hline Wages and salaries & 7.1 & 9.4 & 9.6 & 12.2 & 15.1 \\
\hline Goods and services & 9.3 & 7.1 & 8.9 & 5.7 & 5.5 \\
\hline Contribution to social security & 0.8 & 0.8 & 1.0 & 1.3 & 1.6 \\
\hline Current transfers & 36.5 & 43.5 & 62.8 & 83.9 & 96.1 \\
\hline To private sector (benefits) & 36.5 & 43.3 & 62.5 & 79.6 & 96.1 \\
\hline Other & 0.0 & 0.2 & 0.3 & 4.3 & 0.0 \\
\hline Change in accounts payable (increase -) & -13.7 & 42.3 & 19.7 & 18.7 & 2.8 \\
\hline Capital expenditure and net lending & 201.2 & 292.3 & 362.5 & 367.7 & 448.1 \\
\hline Fixed capital formation & 152.2 & 228.4 & 295.1 & 226.4 & 144.2 \\
\hline Other & 0.0 & 0.0 & 0.0 & 1.7 & 2.6 \\
\hline Net lending & 49.0 & 63.9 & 67.4 & 139.6 & 301.3 \\
\hline Primary balance & -102.8 & -213.8 & -245.5 & -225.8 & -209.4 \\
\hline Current account balance & 169.1 & 141.4 & 208.1 & 279.3 & 406.5 \\
\hline Overall balance & -7.2 & -115.5 & -127.5 & -67.8 & -41.6 \\
\hline \multicolumn{6}{|c|}{ (In percent of GDP) } \\
\hline Current revenue & 0.9 & 0.8 & 0.8 & 0.8 & 0.9 \\
\hline $\begin{array}{l}\text { Contributions } \\
\text { Interest earnings }\end{array}$ & $\begin{array}{l}0.5 \\
0.4\end{array}$ & $\begin{array}{l}0.5 \\
0.3\end{array}$ & $\begin{array}{l}0.5 \\
0.3\end{array}$ & $\begin{array}{l}0.4 \\
0.3\end{array}$ & $\begin{array}{l}0.5 \\
0.3\end{array}$ \\
\hline Other & 0.0 & 0.0 & 0.0 & 0.1 & 0.1 \\
\hline Current expenditure & 0.2 & 0.4 & 0.3 & 0.3 & 0.2 \\
\hline Current transfers & 0.2 & 0.2 & 0.2 & 0.2 & 0.2 \\
\hline Other & 0.0 & 0.2 & 0.1 & 0.1 & 0.0 \\
\hline Current account balance & 0.7 & 0.5 & 0.6 & 0.6 & 0.7 \\
\hline Capital expenditure and net lending & 0.9 & 1.0 & 1.0 & 0.8 & 0.7 \\
\hline Overall balance & 0.0 & -0.4 & -0.3 & -0.1 & -0.1 \\
\hline
\end{tabular}

Sources: Ministry of Finance; Central Bank of Honduras; INJUPEMP; and Fund staff estimates.

1/ National Institute of Pensions for public employees. 
Table 17. Honduras: Operations of INPREMA I/

\begin{tabular}{|c|c|c|c|c|c|}
\hline & 1993 & 1994 & 1995 & 1996 & $\begin{array}{l}\text { Prel. } \\
1997 \\
\end{array}$ \\
\hline \multicolumn{6}{|c|}{ (In millions of lempiras) } \\
\hline Total revenue & 119.1 & 176.4 & 270.1 & 295.2 & 620.8 \\
\hline Current revenue & 119.1 & 168.5 & 268.5 & 288.3 & 526.8 \\
\hline Contributions from & 120.7 & 148.2 & 186.4 & 182.6 & 282.4 \\
\hline Private sector & 51.0 & 63.8 & 77.4 & 75.8 & 117.3 \\
\hline Central government & 67.4 & 81.4 & 105.0 & 102.9 & 159.1 \\
\hline IMPREMA as employer & 2.3 & 3.0 & 4.0 & 3.9 & 6.1 \\
\hline Interest earnings & 50.1 & 51.0 & 79.5 & 90.0 & 182.9 \\
\hline Other & 4.9 & 20.9 & 2.6 & 13.7 & 33.1 \\
\hline Change in accounts receivable (increase -) & -56.6 & -51.6 & 0.0 & 2.0 & 28.4 \\
\hline Capital revenue & 0.0 & 7.9 & 1.6 & 6.9 & 94.0 \\
\hline 'Total expenditure & 180.2 & 186.6 & 291.2 & 384.3 & 435.8 \\
\hline Current expenditure & 73.9 & 89.8 & 133.6 & 152.6 & 213.8 \\
\hline Wages and salaries & 6.3 & 7.9 & 9.7 & 11.3 & 14.5 \\
\hline Goods and services & 4.4 & 4.9 & 8.9 & 8.1 & 9.4 \\
\hline Contribution to social security & 3.1 & 4.2 & 5.5 & 5.7 & 8.3 \\
\hline Transfers to private sector (benefits) & 62.7 & 76.1 & 110.5 & 135.6 & 180.9 \\
\hline Change in accounts payable (increase -) & -2.6 & -3.4 & -1.0 & -8.1 & 0.7 \\
\hline Capital expenditure and net lending & 106.3 & 96.8 & 157.6 & 231.7 & 222.0 \\
\hline Capital expenditure & 61.5 & 65.3 & 131.6 & 80.5 & 57.8 \\
\hline Fixed capital formation & 46.1 & 65.2 & 131.3 & 78.6 & 51.4 \\
\hline Other & 15.4 & 0.1 & 0.3 & $1.9^{\circ}$ & 6.4 \\
\hline Net lending & 44.8 & 31.5 & 26.0 & 151.2 & 164.2 \\
\hline Primary balance & -111.2 & -61.2 & -100.6 & -179.1 & 2.1 \\
\hline Current account balance & 45.2 & 78.8 & 134.9 & 135.7 & 313.0 \\
\hline Overall balance & -61.1 & -10.2 & -21.1 & -89.1 & 185.0 \\
\hline \multicolumn{6}{|c|}{ (In percent of GDP) } \\
\hline Current account balance & 0.2 & 0.3 & 0.4 & 0.3 & 0.5 \\
\hline Capital expenditure and net lending & 0.5 & 0.3 & 0.4 & 0.5 & 0.4 \\
\hline Overall balance & -0.3 & 0.0 & -0.1 & -0.2 & 0.3 \\
\hline
\end{tabular}

Sources: Central Bank of Honduras; IMPREMA; and Fund staff estimates.

$1 /$ Pension fund for civil service and teachers. 
Table 18. Honduras: Operations of the Local Governments

\begin{tabular}{|c|c|c|c|c|c|}
\hline & 1993 & 1994 & 1995 & 1996 & $\begin{array}{l}\text { Prel. } \\
1997 \\
\end{array}$ \\
\hline \multicolumn{6}{|c|}{ (In millions of lempiras) } \\
\hline Total revenue & 424.4 & 486.9 & 582.2 & 677.6 & 962.5 \\
\hline Current revenue & 306.4 & 375.9 & 446.8 & 520.5 & 655.5 \\
\hline Tax revenue & 196.8 & 212.4 & 206.2 & 282.6 & 345.8 \\
\hline Nontax revenue & 97.5 & 150.0 & 186.1 & 227.7 & 301.9 \\
\hline Current transfers from & 12.1 & 13.5 & 54.5 & 6.8 & 0.0 \\
\hline Central government & 9.1 & 10.3 & 49.5 & 6.8 & 0.0 \\
\hline Public enterprises & 3.0 & 3.2 & 5.0 & 0.0 & 0.0 \\
\hline Interest eamings & 0.0 & 0.0 & 0.0 & 3.4 & 7.8 \\
\hline Capital revenue & 118.0 & 111.0 & 135.4 & 157.1 & $\mathbf{3 0 7 . 0}$ \\
\hline From central government & 114.0 & 107.0 & 131.4 & 147.7 & 262.1 \\
\hline Other & 4.0 & 4.0 & 4.0 & 9.4 & 44.9 \\
\hline Total expenditure & 482.0 & 655.4 & 758.1 & 767.7 & $1,275.4$ \\
\hline Curent expenditures & 274.0 & 352.4 & 384.1 & 425.9 & $\mathbf{5 7 1 . 5}$ \\
\hline Wages and salaries & 168.0 & 162.4 & 194.9 & 245.9 & 275.6 \\
\hline Goods and services & 66.8 & 78.1 & 100.5 & 113.4 & 151.5 \\
\hline Interest & 28.9 & 27.6 & 21.2 & 24.9 & 62.7 \\
\hline Contributions to social security & 7.0 & 5.0 & 6.1 & 7.2 & 10.7 \\
\hline Transfers to private sector & 3.3 & 22.1 & 61.5 & 34.5 & 71.0 \\
\hline Change in accounts payables (increase -) & 0.0 & 57.2 & 0.0 & 0.0 & 0.0 \\
\hline Capital expenditures & 208.0 & 303.0 & 374.0 & 341.8 & 703.9 \\
\hline Fixed capital formation & 208.0 & 303.0 & 374.0 & 341.8 & 700.5 \\
\hline Net lending & 0.0 & 0.0 & 0.0 & 0.0 & 3.4 \\
\hline Primary current account balance & 61.3 & 51.1 & 83.8 & 116.1 & 138.9 \\
\hline Primary balance & -28.7 & -140.9 & -154.8 & -68.6 & -258.0 \\
\hline Current account balance & 32.4 & 23.5 & 62.7 & 94.6 & 84.0 \\
\hline Overall balance & -57.6 & -168.5 & -175.9 & -90.1 & $\mathbf{- 3 1 2 . 9}$ \\
\hline \multicolumn{6}{|c|}{ (In percent of GDP) } \\
\hline Capital expenditure & 0.9 & 1.0 & 1.0 & 0.7 & 1.1 \\
\hline Current account balance & 0.1 & 0.1 & 0.2 & 0.2 & 0.1 \\
\hline Primary balance & -0.1 & -0.5 & -0.4 & -0.1 & -0.4 \\
\hline Overall balance & -0.3 & -0.6 & -0.5 & -0.2 & -0.5 \\
\hline
\end{tabular}

Source: Central government budget. 
Table 19. Honduras: Operations of the Decentralized Agencies 1/

\begin{tabular}{|c|c|c|c|c|c|}
\hline & 1993 & 1994 & 1995 & 1996 & $\begin{array}{l}\text { Prel. } \\
1997 \\
\end{array}$ \\
\hline \multicolumn{6}{|c|}{ (In millions of lempiras) } \\
\hline Total revenue & 452.3 & 654.7 & 645.0 & 652.6 & $1,122.8$ \\
\hline Current revenue & 290.3 & 295.7 & 453.6 & 440.8 & 754.6 \\
\hline Central government transfers & 290.3 & 295.7 & 453.6 & 440.8 & 691.5 \\
\hline Interest earnings & 0.0 & 0.0 & 0.0 & 0.0 & 63.1 \\
\hline Capital revenue & 162.0 & 359.0 & 191.4 & 211.8 & 368.2 \\
\hline Central government transfers & 162.0 & 359.0 & 191.4 & 211.8 & 368.2 \\
\hline Other & 0.0 & 0.0 & 0.0 & 0.0 & 0.0 \\
\hline Total expenditure & 348.2 & 509.3 & $\mathbf{3 7 7 . 5}$ & 483.8 & $1,036.9$ \\
\hline Curent expenditure & 287.6 & 241.2 & 213.9 & 353.8 & 861.0 \\
\hline Wages and salaries & 58.0 & 70.2 & 114.2 & 138.2 & 143.6 \\
\hline Interest & 0.0 & 0.0 & 0.0 & 0.0 & 1.8 \\
\hline Contributions to social security & 3.3 & 3.5 & 6.8 & 7.8 & 12.0 \\
\hline Transfers to private sector & 226.3 & 167.5 & 92.9 & 207.8 & 703.6 \\
\hline Capital expenditure & 60.6 & 268.1 & 163.6 & 130.0 & 175.9 \\
\hline Fixed capital formation & 60.6 & 268.1 & 163.6 & 130.0 & 175.9 \\
\hline Primary balance & 104.1 & 145.4 & 267.5 & 168.8 & 24.6 \\
\hline Current account balance & 2.7 & 54.5 & 239.7 & 87.0 & -106.4 \\
\hline Overall balance & 104.1 & 145.4 & 267.5 & 168.8 & 85.9 \\
\hline \multicolumn{6}{|c|}{ (In percent of GDP) } \\
\hline Capital expenditure & 0.3 & 0.9 & 0.4 & 0.3 & 0.3 \\
\hline Current accountbalance & 0.0 & 0.2 & 0.6 & 0.2 & -0.2 \\
\hline Primary balance & 0.5 & 0.5 & 0.7 & 0.4 & 0.0 \\
\hline Overall balance & 0.5 & 0.5 & 0.7 & 0.4 & 0.1 \\
\hline
\end{tabular}

Source: Central government budget.

1/ Includes SID, INA, INFOP, IHADFA, IHDECOOP, JNBS, UNAH, UPN, PANI, EDUCREDITO, JOURNALISTS CORP, SPORTS FED. Excluding FHIS. 
Table 20. Honduras: Operations of National Enterprise of Electricity Energy, ENEE

\begin{tabular}{|c|c|c|c|c|c|}
\hline & 1993 & 1994 & 1995 & 1996 & $\begin{array}{l}\text { Prel. } \\
1997 \\
\end{array}$ \\
\hline \multicolumn{6}{|c|}{ (In millions of lempiras) } \\
\hline Operating revenue & 865.7 & $1,032.3$ & $1,435.6$ & $2,104.5$ & $2,567.7$ \\
\hline Sales of electricity $1 /$ & 894.0 & 986.7 & $1,542.6$ & $2,156.9$ & $2,525.0$ \\
\hline Interest earnings & 0.0 & 0.0 & 0.0 & 13.4 & 32.4 \\
\hline Other goods and services & 25.8 & 81.8 & 30.4 & 103.7 & 132.9 \\
\hline Change in accounts receivable (increase -) & -54.1 & -36.2 & -137.4 & -169.5 & -122.6 \\
\hline Operating expenditure & 334.4 & 763.3 & $1,544.2$ & $2,029.7$ & $2,035.6$ \\
\hline Wages and salaries $2 /$ & 81.4 & 101.8 & 99.1 & 144.8 & 160.7 \\
\hline Severance payments & 0.0 & 0.0 & 13.1 & 12.5 & 7.9 \\
\hline Goods and services & 156.6 & 343.2 & $1,033.6$ & $1,337.2$ & $1,488.1$ \\
\hline Fuels & 99.9 & 87.1 & 270.5 & 56.9 & 59.4 \\
\hline Others including maintenance & 51.7 & 60.6 & 65.8 & 76.8 & 8.3 \\
\hline Purchase of energy & 5.0 & 195.5 & 697.3 & $1,203.5$ & $1,420.4$ \\
\hline Interest & 220.6 & 311.4 & 398.4 & 466.0 & 301.9 \\
\hline External & 163.9 & 187.9 & 364.8 & 412.1 & 286.4 \\
\hline Domestic & 56.7 & 123.5 & 33.6 & 53.9 & 15.5 \\
\hline Other & 8.2 & 6.9 & 0.0 & 42.4 & 161.8 \\
\hline Change in accounts payable (increase -) & -132.4 & 0.0 & 0.0 & 26.8 & -84.8 \\
\hline Operating balance & 531.3 & 269.0 & -108.6 & 74.8 & 532.1 \\
\hline Net transfer payments & 28.1 & 2.3 & 4.0 & -224.0 & -274.5 \\
\hline Taxes and transfer payments & 28.1 & 5.7 & 4.0 & 7.5 & 39.3 \\
\hline To central government & 25.9 & 3.4 & 0.0 & 0.1 & 0.0 \\
\hline To rest of general government & 2.2 & 2.3 & 0.0 & 0.0 & 0.0 \\
\hline To private sector & 0.0 & 0.0 & 4.0 & 7.4 & 39.3 \\
\hline Transfer receipts & 0.0 & 3.4 & 0.0 & 231.5 & 313.8 \\
\hline From central government & 0.0 & 3.4 & 0.0 & 231.5 & 313.8 \\
\hline Current account balance & 503.2 & 266.6 & -112.6 & 298.8 & 806.6 \\
\hline Net capital revenue & 66.6 & 0.0 & 36.4 & 10.0 & 20.0 \\
\hline Capital tranfers receipts & 66.6 & 0.0 & 36.4 & 10.0 & 20.0 \\
\hline From central government & 66.6 & 0.0 & 36.4 & 10.0 & 20.0 \\
\hline Capital expenditure & 424.8 & 408.2 & 170.4 & 305.9 & 382.3 \\
\hline Primary balance & 365.6 & 169.8 & 151.8 & 455.5 & 713.8 \\
\hline Overall balance & 145.0 & -141.6 & -246.6 & 2.9 & 444.3 \\
\hline Financing & -145.0 & 141.6 & 246.6 & -2.9 & -444.3 \\
\hline Foreign (net) & -216.1 & -308.4 & -90.3 & -274.8 & -214.8 \\
\hline Drawings & 310.9 & 232.1 & 246.7 & 7.7 & 15.9 \\
\hline Amortization payments & 527.0 & 540.5 & 281.3 & 282.5 & 230.7 \\
\hline Payment of arrears & 0.0 & 0.0 & 55.7 & 0.0 & 0.0 \\
\hline Domestic & 71.1 & 450.0 & 336.9 & 271.9 & -229.5 \\
\hline Central bank & 59.3 & 43.1 & -34.4 & 27.1 & -16.1 \\
\hline Rest of banking system & -0.2 & -12.4 & -3.1 & 7.4 & -69.4 \\
\hline Government emergency loan & 0.0 & 468.0 & 500.4 & 203.0 & 105.2 \\
\hline \multicolumn{6}{|l|}{ From government with } \\
\hline foreign resources & 0.0 & 0.0 & -46.2 & 53.1 & -183.7 \\
\hline \multicolumn{6}{|l|}{ Investment in securities and } \\
\hline foreign account & 0.0 & 0.0 & 16.3 & 16.3 & -67.0 \\
\hline Other & 12.0 & 37.5 & -96.1 & -35.0 & 1.5 \\
\hline
\end{tabular}


Table 20. Honduras: Operations of National Enterprise of Electricity Energy, ENEE

\begin{tabular}{|c|c|c|c|c|c|}
\hline & 1993 & 1994 & 1995 & 1996 & $\begin{array}{l}\text { Prel. } \\
1997 \\
\end{array}$ \\
\hline \multicolumn{6}{|c|}{ (In percent of GDP) } \\
\hline Operating revenue & 3.8 & 3.6 & 3.8 & 4.4 & 4.2 \\
\hline Operating expenditure & 1.5 & 2.6 & 4.1 & 4.2 & 3.3 \\
\hline Net current transfer payments & 0.1 & 0.0 & 0.0 & -0.5 & -0.4 \\
\hline Net capital revenue & 0.3 & 0.0 & 0.1 & 0.0 & 0.0 \\
\hline Capital expenditure & 1.9 & 1.4 & 0.5 & 0.6 & 0.6 \\
\hline Operating balance & 2.3 & 0.9 & -0.3 & 0.2 & 0.9 \\
\hline Current account balance & 2.2 & 0.9 & -0.3 & 0.6 & 1.3 \\
\hline Primary balance & 1.6 & 0.6 & 0.4 & 1.0 & 1.2 \\
\hline Overall balance & 0.6 & -0.5 & -0.7 & 0.0 & 0.7 \\
\hline External financing & -1.0 & -1.1 & -0.2 & -0.6 & -0.3 \\
\hline Domestic financing & 0.3 & 1.6 & 0.9 & 0.6 & -0.4 \\
\hline \multicolumn{6}{|l|}{ Memorandum items: } \\
\hline Tariff in lempiras per $\mathrm{KWH}$, average & 0.49 & 0.57 & 0.80 & 0.99 & 1.14 \\
\hline Tariff in U.S. cents per KWH, average & 7.53 & 6.79 & 7.82 & 7.76 & 8.70 \\
\hline \multicolumn{6}{|l|}{ Output sold in $\mathrm{GW} / \mathrm{H}$} \\
\hline (in millions of lempiras) & 1,820 & 1,730 & 1,586 & 2,193 & 2,828 \\
\hline
\end{tabular}

Sources: Ministry of Finance; ENEE; Central Bank; and Fund staff estimates.

$1 /$ On accrual basis; cash amounts obtained by deducting changes in accounts receivable.

$2 /$ Includes employers contributions to the social security system. 
Table 21. Honduras: Operations of the National Telecommunications Enterprise, HONDUTEL

\begin{tabular}{|c|c|c|c|c|c|}
\hline & 1993 & 1994 & 1995 & 1996 & $\begin{array}{l}\text { Prel. } \\
1997\end{array}$ \\
\hline \multicolumn{6}{|c|}{ (In millions of lempiras) } \\
\hline Operating revenue & 637.4 & 780.1 & $1,074.7$ & $1,688.8$ & $\mathbf{1 , 8 7 4 . 2}$ \\
\hline Sales of goods and services $1 /$ & 624.3 & 856.8 & $1,235.4$ & $1,645.1$ & $1,884.5$ \\
\hline Interest earnings & 0.0 & 5.3 & 7.5 & 50.8 & 51.9 \\
\hline Other & 22.7 & 12.2 & 75.9 & 136.8 & 32.3 \\
\hline Change in accounts receivable (increase -) & -9.6 & -94.2 & -244.1 & -143.9 & -94.5 \\
\hline Operating expenditure & 173.5 & 315.1 & 451.6 & 677.1 & 565.6 \\
\hline Wages and salaries 2/ & 114.3 & 141.5 & 211.9 & 260.1 & 324.0 \\
\hline Severance payments & 0.0 & 0.0 & 29.4 & 29.5 & 7.4 \\
\hline Goods and services & 40.7 & 53.6 & 66.9 & 171.3 & 124.4 \\
\hline Interest & 57.0 & 143.5 & 107.6 & 123.2 & 109.8 \\
\hline External & $\$ 7.0$ & 111.1 & 94.0 & 111.6 & 103.3 \\
\hline Domestic & 0.0 & 32.4 & 13.6 & 11.6 & 6.5 \\
\hline Other & 8.7 & 16.5 & 8.8 & 0.0 & 0.0 \\
\hline Change in accounts payable (increase -) & -47.2 & -40.0 & 27.0 & 93.0 & 0.0 \\
\hline Operating balance & 463.9 & 465.0 & 623.1 & $1,011.7$ & $1,308.6$ \\
\hline Net transfer payments & 156.8 & 147.2 & 138.4 & 202.7 & 212.3 \\
\hline Taxes and transfer payments & 156.8 & 147.2 & 138.4 & 202.7 & 212.3 \\
\hline To central government & 135.3 & 129.4 & 123.2 & 184.4 & 189.6 \\
\hline To rest of general government & 11.5 & 0.0 & 0.0 & 0.0 & 0.0 \\
\hline To private sector & 8.9 & 15.6 & 9.5 & 0.0 & 6.6 \\
\hline To abroad & 1.1 & 2.2 & 5.7 & 18.3 & 15.9 \\
\hline Current account balance & 307.1 & 317.8 & 484.7 & 809.0 & $1,096.3$ \\
\hline Net capital revenue & 0.0 & 16.9 & 0.0 & $\mathbf{5 8 . 0}$ & 0.0 \\
\hline Capital revenue & 0.0 & 16.9 & 0.0 & 58.0 & 0.0 \\
\hline Capital expenditure & 179.7 & 592.2 & 681.7 & $1,093.1$ & 711.9 \\
\hline Fixed investment & 91.8 & 509.9 & 701.6 & $1,078.0$ & 724.9 \\
\hline Inventory changes & 45.2 & 39.8 & $-21,6$ & 14.5 & -13.5 \\
\hline Other & 42.7 & 42.5 & 1.7 & 0.6 & 0.5 \\
\hline Primary balance & 184.4 & -119.3 & -96.9 & -153.7 & 442.3 \\
\hline Overall balance & 127.4 & -257.5 & -197.0 & -226.1 & 384.4 \\
\hline Total financing & -127.4 & 257.5 & 197.0 & 226.1 & -384.4 \\
\hline Foreígn & -40.6 & 161.6 & -39.1 & -486.4 & -357.9 \\
\hline Drawings & 860.7 & 440.0 & 3.2 & 4.3 & 30.8 \\
\hline Amortization & 102.7 & 80.0 & 42.3 & 490.7 & 388.7 \\
\hline Investment trust amortization & 798.6 & 198.4 & 0.0 & 0.0 & 0.0 \\
\hline Domestic & -86.8 & 95.9 & 236.1 & 712.5 & -26.5 \\
\hline Central bank & -19.9 & 53.2 & 64.0 & -130.3 & 5.3 \\
\hline Rest of banking system & 32.0 & 55.9 & 11.0 & -9.5 & -70.9 \\
\hline Government with foreign resources & 0.0 & 0.0 & -144.9 & 0.0 & 0.0 \\
\hline \multicolumn{6}{|l|}{ Investment in securities and } \\
\hline foreign account & 0.0 & 0.0 & 0.0 & 554.9 & $-22,3$ \\
\hline Other & .98 .9 & -15.2 & 306.0 & 297.4 & 61.4 \\
\hline
\end{tabular}


Table 21. Honduras: Operations of the National Telecommunications Enterprise, HONDUTEL

\begin{tabular}{|c|c|c|c|c|c|}
\hline & 1993 & 1994 & 1995 & 1996 & $\begin{array}{r}\text { Prel. } \\
1997 \\
\end{array}$ \\
\hline \multicolumn{6}{|c|}{ (In percent of GDP) } \\
\hline Operating revenue & 2.8 & 2.7 & 2.9 & 3.5 & 3.1 \\
\hline Operating expenditure & 0.8 & 1.1 & 1.2 & 1.4 & 0.9 \\
\hline Net current transfers payments & 0.7 & 0.5 & 0.4 & 0.4 & 0.3 \\
\hline Net capital revenue & 0.0 & 0.1 & 0.0 & 0.1 & 0.0 \\
\hline Capital expenditure & 0.8 & 2.1 & 1.8 & 2.3 & 1.2 \\
\hline Operating balance & 2.0 & 1.6 & 1.7 & 2.1 & 2.1 \\
\hline Current account balance & 1.4 & 1.1 & 1.3 & 1.7 & 1.8 \\
\hline Primary balance & 0.8 & -0.4 & -0.3 & -0.3 & 0.7 \\
\hline Overall balance & 0.6 & .0 .9 & -0.5 & -0.5 & 0.6 \\
\hline External financing & -0.2 & 0.6 & -0.1 & -1.0 & -0.6 \\
\hline Domestic financing & -0.4 & 0.3 & 0.6 & 1.5 & 0.0 \\
\hline
\end{tabular}

Sources: Ministry of Finance; HONDUTEL; Central Bank of Honduras; and Fund staff estimates.

1/ On accrual basis; cash amounts obtained by deducting changes in accounts receivable.

$2 /$ Includes employers contributions to the social security system. 
Table 22. Honduras: Operations of the National Autonomous Water and Sewerage Service, SANAA

\begin{tabular}{|c|c|c|c|c|c|}
\hline & 1993 & 1994 & 1995 & 1996 & $\begin{array}{l}\text { Prel. } \\
1997 \\
\end{array}$ \\
\hline \multicolumn{6}{|c|}{ (In millions of lempiras) } \\
\hline Operating revenue & 30.5 & 59.9 & 92.5 & 110.9 & 158.7 \\
\hline Sales of goods and services $1 /$ & 39.5 & 46.9 & 74.6 & 104.1 & 117.3 \\
\hline Interest earnings & 0.0 & 0.0 & 0.0 & 0.0 & 4.2 \\
\hline Other & 0.1 & 12.1 & 17.9 & 26.3 & 27.9 \\
\hline Change in accounts receivable (increase -) & -9.1 & 0.9 & 0.0 & -19.5 & 9.3 \\
\hline Operating expenditure & 2.8 & 50.5 & 68.5 & 107.9 & 112.5 \\
\hline Wages and salaries $2 /$ & 22.5 & 28.2 & 34.8 & 42.7 & 58.0 \\
\hline Severance payments & 0.0 & 0.0 & 3.2 & 5.7 & 5.4 \\
\hline Goods and services & 28.6 & 21.0 & 29.7 & 33.5 & 59.9 \\
\hline Interest & 0.9 & 0.8 & 0.8 & 0.9 & 0.0 \\
\hline External & 0.0 & 0.0 & 0.0 & 0.0 & 0.0 \\
\hline Domestic & 0.9 & 0.8 & 0.8 & 0.9 & 0.0 \\
\hline Other & 0.5 & 0.5 & 0.0 & 1.8 & 0.0 \\
\hline Change in accounts payable (increase -) & -49.7 & 0.0 & 0.0 & 23.3 & -10.8 \\
\hline Operating balance & 27.7 & 9.4 & 24.0 & 3.0 & 46.2 \\
\hline Net transfer payments & 6.5 & 10.6 & 0.0 & 0.0 & 0.1 \\
\hline Taxes and transfer payments & 6.5 & 10.6 & 0.0 & 0.0 & 0.1 \\
\hline To central government & 5.2 & 5.1 & 0.0 & 0.0 & 0.0 \\
\hline To rest of general government & 1.3 & 1.3 & 0.0 & 0.0 & 0.0 \\
\hline To private sector & 0.0 & 4.1 & 0.0 & 0.0 & 0.1 \\
\hline Current account balance & 21.2 & -1.2 & 24.0 & 3.0 & 46.1 \\
\hline Net capital revenue & 221.5 & 123.7 & 311.7 & 151.3 & 95.7 \\
\hline Capital revenue & 0.0 & 7.3 & 0.0 & 0.0 & 0.0 \\
\hline Capital tranfers receipts & 221.5 & 116.4 & 311.7 & 151.3 & 95.7 \\
\hline From central government & 221.5 & 116.4 & 216.8 & 151.3 & 95.7 \\
\hline From other & 0.0 & 0.0 & 94.9 & 0.0 & 0.0 \\
\hline Capital expenditure & 228.4 & 124.1 & 311.7 & 161.0 & 137.7 \\
\hline Fixed investment & 173.3 & 123.7 & 291.4 & 165.4 & 127.6 \\
\hline Inventory changes & 55.1 & 0.4 & 20.3 & -4.4 & 10.1 \\
\hline Primary balance & 15.2 & -0.8 & 24.8 & -5.8 & -0.1 \\
\hline Overall balance & 14.3 & -1.6 & 24.0 & -6.7 & 4.1 \\
\hline Financing & -14.3 & 1.6 & -24.0 & 6.7 & -4.1 \\
\hline Foreign & -0.3 & -3.2 & 0.0 & 0.0 & 0.0 \\
\hline Drawings & 2.1 & 0.0 & 0.0 & 0.0 & 0.0 \\
\hline Amortization payments & 2.4 & 3.2 & 0.0 & 0.0 & 0.0 \\
\hline Domestic & -14.0 & 4.8 & -24.0 & 6.7 & -4.1 \\
\hline Central bank & 0.0 & -4.8 & 0.0 & -0.4 & -12.9 \\
\hline Rest of banking system & 0.1 & 1.4 & -0.1 & 0.0 & 0.0 \\
\hline Other & -14.1 & 8.2 & -23.9 & 7.1 & 8.8 \\
\hline
\end{tabular}


Table 22. Honduras: Operations of the National Autonomous Water and Sewerage Service, SANAA

\begin{tabular}{lllll}
1993 & 1994 & 1995 & 1996 & Prel. \\
\hline
\end{tabular}

(In percent of GDP)

\begin{tabular}{llllll} 
Operating revenue & 0.1 & 0.2 & 0.2 & 0.2 & 0.3 \\
Operating expenditure & 0.0 & 0.2 & 0.2 & 0.2 & 0.2 \\
Net current transfer payments & 0.0 & 0.0 & 0.0 & 0.0 & 0.0 \\
Net capital revenue & 1.0 & 0.4 & 0.8 & 0.3 & 0.2 \\
Capital expenditure & 1.0 & 0.4 & 0.8 & 0.3 & 0.2 \\
Operating balance & & & & & 0.0 \\
Current account balance & 0.1 & 0.0 & 0.1 & 0.1 \\
Primary balance & 0.1 & 0.0 & 0.1 & 0.0 & 0.1 \\
& 0.1 & 0.0 & 0.1 & 0.0 & 0.0 \\
Overall balance & 0.1 & 0.0 & 0.1 & 0.0 & 0.0 \\
\hline
\end{tabular}

Sources: Ministry of Finance; SANAA; Central Bank; and Fund staff estimates.

1/ On accrual basis; cash amounts obtained by deducting changes in accounts receivable.

$2 /$ Includes employers contributions to the social security system. 
Table 23. Honduras: Operations of the National Ports Enterprise, ENP

\begin{tabular}{|c|c|c|c|c|c|}
\hline & 1993 & 1994 & 1995 & 1996 & $\begin{array}{r}\text { Prel. } \\
1997 \\
\end{array}$ \\
\hline \multicolumn{6}{|c|}{ (In millions of lempiras) } \\
\hline Operating revenue & 165.8 & 247.3 & 291.9 & 394.9 & 479.7 \\
\hline Sales of goods and services $1 /$ & 145.2 & 235.5 & 291.8 & 360.7 & 459.1 \\
\hline Interest earnings & 0.0 & 0.0 & 0.0 & 17.0 & 31.9 \\
\hline Other & 16.0 & 14.1 & 14.7 & 18.1 & 6.7 \\
\hline Change in accounts receivable (increase -) & 4.6 & -2.3 & -14.6 & -0.9 & -18.0 \\
\hline Operating expenditure & 88.3 & $\mathbf{8 1 . 8}$ & 114.9 & 168.9 & 196.3 \\
\hline Wages and salaries & 44.2 & 56.3 & 56.2 & 68.0 & 77.7 \\
\hline Severance payments $2 /$ & 0.0 & 0.0 & 7.9 & 5.7 & 10.0 \\
\hline Goods and services & 18.7 & 23.9 & 26.4 & 33.2 & 42.3 \\
\hline Interest & 5.9 & 10.6 & 30.0 & 27.0 & 28.7 \\
\hline External & 4.0 & 10.2 & 29.2 & 18.8 & 28.0 \\
\hline Domestic & 1.9 & 0.4 & 0.8 & 8.2 & 0.7 \\
\hline Other & 0.0 & 0.3 & 7.6 & 7.1 & 0.0 \\
\hline Change in accounts payable (increase -) & 19.5 & -9.3 & -13.2 & 27.9 & 37.6 \\
\hline Operating balance & 77.5 & 165.5 & 177.0 & 226.0 & 283.4 \\
\hline Net transfer payments & 32.6 & 35.6 & $\mathbf{3 5 . 5}$ & 42.8 & 105.6 \\
\hline Taxes and transfer payments & 32.6 & 35.6 & 35.5 & 42.8 & 105.6 \\
\hline To central government & 27.0 & 25.6 & 23.0 & 25.7 & 80.7 \\
\hline To rest of general government & 0.7 & 8.7 & 11.3 & 13.4 & 17.1 \\
\hline To private sector & 4.8 & 0.8 & 0.5 & 2.4 & 6.4 \\
\hline To abroad & 0.1 & 0.5 & 0.7 & 1.3 & 1.4 \\
\hline Current account balance & 44.9 & 129.9 & 141.5 & 183.2 & 177.8 \\
\hline Net capital revenue & -3.4 & 50.7 & 0.0 & 12.3 & 0.0 \\
\hline Capital revenue & 2.2 & 50.7 & 0.0 & 12.3 & 0.0 \\
\hline Capital transfers payments & 5.6 & 0.0 & 0.0 & 0.0 & 0.0 \\
\hline To rest of general government & 5.6 & 0.0 & 0.0 & 0.0 & 0.0 \\
\hline Capital expenditure & 135.2 & 119.5 & 123.4 & 51.1 & 47.8 \\
\hline Fixed investment & 132.1 & 114.4 & 122.5 & 43.8 & 44.5 \\
\hline Inventory changes & 2.9 & 2.4 & 0.6 & 7.3 & 1.7 \\
\hline Other & 0.2 & 2.7 & 0.1 & 0.0 & 0.0 \\
\hline Net lending & 0.0 & 0.0 & 0.2 & 0.0 & 1.6 \\
\hline Primary balance & -87.8 & 71.7 & 48.1 & 154.4 & 126.8 \\
\hline Overall balance & -93.7 & 61.1 & 18.1 & 144.4 & 130.0 \\
\hline Financing & 93.7 & -61.1 & -18.1 & -144.4 & -130.0 \\
\hline Foreign & 51.6 & 39.0 & 55.1 & -115.7 & -32.9 \\
\hline Drawings & 63.3 & 61.8 & 67.0 & 0.0 & 0.0 \\
\hline Amortization & 11.7 & 22.8 & 11.9 & 115.7 & 32.9 \\
\hline Domestic & 42.1 & -100.1 & -73.2 & -28.7 & -97.1 \\
\hline Central bank & -7.8 & -17.1 & -73.9 & -7.2 & 0.7 \\
\hline Rest of banking system & -27.9 & 1.0 & -71.3 & 3.3 & -20.6 \\
\hline Investment in securities & -19.8 & 1.0 & -2.2 & -33.6 & -90.1 \\
\hline Other & 97.6 & -85.0 & 74.2 & 8.8 & 12.9 \\
\hline
\end{tabular}


Table 23. Honduras: Operations of the National Ports Enterprise, ENP

\begin{tabular}{|c|c|c|c|c|c|}
\hline & 1993 & 1994 & 1995 & 1996 & $\begin{array}{l}\text { Prel. } \\
1997 \\
\end{array}$ \\
\hline \multicolumn{6}{|c|}{ (In percent of GDP) } \\
\hline Operating revenue & 0.7 & 0.9 & 0.8 & 0.8 & 0.8 \\
\hline Operating expenditure & 0.4 & 0.3 & 0.3 & 0.4 & 0.3 \\
\hline Net transfer payments & 0.1 & 0.1 & 0.1 & 0.1 & 0.2 \\
\hline Net capital revenue & 0.0 & 0.2 & 0.0 & 0.0 & 0.0 \\
\hline Capital expenditure & 0.6 & 0.4 & 0.3 & 0.1 & 0.1 \\
\hline Operating balance & 0.3 & 0.6 & 0.5 & 0.5 & 0.5 \\
\hline Current account balance & 0.2 & 0.5 & 0.4 & 0.4 & 0.3 \\
\hline Primary balance & -0.4 & 0.2 & 0.1 & 0.3 & 0.2 \\
\hline Overall balance & -0.4 & 0.2 & 0.0 & 0.3 & 0.2 \\
\hline External financing & 0.2 & 0.1 & 0.1 & -0.2 & -0.1 \\
\hline Domestic financing & 0.2 & -0.3 & -0.2 & -0.1 & -0.2 \\
\hline
\end{tabular}

Sources: Ministry of Finance; Central Bank; and Fund staff estimates.

1/ On accrual basis; cash amounts obtained by deducting changes in accounts receivable.

$2 /$ Includes employers contributions to the social security system. 
Table 24. Honduras: Detailed Accounts of the Financial System

(In millions of lempiras)

\begin{tabular}{|c|c|c|c|c|c|c|}
\hline & \multicolumn{3}{|c|}{$1.10 .34=U S \$ 1$} & \multicolumn{3}{|c|}{$L 130=U S S 1$} \\
\hline & 1993 & 1994 & 1995 & 1995 & 1996 & 1997 \\
\hline \multicolumn{7}{|c|}{ I. Central Bank } \\
\hline Net international reserves & -284.8 & -27.0 & $1,170.4$ & $1,471.0$ & $2,743.1$ & $6,388.9$ \\
\hline Foreign assets & $1,359.8$ & $2,123.5$ & $3,058.5$ & $3,844.2$ & $3,677.9$ & $7,680.2$ \\
\hline Net IMF position & $-1,266.3$ & $-1,099.9$ & $-1,079.7$ & $-1,357.0$ & -759.2 & -601.7 \\
\hline Other short-term foreign liabilities & -378.3 & $-1,050.6$ & -808.4 & $-1,016.2$ & -175.6 & -689.6 \\
\hline Domestic assets & $5,647.6$ & $6,937.1$ & $6,439.2$ & $6,938.8$ & $6,351.8$ & $1,930.8$ \\
\hline Credit to public sector & 413.9 & 336.6 & -316.9 & -459.2 & -693.4 & $-1,610.5$ \\
\hline Central government & 481.6 & 424.2 & -68.0 & -167.5 & -431.5 & $-1,002.0$ \\
\hline Credit & $1,974.2$ & $1,478.4$ & $1,250,8$ & $1,250.8$ & $1,138.2$ & $1,411.3$ \\
\hline Deposits & $-1,492.6$ & $-1,054.2$ & $-1,318,8$ & $-1,418.3$ & $-1,569.7$ & $-2,413.3$ \\
\hline Rest of the public sector & -67.7 & .87 .6 & -248.9 & -291.7 & -261.9 & -608.5 \\
\hline Credit & 164.3 & 137.0 & 140.0 & 140.0 & 173.0 & 99.2 \\
\hline Deposits & -232.0 & -224.6 & -388.9 & -431.7 & -434.9 & -707.7 \\
\hline Government trust fund & -104.8 & -130.9 & -174.3 & -174.3 & -200.6 & 0.0 \\
\hline FHIS & -29.8 & -23.7 & -8.7 & -8.7 & -22.0 & -7.5 \\
\hline Official capital & -925.9 & $-1,160.6$ & $-1,468.5$ & $-1,468.5$ & $-1,577.1$ & $-1,286.4$ \\
\hline Credit to the private sector & 59.2 & 58.1 & 63.7 & 63.7 & 57.7 & 5.0 \\
\hline Arrears deposits & -20.0 & 0.0 & 0.0 & 0.0 & 0.0 & 0.0 \\
\hline Credit to banks, net & $1,017.4$ & 894.7 & 429.8 & 429.8 & -137.3 & $-3,820.8$ \\
\hline Claims on banks & $1,214.6$ & $1,250.0$ & $1,187.4$ & $1,187.4$ & $1,274.7$ & 288.5 \\
\hline Development banks & 352.6 & 342.8 & 331.3 & 331.3 & 311.9 & 151.1 \\
\hline Commercial banks & 664.6 & 678.2 & 615.7 & 615.7 & 720.4 & 135.7 \\
\hline Specialized saving institutions & 197.4 & 229.0 & 240.4 & 240.4 & 242.4 & 1.7 \\
\hline Liabilities to banks & -197.2 & -355.3 & -757.6 & -757.6 & $-1,412.0$ & $-4,109.3$ \\
\hline Net unclassified assets & $5,498.1$ & $7,243.0$ & $8,224.2$ & $8,945.8$ & $9,280.1$ & $8,991.7$ \\
\hline Exchange \}osses & $5,818.3$ & $6,061.7$ & $6,006.9$ & $6,006.9$ & $7,220.7$ & $5,923.8$ \\
\hline Other $1 /$ & -320.2 & $1,181.3$ & $2,217.3$ & $2,938.9$ & $2,059.4$ & $3,067.9$ \\
\hline Allocation of SDRs & -280.5 & -280.1 & -310.1 & -389.8 & -355.6 & -340.7 \\
\hline Medium- and long-term foreign liabilities & $3,671.5$ & $4,498.4$ & $4,825.4$ & $5,625.6$ & $5,540.2$ & $3,672.7$ \\
\hline Private sector deposits & 48.6 & 98.6 & 274.2 & 274.2 & 377.0 & 568.0 \\
\hline Money & 28.7 & 74.3 & 191.4 & 191.4 & 142.6 & 264.2 \\
\hline Sight deposits & 20.0 & 43.7 & 19.8 & 19.8 & 18.4 & 22.5 \\
\hline Time and savings deposits & 8.7 & 30.6 & 171.6 & 171.6 & 124.2 & 241.7 \\
\hline Bonds & 19.9 & 24.3 & 32.2 & 32.2 & $\mathbf{3 7 . 3}$ & 0.0 \\
\hline CAMs & 0.0 & 0.0 & 50.6 & 50.6 & 197.1 & 303.8 \\
\hline Currency issue & $1,642.7$ & $2,313.1$ & $2,510.0$ & $2, \mathbf{5 1 0 . 0}$ & $3,177.7$ & $4,079.0$ \\
\hline Cash in vault & 217.6 & 347.2 & 432.3 & 432.3 & 582.8 & 804.1 \\
\hline Currency in circulation & $1,425.1$ & $1,965.9$ & $2,077.7$ & $2,077.7$ & $2,594.9$ & $3,274.9$ \\
\hline
\end{tabular}


Table 24. Honduras: Detailed Accounts of the Financial System

(In millions of lempiras)

\begin{tabular}{|c|c|c|c|c|c|c|}
\hline & \multicolumn{3}{|c|}{$L 10.34=U S \$ 1$} & \multicolumn{3}{|c|}{$1.13 .0=U S \$ 1$} \\
\hline & 1993 & 1994 & 1995 & 1995 & 1996 & 1997 \\
\hline \multicolumn{7}{|c|}{ II. Commercial Banks } \\
\hline Net international reserves & 661.9 & 571.8 & 803.2 & $1,009.5$ & $1,312.1$ & $2,185.4$ \\
\hline Foreign assets & 777.7 & 853.2 & $1,262.3$ & $1,586.5$ & $2,079,0$ & $3,470.3$ \\
\hline Short-term foreign liabilities & -115.8 & -281.4 & -459.1 & -577.0 & -766.9 & $-1,284.9$ \\
\hline Claims on central bank & 451.8 & 694.5 & $1,145,4$ & $1,145.4$ & $1,993.5$ & $4,459.4$ \\
\hline Cash in vaults & 195.1 & 318.3 & 398.9 & 398.9 & 547.4 & 763.9 \\
\hline Deposits & 227.7 & 349.3 & 558.6 & 558.6 & 578.0 & $1,378.7$ \\
\hline FOVI bonds $2 /$ & 29.0 & 26.9 & 27.8 & 27.8 & 27.0 & 0.0 \\
\hline CAMs 3/ & 0.0 & 0.0 & 160.1 & 160.1 & 841.1 & $2,316.8$ \\
\hline Domestic assets & $6,608.3$ & $8,938.1$ & $10,601.5$ & $10,997.3$ & $15,047.7$ & $19,144.5$ \\
\hline Credit to public sector (net) & 464.3 & 798.6 & 651.1 & 641.0 & 193.5 & -728.6 \\
\hline Central govermment & 937.1 & $1,253.4$ & $1,155.9$ & $1,155.9$ & 816.3 & 275.0 \\
\hline Credit & 937.8 & $1,260.1$ & $1,177.6$ & $1,177.6$ & 840.6 & 275.0 \\
\hline Deposits & .0 .7 & -6.7 & -21.7 & -21.7 & -24.3 & 0.0 \\
\hline Rest of public sector & -472.8 & -454.8 & -504.8 & -514.9 & -622.8 & $-1,003.6$ \\
\hline Credit & 2.4 & 1.2 & 9.9 & 9.9 & 15.2 & 53.8 \\
\hline Deposits & -475.2 & -456.0 & -514.7 & -524.8 & -638.0 & $-1,057.4$ \\
\hline Credit to rest of banking system & 0.0 & 0.0 & 0.0 & 0.0 & 0.0 & 0.0 \\
\hline \multicolumn{7}{|l|}{ Credit to nonbank private financial } \\
\hline intermediaries & 0.0 & 0.0 & 0.0 & 0.0 & 0.0 & 0.0 \\
\hline FHIS & -12.8 & -44.3 & -13.1 & -13.1 & -23.4 & -12.8 \\
\hline Credit to the private sector & $5,008.5$ & $6,363.9$ & $7,711.4$ & $7,711.4$ & $10,957.8$ & $16,744.2$ \\
\hline Unclassified assets $1 /$ & $1,148.3$ & $1,819.9$ & $2,252.1$ & $2,658.0$ & $3,919.8$ & $3,141.7$ \\
\hline Medium- and long-term foreign liabilities & 71.4 & 312.5 & 539.8 & 678.5 & $1,116.6$ & $2,006.1$ \\
\hline Liabilities to central bank & 692.7 & 691.1 & 619.3 & 619.3 & 760.4 & 155.6 \\
\hline Liabilities to rest of banking system & 0.0 & 0.0 & $\mathbf{0 . 0}$ & 0.0 & 0.0 & 0.0 \\
\hline Liabilities to the private sector & $6,957.9$ & $9,200.8$ & $11,391.0$ & $11,854,4$ & $16,476.3$ & $23,627.6$ \\
\hline Liquid liabilities & $5,723.5$ & $7,540.2$ & $9,171.3$ & $9,634.7$ & $13,643.8$ & $19,742.1$ \\
\hline Sight deposits & $1,804.9$ & $2,472.3$ & $3,077.8$ & $3,077.8$ & $4,427.0$ & $5,606.1$ \\
\hline Quasi-money & $3,535.3$ & $4,378.7$ & $5,695.0$ & $6,154.6$ & $8,769.9$ & $13,608.3$ \\
\hline Domestic currency & $2,902.8$ & $3,183.7$ & $3,850.1$ & $3,850.1$ & $4,741.1$ & $8,389.0$ \\
\hline Time and savings deposits & $2,724.1$ & $3,033.5$ & $3,675.9$ & $3,675.9$ & $4,594.9$ & $8,237.9$ \\
\hline Specialized savings & 103.0 & 91.4 & 102.5 & 102.5 & 98.7 & 111.8 \\
\hline Other deposits & 75.7 & 58.8 & 71.7 & 71.7 & 47.5 & 39.3 \\
\hline Deposits in foreign currency & 632.5 & $1,195.0$ & $1,844.9$ & $2,304.5$ & $4,028.8$ & $5,219.3$ \\
\hline Bonds & 16.1 & 13.9 & 29.4 & 29.4 & 33.0 & 60.8 \\
\hline Other obligations & 367.2 & 675.3 & 369.1 & 372.9 & 413.9 & 466.9 \\
\hline Capital and surplus & $1,234.4$ & $1,660.6$ & $2,219.7$ & $2,219.7$ & $2,832.5$ & $3,885.5$ \\
\hline
\end{tabular}


Table 24. Honduras: Detailed Accounts of the Financial System

(In millions of lempiras)

\begin{tabular}{|c|c|c|c|c|c|c|}
\hline & \multicolumn{3}{|c|}{$1,10.34=U S \$ 1$} & \multicolumn{3}{|c|}{$\angle 13.0=$ US\$1 } \\
\hline & 1993 & 1994 & 1995 & 1995 & 1996 & 1997 \\
\hline \multicolumn{7}{|c|}{ III. Consolidated Development Banks } \\
\hline Net international reserves & 2.2 & 0.7 & 1.5 & 1.9 & 1.7 & 1.6 \\
\hline Foreign assets & 2.2 & 0.7 & 2.2 & 2.8 & 2.6 & 4.1 \\
\hline Short-term foreign liabilities & 0.0 & 0.0 & -0.7 & -0.9 & -0.9 & -2.5 \\
\hline Claims on central bank & 26.3 & 61.6 & 35.5 & 35.5 & 34.9 & 207.8 \\
\hline Cash in vaults & 10.8 & 13.5 & 14.5 & 14.5 & 13.9 & 20.8 \\
\hline Deposits & 15.5 & 48.1 & 19.5 & 19.5 & 17.9 & 168.4 \\
\hline CAMs & 0.0 & 0.0 & 1.5 & 1.5 & 3.1 & 18.6 \\
\hline Domestic assets & 581.6 & 635.3 & 628.6 & 664.3 & 687.4 & 445.5 \\
\hline Credit to public sector (net) & 28.5 & 9.3 & 15.5 & 15.5 & 32.3 & -152.0 \\
\hline Central government & -20.7 & -29.8 & -34.1 & -34.1 & -10.9 & -231.5 \\
\hline Credit & 7.2 & 6.9 & 7.7 & 7.7 & 35.4 & 219.7 \\
\hline Deposits & -27.9 & -36.7 & -41.8 & -41.8 & $-46,3$ & -451.2 \\
\hline Rest of public sector & 49.2 & 39.1 & 49.6 & 49.6 & 43.2 & 79.5 \\
\hline Credit & 107.1 & 104.7 & 111.9 & 111.9 & 114.2 & 173.1 \\
\hline Deposits & .57 .9 & -65.6 & -62.3 & -62.3 & -71.0 & -93.6 \\
\hline Government trust fund & -1.0 & -1.0 & -1.0 & -1.0 & -1.0 & -1.0 \\
\hline Official capital and surplus & -186.1 & -263.1 & -265.4 & -265.4 & -272.7 & $-1,514.7$ \\
\hline \multicolumn{7}{|l|}{ Credit to nonbank private } \\
\hline financial intermediaries & 0.0 & 0.0 & 0.0 & 0.0 & 0.0 & 0.0 \\
\hline Credit to the private sector & 143.1 & 163.1 & 192.2 & 192.2 & 237.6 & 330.2 \\
\hline FHIS & 0.0 & 0.0 & 0.0 & 0.0 & 0.0 & 0.0 \\
\hline Unclassified assets $1 /$ & 597.1 & $\mathbf{7 2 7 . 0}$ & 687.3 & 723.0 & 691.2 & $1,783.0$ \\
\hline Medium- and long-term foreign liabilities & 95.6 & 126.4 & 140.3 & 176.3 & 165.0 & 160.0 \\
\hline Liabilities to central bank & 371.4 & 407.2 & 330.1 & 330.1 & 321.4 & 164.7 \\
\hline Liabilities to rest of banking system & 0.0 & 0.0 & 0.0 & 0.0 & 0.0 & 0.0 \\
\hline Liabilities to the private sector & 143.1 & 164.0 & 195.2 & 195.3 & 237.6 & 330.2 \\
\hline Sight deposits & 13.9 & 15.5 & 13.9 & 13.9 & 17.0 & 31.6 \\
\hline Quasi-money & 76.2 & 77.5 & 89.4 & 89.5 & 99.3 & 117.4 \\
\hline Domestic currency & 74.9 & 77.1 & 89.0 & 89.0 & 97.5 & 115.0 \\
\hline Time and savings deposits & 73.3 & 75.1 & 85.3 & 85.3 & 91.9 & 106.2 \\
\hline Other deposits in local currency & 1.6 & 2.0 & 3.7 & 3.7 & 5.6 & 8.8 \\
\hline Deposits in foreign exchange & 1.3 & 0.4 & 0.4 & 0.5 & 1.8 & 2.4 \\
\hline Bonds & 0.5 & 1.0 & 1.0 & 1.0 & 0.3 & 17.4 \\
\hline Other obligations & 52.5 & 70.0 & 90.9 & 90.9 & 121.0 & 163.8 \\
\hline
\end{tabular}


Table 24. Honduras: Detailed Accounts of the Financial System

(In millions of lempiras)

\begin{tabular}{|c|c|c|c|c|c|c|}
\hline & \multicolumn{3}{|c|}{$L 10.34=$ USSI } & \multicolumn{3}{|c|}{$L 13.0=U S \$ 1$} \\
\hline & 1993 & 1994 & 1995 & 1995 & 1996 & 1997 \\
\hline \multicolumn{7}{|c|}{ IV. Specialized Savings Institutions } \\
\hline Net international reserves & 83.6 & 94.7 & 76.0 & 95.5 & 156.7 & 88.3 \\
\hline Foreign assets & 83.6 & 101.2 & 93.4 & 117.4 & 156.8 & 88.3 \\
\hline Short-term foreign liabilities & 0.0 & -6.5 & -17.4 & -21.9 & -0.1 & 0.0 \\
\hline Claims on central bank & 68.6 & 97.9 & 109.2 & 109.2 & 106.3 & 227.3 \\
\hline Cash in vaults & 11.7 & 15.4 & 18.9 & 18.9 & 21.5 & 19.4 \\
\hline Deposits & 37.4 & 62.0 & 69.7 & 69.7 & 55.2 & 105.3 \\
\hline FOVI bonds & 19.5 & 20.5 & 20.6 & 20.6 & 20.1 & 0.0 \\
\hline CAMs & 0.0 & 0.0 & 0.0 & 0.0 & 9.5 & 102.6 \\
\hline Domestic assets & 849.5 & 971.8 & $1,434.1$ & $1,444.0$ & $1,506.6$ & $1,250.7$ \\
\hline Credit to public sector (net) & -141.3 & -208.5 & .90 .4 & -90.4 & -17.8 & -104.8 \\
\hline Central government & 25.9 & 55.6 & 78.7 & 78.7 & 81.8 & 1.3 \\
\hline Credit & 27.9 & 60.7 & 85.7 & 85.7 & 81.8 & 1.3 \\
\hline Deposits & -2.0 & -5.1 & -7.0 & -7.0 & 0.0 & 0.0 \\
\hline Rest of public sector & -167.2 & -264.1 & -169.1 & -169.1 & -99.6 & -106.1 \\
\hline Credit & 2.5 & 2.5 & 3.6 & 3.6 & 0.0 & 0.0 \\
\hline Deposits & -169.7 & -266.6 & -172.7 & -172.7 & -99.6 & -106.1 \\
\hline Credit to rest of banking system & 0.0 & 0.0 & 0.0 & 0.0 & 0.0 & 0.0 \\
\hline Credit to the private sector & 858.9 & $1,033.8$ & $1,332.5$ & $1,332.5$ & $1,305.7$ & $1,439.1$ \\
\hline FHIS & -2.0 & -5.1 & -7.0 & -7.0 & 0.0 & 0.0 \\
\hline Unclassified assets $1 /$ & 133.9 & 151.6 & 199.0 & 208.9 & 218.7 & -83.6 \\
\hline Liabilities to central bank & 207.9 & 239.9 & 255.4 & 255.4 & 262.3 & 12.3 \\
\hline Liabilities to rest of banking system & 0.0 & 0.0 & 0.0 & 0.0 & 0.0 & 0.0 \\
\hline Liabilities to the private sector & 793.8 & 924.5 & $1,363.9$ & $1,393.3$ & $\mathbf{1 , 5 0 7 . 3}$ & $1,554.0$ \\
\hline Liquid liabilities & 678.6 & 781.1 & $1,180.8$ & $1,210.2$ & $1,282.9$ & $1,358.3$ \\
\hline Quasi-money & 587.6 & 654.1 & 827.1 & 856.5 & 945.1 & $1,001.8$ \\
\hline Deposits in domestic currency & 526.3 & 552.4 & 712.5 & 712.5 & 766.9 & 908.0 \\
\hline Time and savings deposits & 526.3 & 552.4 & 712.5 & 712.5 & 766.9 & 908.0 \\
\hline Deposits in foreign currency & 61.3 & 101.7 & 114.6 & 144.0 & 178.2 & 93.8 \\
\hline Other obligations & 91.0 & 127.0 & 353.7 & 353.7 & 337.8 & 356.5 \\
\hline Capital and surplus & 115.2 & 143.4 & 183.1 & 183.1 & 224.4 & 195.7 \\
\hline
\end{tabular}

V. Honduras: Consolidated Banking System

Net intemational reserves

Foreign assets

Net IMF position

Short-term foreign liabilities

$\begin{array}{rrrrrr}462.9 & \mathbf{6 4 0 . 2} & \mathbf{2 , 0 5 1 . 1} & \mathbf{2 , 5 7 7 . 9} & \mathbf{4 , 2 1 3 . 6} & \mathbf{8 , 6 6 4 . 2} \\ 2,223.3 & 3,078.6 & 4,416.4 & 5,550.9 & 5,916.3 & 11,242.9 \\ -1,266.3 & -1,099.9 & -1,079.7 & -1,357.0 & -759.2 & -601.7 \\ -494.1 & -1,338.5 & -1,285.6 & -1,616.0 & -943.5 & -1,977.0\end{array}$


Table 24. Honduras: Detailed Accounts of the Financial System

(In millions of lempiras)

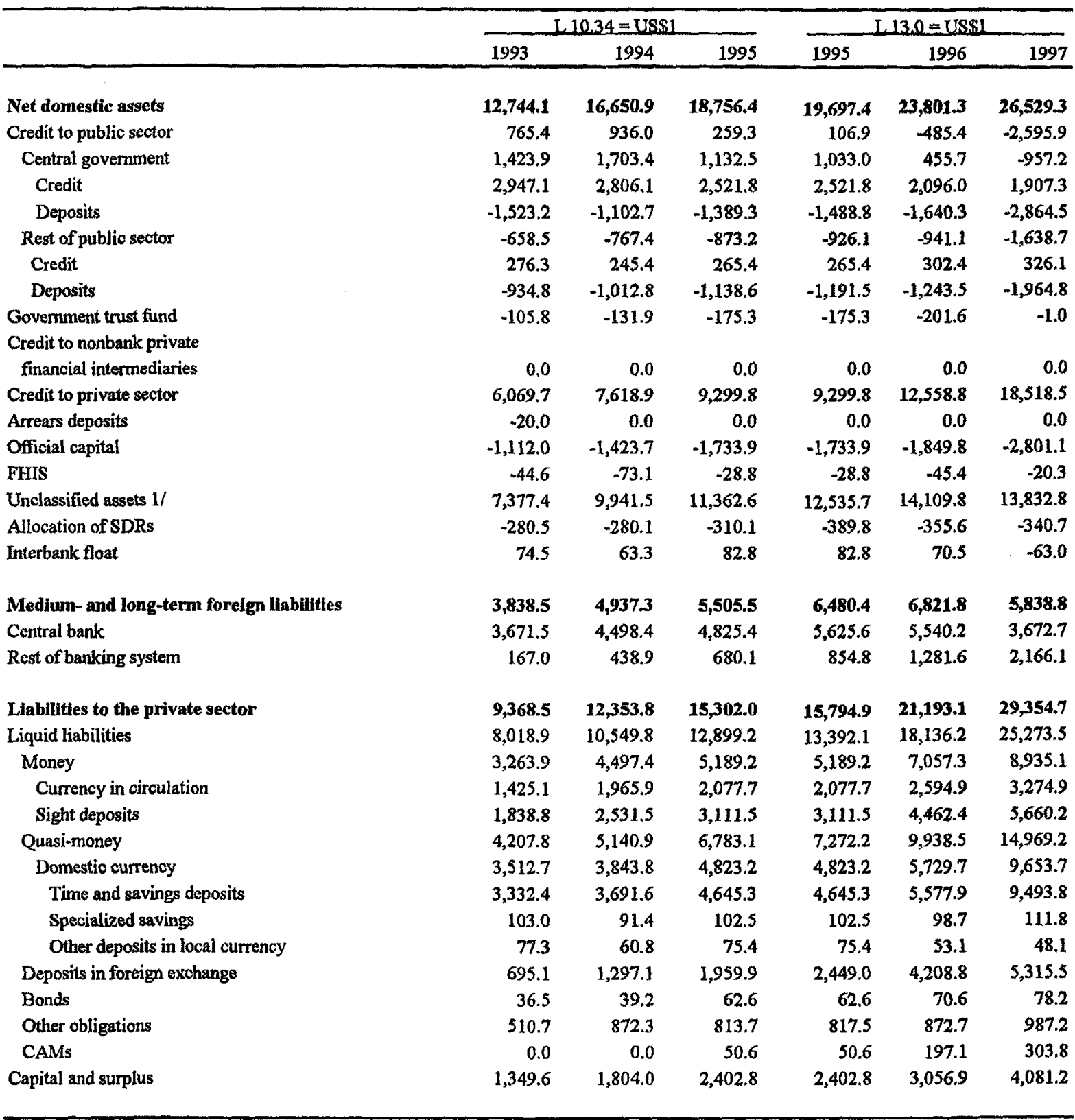

Source: Central Bank of Honduras.

1/Includes valuation adjustment.

2/ Housing Fund.

3/Open market operations. 
Table 25. Honduras: Destination of Banking System Credit to the Private Sector

\begin{tabular}{|c|c|c|c|c|c|}
\hline & 1993 & 1994 & 1995 & 1996 & $\begin{array}{l}\text { Pre!. } \\
1997\end{array}$ \\
\hline \multicolumn{6}{|c|}{ (In millions of lempiras) } \\
\hline Total & 5,970 & 7,450 & 9,022 & 12,106 & 14,492 \\
\hline Agriculture and related sectors & 1,199 & 1,480 & 1,576 & 1,938 & 2,208 \\
\hline Agriculture & 883 & 1,093 & 1,104 & 1,333 & 1,484 \\
\hline Coffee & 238 & 282 & 268 & 406 & 505 \\
\hline Cotton & 10 & 9 & 8 & 11 & 11 \\
\hline Basic grains & 174 & 212 & 203 & 239 & 285 \\
\hline Other & 462 & 590 & 626 & 677 & 683 \\
\hline Livestock & 251 & 348 & 403 & 484 & 528 \\
\hline Fishing & 65 & 38 & 68 & 122 & 197 \\
\hline Mining & 5 & 3 & 3 & 9 & 15 \\
\hline Manufacturing & 1,149 & 1,260 & 1,563 & 2,382 & 2,647 \\
\hline Transport and communications & 99 & 121 & 193 & 201 & 294 \\
\hline Construction and real estate & 1,076 & 1,328 & 1,755 & 2,114 & 2,629 \\
\hline Commerce & 1,664 & 2,124 & 2,786 & 3,923 & 4,762 \\
\hline Consumption & 380 & 445 & 527 & 702 & 876 \\
\hline Other & 399 & 689 & 620 & 837 & 1,061 \\
\hline \multicolumn{6}{|c|}{ (In percent of GDP) } \\
\hline Total & 26.3 & 25.8 & 24.0 & 25.3 & 23.6 \\
\hline Agriculture and related sectors & 5.3 & 5.1 & 4.2 & 4.1 & 3.6 \\
\hline Agriculture & 3.9 & 3.8 & 2.9 & 2.8 & 2.4 \\
\hline Coffee & 1.0 & 1.0 & 0.7 & 0.8 & 0.8 \\
\hline Cotton & 0.0 & 0.0 & 0.0 & 0.0 & 0.0 \\
\hline Basic grains & 0.8 & 0.7 & 0.5 & 0.5 & 0.5 \\
\hline Other & 2.0 & 2.0 & 1.7 & 1.4 & 1.1 \\
\hline Livestock & 1.1 & 1.2 & 1.1 & 1.0 & 0.9 \\
\hline Fishing & 0.3 & 0.1 & 0.2 & 0.3 & 0.3 \\
\hline Manufacturing & 0.0 & 0.0 & 0.0 & 0.0 & 0.0 \\
\hline Transport and communications & 5.1 & 4.4 & 4.2 & 5.0 & 4.3 \\
\hline Construction and real estate & 0.4 & 0.4 & 0.5 & 0.4 & 0.5 \\
\hline Commerce & 4.7 & 4.6 & 4.7 & 4.4 & 4.3 \\
\hline Consumption & 7.3 & 7.4 & 7.4 & 8.2 & 7.8 \\
\hline Other & 1.7 & 1.5 & 1.4 & 1.5 & 1.4 \\
\hline \multicolumn{6}{|c|}{ (In percent of total) } \\
\hline Total & 100.0 & 100.0 & 100.0 & 100.0 & 100.0 \\
\hline Agriculture and related sectors & 20.1 & 19.9 & 17.5 & 16.0 & 15.2 \\
\hline Agriculture & 14.8 & 14.7 & 12.2 & 11.0 & 10.2 \\
\hline Coffee & 4.0 & 3.8 & 3.0 & 3.4 & 3.5 \\
\hline Cotton & 0.2 & 0.1 & 0.1 & 0.1 & 0.1 \\
\hline Basic grains & 2.9 & 2.8 & 2.2 & 2.0 & 2.0 \\
\hline Other & 7.7 & 7.9 & 6.9 & 5.6 & 4.7 \\
\hline Livestock & 4.2 & 4.7 & 4.5 & 4.0 & 3.6 \\
\hline Fishing & 1.1 & 0.5 & 0.8 & 1.0 & 1.4 \\
\hline Mining & 0.1 & 0.0 & 0.0 & 0.1 & 0.1 \\
\hline Manufacturing & 19.2 & 16.9 & 17.3 & 19.7 & 18.3 \\
\hline Transport and communications & 1.7 & 1.6 & 2.1 & 1.7 & 2.0 \\
\hline Construction and real estate & 18.0 & 17.8 & 19.5 & 17.5 & 18.1 \\
\hline Commerce & 27.9 & 28.5 & 30.9 & 32.4 & 32.9 \\
\hline Consumption & 6.4 & 6.0 & 5,8 & 5.8 & 6.0 \\
\hline Other & 6.7 & 9.2 & 6.9 & 6.9 & 7.3 \\
\hline
\end{tabular}

Source: Central Bank of Honduras. 
Table 26. Honduras: Legal Reserve Requirements, End of Period

\begin{tabular}{lllll}
1993 & 1994 & 1995 & 1996 & 1997 \\
\hline
\end{tabular}

\section{Commercial and development banks}

Local currency deposits

Demand, saving, and time deposits $1 /$

Other deposits $1 / 2$ /

Housing

"Bonos de caja" 3/

Foreign currency deposits

Demand, saving, and time deposits 4/

Certicates of deposit 3/5/

"Free availability" deposits 4/5/

$\begin{array}{rrrrr}36.0 & 40.0 & 34.0 & 34.0 & 12.0 \\ 36.0 & 40.0 & 34.0 & 34.0 & 12.0 \\ 10.0 & 10.0 & 15.0 & 15.0 & 15.0 \\ 20.0 & 20.0 & 15.0 & 15.0 & 15.0 \\ & & & & \\ 100.0 & 100.0 & 100.0 & 100.0 & 12.0 \\ 100.0 & 100.0 & 100.0 & 100.0 & 12.0 \\ 100.0 & 100.0 & 100.0 & 100.0 & 12.0\end{array}$

Specialized saving institutions

Local currency deposits 6/7/

Foreign currency deposits $6 / 7 /$

$\begin{array}{rrrrr}17.0 & 21.0 & 21.0 & 21.0 & 12.0\end{array}$

$\begin{array}{lrrrr}100.0 & 100.0 & 100.0 & 100.0 & 12.0\end{array}$

Investment companies ("financieras")

Local currency deposits 6/8/

$\begin{array}{lllll}0.0 & 0.0 & 0.0 & 0.0 & 12.0\end{array}$

Special requirements for agricultural banks

Local currency deposits $9 /$

$20-30 \quad 20-30 \quad 20-30 \quad 20-30 \quad 20-30$

Source: Central Bank of Honduras.

1/ In addition, 19 percent as obligatory investment in official securities for 1997.

$2 /$ Savings certificates and certificates of deposit.

$3 /$ Long-term bonds issued to finance specific activities.

4/ In addition, 38 percent in foreign deposits and investments abroad for 1997.

5/ US\$25,000 minimum balance.

6/ Banks are authorized to hold these reserves in deposits abroad or in credits for exports.

$7 /$ In addition, 9 percent as obligatory investment in official securities for 1997.

8/ In addition, 3 percent as obligatory investment in official securities for 1997.

9/ For banks lending mainly to the agricultural sector. 
Table 27. Honduras: Distribution of Domestic Bonded Debt

(In millions of lempiras)

\begin{tabular}{|c|c|c|c|c|c|}
\hline & 1993 & 1994 & 1995 & 1996 & 1997 \\
\hline Central government bonds & $3,469.0$ & $3,587.4$ & $3,719.6$ & $3,875.6$ & $\mathbf{3 , 5 7 4 . 1}$ \\
\hline By holder: & $1,921.9$ & $1,434.9$ & $1,250.8$ & $1,138.3$ & 561.3 \\
\hline Central bank & 938.5 & $1,260.2$ & $1,177.6$ & 840.6 & 575.0 \\
\hline Commercial banks & 7.3 & 6.9 & 6.9 & 32.6 & 38.7 \\
\hline BANADESA & 27.9 & 60.7 & 85.7 & 81.4 & 1.3 \\
\hline Savings and loan associations & 0.0 & 0.0 & 120.8 & 142.7 & 28.9 \\
\hline Nonbank financial institutions & 46.2 & 52.6 & 178.8 & 399.4 & 683.8 \\
\hline IHSS & 248.6 & 481.1 & 445.9 & 606.8 & 458.4 \\
\hline Rest of public sector & 17.8 & 11.7 & 40.8 & 37.5 & 70.6 \\
\hline Insurance companies & 249.6 & 262.3 & 404.4 & 596.3 & $1,156.1$ \\
\hline Private sector & 11.2 & 17.0 & 7.9 & 0.0 & 0.0 \\
\hline \multicolumn{6}{|l|}{ International organizations } \\
\hline Local government bonds & 590.5 & 816.5 & $1,044.8$ & $1,175.7$ & $1,472.9$ \\
\hline By holder: & 63.3 & 59.5 & 63.1 & 50.6 & 116.4 \\
\hline Central bank & 80.2 & 85.1 & 92.3 & 154.7 & 148.4 \\
\hline Other credit institutions & 29.6 & 25.0 & 31.9 & 22.0 & 19.2 \\
\hline Rest of public sector & 417.4 & 646.9 & 857.5 & 852.1 & $1,100.1$ \\
\hline Central government & 0.0 & 0.0 & 0.0 & 96.3 & 88.8 \\
\hline \multicolumn{6}{|l|}{ Other public sector bonds } \\
\hline By holder: & $3,735.2$ & $4,547.8$ & $5,441.7$ & $7,635.0$ & $8,139.5$ \\
\hline Central bank & 101.0 & 77.5 & 86.9 & 81.5 & 69.6 \\
\hline Commercial banks & 4.1 & 2.7 & 3.6 & 0.0 & 0.0 \\
\hline BANADESA & 8.5 & 19.0 & 19.0 & 19.0 & 19.0 \\
\hline Central government & $3,620.4$ & $4,448.6$ & $5,295.8$ & $7,491.5$ & $8,023.9$ \\
\hline Private sector & 1.2 & 0.0 & 0.0 & 11.7 & 0.0 \\
\hline IHSS and INJUPEM & 0.0 & 0.0 & 36.4 & 31.3 & 27.0 \\
\hline By debtor: & $3,735.2$ & $4,547.8$ & $5,441.7$ & $7,635.0$ & $8,139.5$ \\
\hline ENEE & $2,269.2$ & $2,776.3$ & $3,506.3$ & $5,636.2$ & $6,501.2$ \\
\hline SANAA & 4.2 & 3.0 & 3.7 & 0.0 & 0.0 \\
\hline ENP & 302.7 & 391.2 & 419.6 & 454.1 & 228.6 \\
\hline HONDUTEL & 800.8 & 935.0 & 999.4 & $1,015.6$ & 964.1 \\
\hline Others & 358.3 & 442.3 & 512.7 & 529.1 & 445.6 \\
\hline
\end{tabular}

Source: Central Bank of Honduras. 
Table 28. Honduras: Weighted Interest Rates of the Banking System

(In percent, end of period)

\begin{tabular}{lllll}
1993 & 1994 & 1995 & 1996 & 1997 \\
\hline
\end{tabular}

I. Nominal Rates

\section{Lending rates}

Loans

Overdraft

Weighted average

\section{Deposit rates}

Saving deposits

Term deposits

Certificates

Annual inflation (CPI)

\section{4}

29.7

23.4

9.3

11.4

14.1

13.0

II. Real Rates 1/

\section{1 \\ 35.3}

30.9

\section{7}

11.1

15.9

28.9

\section{Lending rate}

\section{Loans}

Overdraft

Weighted average

Deposit rates

Saving deposits

Term deposits

Certificates
9.2

14.8

13.8

-3.3
-1.4
1.0
Source: Central Bank of Honduras.

1/ Nominal rates deflated by the estimated inflation.
28.4

35.6

37.8

10.1

12.6

17.1

23.8

20.2

10.0

17.4

19.5

12.6

19.3

21.7

14.8

39.6

$38.1 \quad 39.6$

$-2.2$

5.0

4.1

3.7

9.5

14.1

$\begin{array}{rrrr}-14.9 & -11.1 & -8.5 & -1.9 \\ -13.8 & -9.0 & -2.3 & 3.9 \\ -10.1 & -5.4 & -0.6 & 6.0\end{array}$

8.0

15.1

14.9

21.6 
Table 29. Honduras: Balance of Payments, 1993-97

(In millions of U.S. dollars; unless otherwise indicated)

\begin{tabular}{|c|c|c|c|c|c|}
\hline & 1993 & 1994 & 1995 & 1996 & $\begin{array}{l}\text { Prel. } \\
1997 \\
\end{array}$ \\
\hline Current account & -284 & -349 & -177 & -190 & -101 \\
\hline Trade balance & -397 & -382 & -273 & -336 & -429 \\
\hline Exports of goods (f.o.b.) & 878 & 1,017 & 1,298 & 1,423 & 1,536 \\
\hline Coffee & 125 & 200 & 350 & 279 & 327 \\
\hline Bananas and other fruit & 266 & 199 & 261 & 334 & 271 \\
\hline Other exports & 486 & 618 & 687 & 810 & 938 \\
\hline Imports of goods (f.o.b.) & $-1,275$ & $-1,399$ & $-1,571$ & $-1,759$ & $-1,964$ \\
\hline $\begin{array}{l}\text { Services } \\
\text { Of which }\end{array}$ & -105 & -178 & -168 & -130 & 16 \\
\hline Interest on external debt & -188 & -212 & -228 & -218 & -195 \\
\hline Value added from maquila industries & 114 & 125 & 163 & 204 & 308 \\
\hline Current transfers & 218 & 211 & 264 & 277 & 312 \\
\hline Capital accounts & 205 & 252 & 216 & 228 & 263 \\
\hline Foreign direct investment & 56 & 42 & 69 & 90 & 114 \\
\hline Portfolio nvestment $1 /$ & 0 & 0 & 0 & 0 & 54 \\
\hline Medium- and long-term loans & 294 & 112 & 74 & -5 & 39 \\
\hline Disbursements & 497 & 340 & 373 & 366 & 371 \\
\hline Amortizations & -203 & -228 & -299 & -371 & -332 \\
\hline Short-term loans & -145 & 99 & 72 & 142 & 56 \\
\hline Errors and Omissions & -125 & 94 & -43 & -121 & 62 \\
\hline Overall balance & -204 & -3 & -4 & -83 & 224 \\
\hline Change in reserves (increase -) & 117 & -23 & -90 & 13 & -308 \\
\hline Exceptional financing $2 /$ & 87 & 26 & 94 & 71 & 84 \\
\hline \multicolumn{6}{|l|}{ Memorandum items: } \\
\hline Current account (in percent of GDP) & -8.1 & -10.2 & -4.5 & -4.7 & -2.2 \\
\hline Overall balance (in percent of GDP) & -5.8 & -0.1 & -0.1 & -2.0 & 4.8 \\
\hline Gross reserves & 182 & 205 & 296 & 283 & 591 \\
\hline Reserves in months of imports $3 /$ & 1.5 & 1.5 & 2.0 & 1.7 & 3.2 \\
\hline Export growth & -5.9 & 15.9 & 27.6 & 9.6 & 7.9 \\
\hline Import growth & 1.0 & 9.7 & 12.3 & 11.9 & 11.7 \\
\hline Outstanding debt $4 /$ & 3,629 & 3,752 & 3,952 & 3,767 & 3,643 \\
\hline External debt arrears 5/ & 205 & 145 & 127 & 179 & 120 \\
\hline Debt to GDP ratio & 104 & 109 & 100 & 92 & 78 \\
\hline Debt service to exports ratio 6/ & 34.8 & 35.9 & 33.3 & 33.5 & 26.2 \\
\hline GDP & 3,506 & 3,428 & 3,961 & 4,080 & 4,699 \\
\hline Exchange Rate (period average) & 6.5 & 8.4 & 9.5 & 11.7 & 13.0 \\
\hline
\end{tabular}

Sources: Central Bank of Honduras; and Fund staff estimates.

1/ Data on portfolio investment is not available before 1996.

2/ Imports of goods and non factor services.

2/ Includes arrears to the Paris Club.

4/Medium and long-term public and publically guaranted external debt.

5/ Principal and interest arrears, includes arrears to the Paris Club.

6/ Exports of goods and non factor services. 
Table 30. Honduras: Exports by Product, 1993-97

\begin{tabular}{|c|c|c|c|c|c|}
\hline & 1993 & 1994 & 1995 & 1996 & $\begin{array}{l}\text { Prel. } \\
1997 \\
\end{array}$ \\
\hline \multicolumn{6}{|c|}{ (Value in millions of dollars, unit value in dollars) } \\
\hline Tradtional exports & 590.8 & 618.8 & 800.8 & 817.5 & 828.0 \\
\hline Coffee & 124.6 & 200.1 & 349.3 & 278.9 & 326.3 \\
\hline Volume ( 000 of quintals) & $2,225.0$ & $2,241.0$ & $2,343.0$ & $2,687.0$ & $2,246.0$ \\
\hline Unit Value (per $100 \mathrm{lb}$.) & 56.0 & 89.3 & 149.1 & 103.8 & 145.3 \\
\hline Bananas & 225.6 & 155.1 & 214.2 & 279.8 & 205.3 \\
\hline Volume (millions of $40 \mathrm{Ib}$. boxes) & 36.3 & 26.8 & 31.7 & 38.7 & 31.6 \\
\hline Unit Value (per box) & 6.2 & 5.8 & 6.8 & 7.2 & 6.5 \\
\hline Wood & 21.9 & 21.3 & 19.0 & 21.7 & 9.7 \\
\hline Volume ( 000 cubic meters) & 85.9 & 76.2 & 67.6 & 71.1 & $30 . \dot{4}$ \\
\hline Unit Value (per cubic meter) & 255.0 & 279.6 & 281.0 & 305.2 & 319.1 \\
\hline Beef & 39.6 & 39.0 & 13.0 & 11.0 & 11.0 \\
\hline Volume (millions of kilograms) & 16.9 & 16.2 & 6.0 & 5.8 & 5.5 \\
\hline Unit Value (per kilogram) & 2.3 & 2.4 & 2.2 & 1.8 & 2.0 \\
\hline Lead & 1.8 & 1.7 & 1.8 & 2.7 & 4.6 \\
\hline Volume (millions of Ibs.) & 7.8 & 6.3 & 5.8 & 7.4 & 13.6 \\
\hline Unit Value (per lb.) & 0.2 & 0.3 & 0.3 & 0.4 & 0.3 \\
\hline Zine & 23.0 & 21.1 & 27.1 & 25.7 & 53.8 \\
\hline Volume (millions of lbs.) & 58.5 & 51.4 & 63.2 & 61.5 & 96.6 \\
\hline Unit Value (per lb.) & 0.4 & 0.4 & 0.4 & 0.4 & 0.6 \\
\hline Silver & 3.5 & 4.4 & 5.5 & 4.7 & 6.5 \\
\hline Volume (millions troy ounces) & 0.9 & 0.9 & 1.1 & 0.9 & 1.4 \\
\hline Unit Value (per ounce) & 4.1 & 5.1 & 4.9 & 5.0 & 4.5 \\
\hline Shrimps & 112.4 & 133.6 & 124.5 & 143.2 & 164.1 \\
\hline Volume (millions of kilograms) & 10.2 & 10.3 & 9.2 & 10.7 & 11.4 \\
\hline Unit Value (per kilogram) & 11.0 & 13.0 & 13.5 & 13.4 & 14.4 \\
\hline Lobsters & 26.8 & 31.9 & 34.1 & 35.0 & 26.5 \\
\hline Volume (millions of kilograms) & 1.2 & 1.0 & 1.1 & 1.1 & 0.8 \\
\hline Unit Value (per kilogram) & 22.6 & 30.5 & 32.0 & 32.4 & 32.5 \\
\hline Sugar & 5.2 & 4.8 & 6.8 & 9.5 & 12.1 \\
\hline Volume (millions of kilograms) & 11.6 & 9.6 & 13.3 & 19.3 & 24.9 \\
\hline Unit Value (per kilogram) & 0.4 & 0.5 & 0.5 & 0.5 & 0.5 \\
\hline Tobacco & 6.4 & 5.8 & 5.5 & 5.3 & 8.1 \\
\hline Volume (millions of kilograms) & 2.9 & 2.6 & 2.4 & 2.3 & 2.7 \\
\hline Unit Value (per kilogram) & 2.2 & 2.3 & 2.3 & 2.3 & 3.0 \\
\hline Nontraditional exports & 271.0 & 346.7 & 419.4 & 503.3 & 614.8 \\
\hline Total exports, customs basis & 861.8 & 965.5 & $1,220.2$ & $1,320.8$ & $1,442.8$ \\
\hline Adjustments & 49.7 & 51.1 & 77.5 & 101.7 & 88.6 \\
\hline Unrecorded exports & 34.0 & 46.1 & 69.1 & 79.2 & 83.1 \\
\hline Re-exports & 15.7 & 5.0 & 5.0 & 5.0 & 5.0 \\
\hline Other & 0.0 & 0.0 & 3.4 & 17.5 & 0.5 \\
\hline Total exports, BOP basis & 911.5 & $1,016.6$ & $1,297.7$ & $1,422.5$ & $1, \mathbf{5 3 1 . 4}$ \\
\hline \multicolumn{6}{|c|}{ (In percent) } \\
\hline \multicolumn{6}{|l|}{ Memorandum items: } \\
\hline Traditional share, customs basis & 68.6 & 64.1 & 65.6 & 61.9 & 57.4 \\
\hline Nontraditional share, customs basis & 31.4 & 35.9 & 34.4 & 38.1 & 42.6 \\
\hline
\end{tabular}

Sources: Central Bank of Honduras; and Fund staff estimates. 
Table 31. Honduras: Economic Classification of Imports, 1993-97

\begin{tabular}{|c|c|c|c|c|c|}
\hline & 1993 & 1994 & 1995 & 1996 & $\begin{array}{l}\text { Prel. } \\
1997\end{array}$ \\
\hline \multicolumn{6}{|c|}{ (In millions of U.S. dollars) } \\
\hline Total imports, c.i.f. 1 / & $1,290.6$ & $1,460.3$ & $1,642.7$ & $1,840.0$ & $2,048.4$ \\
\hline Consumer goods & 278.1 & 318.8 & 356.8 & 400.2 & 455.7 \\
\hline Durables & 82.7 & 94.8 & 106.1 & 119.0 & 135.5 \\
\hline Nondurables & 195.4 & 224.0 & 250.7 & 281.2 & 320.2 \\
\hline Raw materials & 460.1 & 527.2 & 590.1 & 661.6 & 753.3 \\
\hline Agriculture & 95.8 & 109.7 & 122.8 & 137.5 & 156.5 \\
\hline Manufacturing & 364.3 & 417.5 & 467.3 & 524.1 & 596.8 \\
\hline Lubricants and fuels & 182.7 & 190.6 & 221.6 & 246.2 & $\mathbf{2 3 3 . 7}$ \\
\hline Capital goods & 344.0 & 393.6 & 440.7 & 494.1 & 561.6 \\
\hline Agriculture & 12.8 & 14.6 & 16.4 & 18.4 & 21.0 \\
\hline Manufacturing & 169.5 & 194.2 & 217.4 & 243.8 & 277.6 \\
\hline Transport & 123.7 & 141.8 & 158.7 & 178.0 & 202.7 \\
\hline Construction & 38.0 & 43.0 & 48.2 & 53.9 & 60.3 \\
\hline Other & 25.7 & 30.1 & 33.5 & 37.9 & 44.1 \\
\hline \multicolumn{6}{|c|}{ (In percent of total imports) } \\
\hline Consumer goods & 21.5 & 21.8 & 21.7 & 21.8 & 22.2 \\
\hline Raw material & 35.7 & 36.1 & 35.9 & 36.0 & 36.8 \\
\hline Lubricants and fuels & 14.2 & 13.1 & 13.5 & 13.4 & 11.4 \\
\hline Capital goods & 26.7 & 27.0 & 26.8 & 26.9 & 27.4 \\
\hline Other & 2.0 & 2.1 & 2.0 & 2.1 & 2.2 \\
\hline
\end{tabular}

Sources: Central Bank of Honduras; and Fund staff estimates.

1/ Customs basis. 
Table 32. Honduras: Foreign Trade Indices, 1993-97 1/

\begin{tabular}{|c|c|c|c|c|c|}
\hline & 1993 & 1994 & 1995 & 1996 & $\begin{array}{l}\text { Prel. } \\
1997 \\
\end{array}$ \\
\hline \multicolumn{6}{|c|}{ (Index 1987 = 100) } \\
\hline \multicolumn{6}{|l|}{ Exports, f.o.b. } \\
\hline Value & 122.0 & 132.7 & 170.3 & 185.5 & 194.8 \\
\hline Volume & 125.6 & 124.0 & 132.2 & 153.1 & 151.3 \\
\hline Unit value & 97.2 & 107.0 & 128.8 & 121.2 & 128.7 \\
\hline \multicolumn{6}{|l|}{ Imports, c.i.f. } \\
\hline Value & 126.6 & 146.7 & 165.1 & 186.4 & 198.8 \\
\hline Volume & 115.1 & 130.1 & 141.5 & 152.2 & 158.5 \\
\hline Unit value & 117.9 & 119.4 & 123.3 & 128.9 & 130.2 \\
\hline Terms of trade & 82.4 & 89.6 & 104.5 & 94.0 & 98.9 \\
\hline \multicolumn{6}{|c|}{ (Percentage change) } \\
\hline \multicolumn{6}{|l|}{ Exports, f.o.b. } \\
\hline Value & 2.4 & 8.8 & 28.3 & 9.0 & 5.0 \\
\hline Volume & -0.5 & -1.2 & 6.6 & 15.8 & -1.2 \\
\hline Unit value & 3.0 & 10.1 & 20.3 & -5.9 & 6.3 \\
\hline \multicolumn{6}{|l|}{ Imports, c.i.f. } \\
\hline Value & 17.5 & 15.9 & 12.5 & 12.9 & 6.6 \\
\hline Volume & 16.7 & 12.1 & 8.8 & 7.6 & 4.1 \\
\hline Unit value & 0.8 & 1.3 & 3.2 & 4.6 & 1.0 \\
\hline Terms of trade & 2.1 & 8.8 & 16.5 & -10.0 & 5.2 \\
\hline
\end{tabular}

Sources: Central Bank of Honduras; and Fund staff estimates.

1/ All indices are Laspeyres. 
Table 33. Honduras: Distribution of Exports, f.o.b. by Destination, 1993-96

(As percent of total)

\begin{tabular}{lrrrr}
\hline & 1993 & 1994 & 1995 & 1996 \\
\hline Total exports & 100.0 & $\mathbf{1 0 0 . 0}$ & $\mathbf{1 0 0 . 0}$ & $\mathbf{1 0 0 . 0}$ \\
United States & & & & \\
& $\mathbf{5 0 . 2}$ & $\mathbf{4 8 . 7}$ & $\mathbf{4 8 . 5}$ & $\mathbf{4 4 . 7}$ \\
Other Western Hemisphere & & & & \\
CACM countries 1) & 16.4 & $\mathbf{1 9 . 2}$ & $\mathbf{1 9 . 5}$ & $\mathbf{2 1 . 6}$ \\
Dominican Republic & 12.2 & 14.5 & 14.8 & $\mathbf{1 5 . 6}$ \\
Trinidad and Tobago & 0.1 & 0.1 & 0.1 & 0.6 \\
Venezuela & 0.2 & 0.3 & 0.3 & 0.0 \\
& 0.0 & 0.0 & 0.0 & 0.0 \\
Other & & & & \\
& 3.9 & 4.3 & 4.3 & $\mathbf{5 . 4}$ \\
Europe & & & & \\
Belgium & $\mathbf{2 7 . 9}$ & $\mathbf{2 4 . 6}$ & $\mathbf{2 4 . 6}$ & $\mathbf{2 4 . 5}$ \\
France & 6.5 & 4.3 & 3.5 & 4.8 \\
Germany & 1.0 & 1.2 & 1.2 & $\mathbf{1 . 0}$ \\
Italy & 11.6 & 6.2 & $\mathbf{8 . 6}$ & 6.5 \\
Netherlands & 1.0 & 1.7 & 1.7 & 2.2 \\
Spain & 1.0 & 1.9 & 1.9 & 2.3 \\
Other & 1.9 & 3.2 & 3.2 & 3.3 \\
& 4.9 & 6.1 & 4.5 & 4.4 \\
Other countries & & & & \\
Japan & 5.5 & 7.5 & $\mathbf{7 . 4}$ & $\mathbf{9 . 2}$ \\
Other & 2.2 & 3.2 & 3.2 & 2.8 \\
& 3.3 & 4.3 & 4.2 & 6.4 \\
\hline
\end{tabular}

Source: Central Bank of Honduras.

1/ Central American Common Market countries include Costa Rica, El Salvador, Guatemala, Honduras, and Nicaragua. 
Table 34. Honduras: Distribution of Imports, c.if., by Origin, 1993-96

(In percent of total)

\begin{tabular}{|c|c|c|c|c|}
\hline & 1993 & 1994 & 1995 & 1996 \\
\hline Total imports $1 /$ & 100.0 & 100.0 & 100.0 & 100.0 \\
\hline North America & 46.7 & 43.8 & 43.6 & 47.3 \\
\hline Canada & 1.1 & 0.9 & 0.7 & 0.7 \\
\hline United States & 45.6 & 42.9 & 42.9 & 46.6 \\
\hline Other Western Hemisphere & 35.6 & 34.5 & 34.9 & 36.3 \\
\hline CACM countries $2 /$ & 15.4 & 14.7 & 17.7 & 16.3 \\
\hline Brazil & 1.9 & 1.8 & 1.6 & 1.1 \\
\hline Colombia & 1.3 & 0.9 & 1.1 & 1.0 \\
\hline Mexico & 2.8 & 3.0 & 4.4 & 4.9 \\
\hline Trinidad and Tobago & 0.3 & 0.3 & 0.1 & 0.2 \\
\hline Venezuela & 0.9 & 0.9 & 1.3 & 1.6 \\
\hline Other & 13.0 & 12.9 & 8.7 & 11.2 \\
\hline Europe & 9.2 & 12.4 & 11.3 & 8.1 \\
\hline Belgium & 0.6 & 1.4 & 0.9 & 0.8 \\
\hline France & 0.7 & 0.6 & 0.3 & 1.1 \\
\hline Germany & 2.3 & 3.6 & 2.3 & 1.7 \\
\hline Italy & 1.0 & 0.7 & 0.7 & 0.6 \\
\hline Netherlands & 0.9 & 1.5 & 3.4 & 1.0 \\
\hline Spain & 0.6 & 1.8 & 1.6 & 1.1 \\
\hline United Kingdom & 0.8 & 0.7 & 0.4 & 0.5 \\
\hline Other & 2.3 & 2.1 & 1.7 & 1.3 \\
\hline Other countries & 8.5 & 9.3 & 10.2 & 8.3 \\
\hline Japan & 4.4 & 4.7 & 3.6 & 4.3 \\
\hline Other & 4.1 & 4.6 & 6.6 & 4.0 \\
\hline
\end{tabular}

Source: Central Bank of Honduras.

1/ Excludes adjustments for undervaluation and coverage.

2/ Central America Common Market countries include Costa Rica, El Salvador, Guatemala, Honduras and Nicaragua. 
Table 35. Honduras: Visible Trade with the

Central American Common Market, 1993-97

(In millions of U.S. dollars)

\begin{tabular}{|c|c|c|c|c|c|}
\hline & 1993 & 1994 & 1995 & 1996 & $\begin{array}{l}\text { Prel. } \\
1997 \\
\end{array}$ \\
\hline Exports, f.o.b. $1 /$ & 105.2 & 139.9 & 180.8 & 206.3 & 213.0 \\
\hline \multicolumn{6}{|l|}{ By destination } \\
\hline Costa Rica & 10.5 & 21.5 & 23.5 & 27.2 & 28.1 \\
\hline El Salvador & 32.7 & 43.5 & 51.9 & 59.1 & 61.0 \\
\hline Guatemala & 25.5 & 34.7 & 49.2 & 56.0 & 57.8 \\
\hline Nicaragua & 36.5 & 40.2 & 56.2 & 64.0 & 66.1 \\
\hline \multicolumn{6}{|l|}{ By commodity } \\
\hline Soap & 3.2 & 2.1 & 2.4 & $\cdots$ & ... \\
\hline Barbed wire & 1.0 & 0.2 & 0.2 & $\ldots$ & $\ldots$ \\
\hline Natural and vulcanized rubber & 0.8 & 0.3 & 0.3 & $\cdots$ & ... \\
\hline Edible corn starches & 0.7 & 0.4 & 0.5 & ... & $\ldots$ \\
\hline Plywood & 0.8 & 0.4 & 0.5 & $\cdots$ & $\cdots$ \\
\hline Fruit juices & 0.1 & 0.1 & 0.1 & $\cdots$ & ... \\
\hline Crown corks and metal stoppers & 0.7 & 0.2 & 0.2 & $\cdots$ & ... \\
\hline Other & 44.1 & 43.5 & 49.3 & $\cdots$ & $\cdots$ \\
\hline Imports, c.i.f. 1/ & 198.8 & 214.2 & 290.2 & 299.6 & 334.5 \\
\hline \multicolumn{6}{|l|}{ By origin } \\
\hline Costa Rica & 55.3 & 47.9 & 57.4 & 59.3 & 57.4 \\
\hline El Salvador & 50.3 & 59.0 & 83.6 & 89.4 & 115.1 \\
\hline Guatemala & 83.0 & 93.7 & 134.4 & 133.5 & 149.5 \\
\hline Nicaragua & 10.2 & 13.6 & 14.8 & 17.4 & 12.5 \\
\hline \multicolumn{6}{|l|}{ By commodity } \\
\hline Foodstuff, beverages, and tobacco & 25.2 & 24.7 & 35.4 & $\ldots$ & $\ldots$ \\
\hline Raw materials & 28.9 & 28.3 & 40.7 & $\ldots$ & $\ldots$ \\
\hline Chemicals & 47.2 & 46.2 & 66.4 & $\cdots$ & ... \\
\hline Manufactures & 53.3 & 52.2 & 75.0 & $\ldots$ & ... \\
\hline Capital goods & 12.6 & 12.3 & 17.7 & $\ldots$ & $\ldots$ \\
\hline
\end{tabular}

Source: Central Bank of Honduras.

1/ Excludes adjustments for undervaluation and coverage. 
Table 36. Honduras: Medium- and Long-term, Public and Publicly Guaranteed External Debt and Debt Service, 1993-97

\begin{tabular}{|c|c|c|c|c|c|}
\hline & 1993 & 1994 & 1995 & 1996 & $\begin{array}{l}\text { Prel. } \\
1997\end{array}$ \\
\hline \multicolumn{6}{|c|}{ (In millions of U.S. dollars) } \\
\hline Total outstanding (end of period) & $3,675.2$ & $3,751.7$ & 3,951.7 & $3,767.2$ & $3,642.5$ \\
\hline IMF & 119.2 & 109.2 & 97.9 & 57.8 & 46.1 \\
\hline Muttilaterals $1 /$ & $2,013.3$ & $2,174.6$ & $2,296.5$ & $2,245.2$ & $2,227.8$ \\
\hline Paris Club cxeditors & $1,073.0$ & $1,125.3$ & $1,227.3$ & $1,170.6$ & $1,073.7$ \\
\hline Other bilaterals & 256.7 & 173.1 & 201.9 & 195.8 & 225.0 \\
\hline Private creditors & 213.0 & 169.5 & 128.1 & 97.8 & 69.9 \\
\hline Disbursements & 509.6 & 308.3 & 381.9 & 301.1 & 247.7 \\
\hline IMF & 9.3 & 0.0 & 30.1 & 0.0 & 0.0 \\
\hline Multilaterals & 267.4 & 194.1 & 236.2 & 278.3 & 173.5 \\
\hline Paris Club creditors & 70.9 & 83.5 & 58.6 & 11.3 & 27.6 \\
\hline Other bilaterals & 8.1 & 30.7 & 57.0 & 11.5 & 46.6 \\
\hline Private creditors & 153.9 & 0.0 & 0.0 & 0.0 & 0.0 \\
\hline Debt service due before rescheduling & 425.7 & 419.4 & 468.3 & $\mathbf{5 3 2 . 2}$ & 372.9 \\
\hline IMF & 11.1 & 20.2 & 47.1 & 39.7 & 9.8 \\
\hline Multilaterals & 234.4 & 273.0 & 282.2 & 347.7 & 232.7 \\
\hline Paris Club creditors & 93.5 & 43.8 & 63.3 & 76.8 & 59.7 \\
\hline Other bilaterals & 47.7 & 39.1 & 22.0 & 30.4 & 34.5 \\
\hline Private creditors & 39.0 & 43.3 & 53.7 & 37.6 & 36.2 \\
\hline Debt service due after rescheduling & 359.8 & 384.8 & 422.7 & $\mathbf{5 0 5 . 9}$ & 376.4 \\
\hline MMF & 11.1 & 20.2 & 47.1 & 39.7 & 9.8 \\
\hline Multilaterals & 234.4 & 266.1 & 252.2 & 347.7 & 225.4 \\
\hline Paris Club creditors & 28.1 & 38.6 & 53.0 & 48.5 & 74.8 \\
\hline Other bilaterals & 47.2 & 19.1 & 20.5 & 32.4 & 31.7 \\
\hline Private creditors & 39.0 & 40.8 & 49.9 & 37.6 & 34.7 \\
\hline Debt service cash payments & 343.2 & 351.2 & 415.5 & 481.5 & 374.0 \\
\hline IMF & 11.1 & 20.2 & 47.0 & 39.7 & 9.8 \\
\hline Multilaterals & 229.0 & 241.1 & 251.4 & 340.7 & 225.4 \\
\hline Paris Club creditors & 21.7 & 34.3 & 52.6 & 44.4 & 74.6 \\
\hline Other bilaterals & 43.4 & 15.6 & 14.6 & 20.9 & 29.5 \\
\hline Private creditors & 38.0 & 40.0 & 49.9 & 35.8 & 34.7 \\
\hline Stock of arrears & 149.1 & 111.3 & 114.6 & 166.7 & 109.1 \\
\hline Multilaterals & 8.9 & 41.2 & 7.2 & 7.2 & 9.8 \\
\hline Paris Club creditors & 6.5 & 6.3 & 34.3 & 91.6 & 52.8 \\
\hline Other bilaterals & 98.3 & 41.5 & 38.5 & 33.9 & 33.4 \\
\hline Private creditors & 35.4 & 22.3 & 34.6 & 34.0 & 13.1 \\
\hline \multicolumn{6}{|c|}{ (In percent) } \\
\hline Debt to GDP ratio & 104.8 & 109.3 & 99.7 & 92.2 & 77.1 \\
\hline \multicolumn{6}{|l|}{ Debt service ratios $2 /$} \\
\hline Before rescheduling & 34,8 & 33.1 & 33.2 & 32.5 & 19.6 \\
\hline After rescheduling & 29.2 & 30.3 & 30.0 & 30.9 & 19.8 \\
\hline Cash payments & 28 & 27.7 & 29.5 & 29.4 & 19.7 \\
\hline
\end{tabular}

Sources: Central Bank of Honduras; and Fund staff estimates.

$1 /$ Including CABEI.

2/ Debt service in percent of export of goods and services. 
Table 37. Honduras: Stock of Arrears, 1994-97

(In millions of U.S. dollars)

\begin{tabular}{|c|c|c|c|c|}
\hline & 1994 & 1995 & 1996 & $\begin{array}{l}\text { Prel. } \\
1997\end{array}$ \\
\hline Stock of arrears & 145 & 127 & 179 & 120 \\
\hline Multilaterals & 41 & 7 & 7 & 10 \\
\hline Official bilateral & 82 & 85 & 138 & 97 \\
\hline Paris Club creditors & 6 & 34 & 92 & 53 \\
\hline Non-Paris Club & 75 & 51 & 47 & 44 \\
\hline Commercial & 22 & 35 & 34 & 13 \\
\hline Principal & 99 & 77 & 118 & 73 \\
\hline Multilaterals & 34 & 5 & 4 & 6 \\
\hline Official bilateral & 50 & 51 & 93 & 60 \\
\hline Paris Club creditors & 0 & 19 & 65 & 34 \\
\hline Non-Paris Club & 50 & 31 & 29 & 26 \\
\hline Commercial & 15 & 22 & 21 & 7 \\
\hline Interest & 46 & 50 & 61 & 47 \\
\hline Multilaterals & 7 & 3 & 3 & 4 \\
\hline Official bilateral & 32 & 35 & 45 & 37 \\
\hline Paris Club creditors & 6 & 15 & 27 & 19 \\
\hline Non-Paris Club & 26 & 20 & 18 & 18 \\
\hline Commercial & 7 & 13 & 13 & 7 \\
\hline
\end{tabular}

Source: Central Bank of Honduras. 
Table 38. Honduras: Nominal and Real Effective Exchange Rates, 1993-97 I/

(Period Averages; $1990=100)$

\begin{tabular}{|c|c|c|c|}
\hline Period & $\begin{array}{l}\text { Lempiras/ } \\
\text { U.S. Dollar } \\
\end{array}$ & $\begin{array}{c}\text { Nominal Effective } \\
\text { Exchange Rate Index 1/ }\end{array}$ & $\begin{array}{c}\text { Real Effective } \\
\text { Exchange Rate Index 1/ }\end{array}$ \\
\hline 1993 & 6.5 & 74.1 & 85.2 \\
\hline 1994 & 8.4 & 63.1 & 76.0 \\
\hline 1995 & 9.5 & 56.1 & 82.3 \\
\hline 1996 & 11.7 & 47.1 & 81.9 \\
\hline 1997 & 13.0 & 45.0 & 91.7 \\
\hline \multicolumn{4}{|l|}{1993} \\
\hline I & 5.8 & 78.5 & 90.1 \\
\hline II & 6.1 & 76.7 & 87.9 \\
\hline III & 6.9 & 70.5 & 81.7 \\
\hline IV & 7.1 & 70.8 & 80.9 \\
\hline \multicolumn{4}{|l|}{1994} \\
\hline I & 7.4 & 70.0 & 80.1 \\
\hline II & 8.1 & 65.0 & 76.5 \\
\hline III & 8.9 & 59.8 & 73.2 \\
\hline IV & 9.2 & 57.7 & 74.2 \\
\hline \multicolumn{4}{|l|}{1995} \\
\hline$I$ & 9.2 & 58.9 & 81.2 \\
\hline II & 9.2 & 56.9 & 82.1 \\
\hline III & 9.5 & 55.5 & 82.4 \\
\hline IV & 10.0 & 53.3 & 83.3 \\
\hline \multicolumn{4}{|l|}{1996} \\
\hline I & 10.7 & 50.9 & 81.9 \\
\hline II & 11.2 & 48.6 & 82.2 \\
\hline III & 12.2 & 44.8 & 80.5 \\
\hline IV & 12.6 & 44.0 & 83.2 \\
\hline \multicolumn{4}{|l|}{1997} \\
\hline I & 12.8 & 44.9 & 88.6 \\
\hline II & 13.0 & 44.6 & 90.0 \\
\hline III & 13.1 & 45.1 & 93.3 \\
\hline IV & 13.1 & 45.4 & 94.9 \\
\hline \multicolumn{4}{|l|}{1997} \\
\hline January & 12.9 & 43.8 & 85.7 \\
\hline February & 12.7 & 45.3 & 89.1 \\
\hline March & 12.8 & 45.6 & 91.0 \\
\hline April & 12.8 & 45.1 & 90.3 \\
\hline May & 13.1 & 44.4 & 89.5 \\
\hline June & 13.1 & 44.3 & 90.3 \\
\hline July & 13.1 & 44.8 & 92.1 \\
\hline August & 13.1 & 45.4 & 93.9 \\
\hline September & 13.1 & 45.1 & 94.0 \\
\hline October & 13.1 & 50.0 & 93.6 \\
\hline November & 13.1 & 45.2 & 94.4 \\
\hline December & 13.1 & 46.0 & 96.6 \\
\hline
\end{tabular}

Sources; Central Bank of Honduras; and the Information Notice System.

1/ A decline in the index reflects depreciation. 